

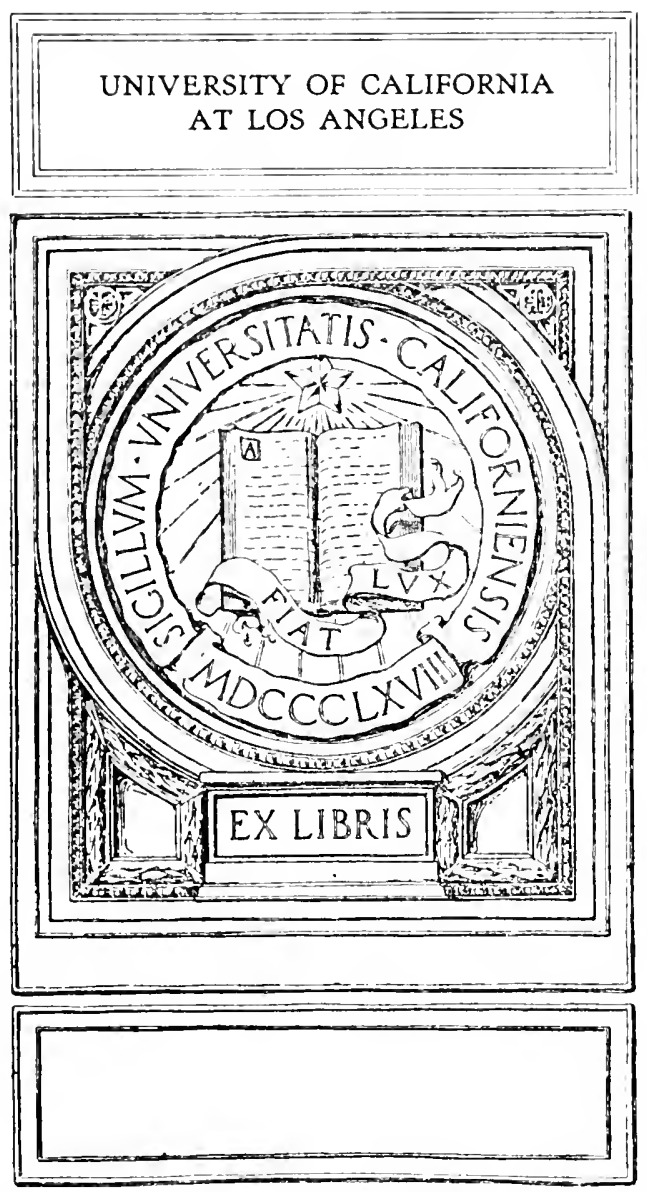


$$
\text { " }
$$ 



\title{
Bibliography of the Works of DR JOHN DONNE \\ Dean of St Paul's
}

\author{
by \\ Geoffrey Keynes
}

\section{CAMBRIDGE:}

Printed for the Baskerville Club

and sold by Bernard Quaritch, London, W.

I 9 I 4 
$a^{\prime \prime 2}$

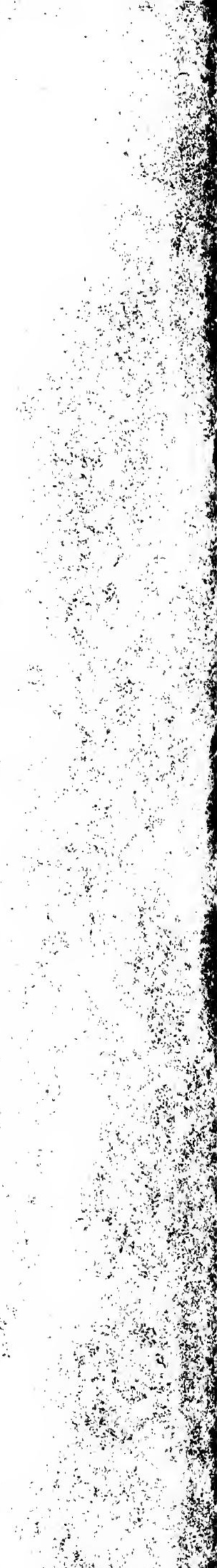




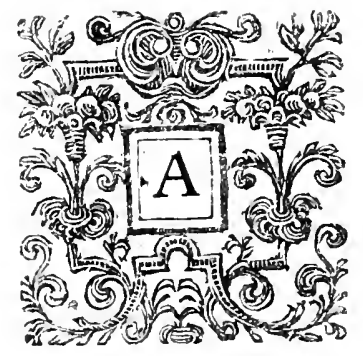




\title{
THE BASKERVILLE CLUB
}

\author{
F. J. H. Jenkinson, President
}

H. G. Aldis

T. D. Barlow

A. T. Bartholomew, Secretary

F. G. M. Beck

J. B. Bilderbeck

F. K. Bliss

J. Charrington

J. Clay

A. F. Cole

A. Esdaile

W. M. Fletcher

M. D. Forbes

S. Gaselee

E. Ph. Goldschmidt

C. A. Gordon

Edmund Gosse

W. W. Greg

Henry Jackson
M. R. James

C. H. Jenkinson

G. L. Keynes

J. M. Keynes

W. R. M. Lamb

N. McLean

G. P. Mander

H. F. Moule

A. G. W. Murray

H. B. Noble

J. W. Reynolds

C. Sayle

R. S. Straus

A. A. Tilley

T. A. Walker

C. Whibley

P. W. Wood

C. N. S. Woolf 


\section{JOHN DONNE}

He wes of ftature moderately tall; of a Araight and equally proportioned body, to which all bis words and actions gave an unexpressible addition of comelinefse.

His afpect was cheerfull, and fuch as gave a filent teftimony of a cleere knowing foule, and of a confcience at peace with it Jelfe.

His melting eye fherwed be bad a foft beart, full of noble pity, of too brave a spirit to offer injuries, and too much a Chriftian, not to pardon them in others.

His fancie was un-imitable bigh, equalled by bis great wit, both being made ufefull by a commanding judgement.

His mind was liberall, and unwearied in the Search of knowledge, with which bis vigorous foule is now fatiffed, and employed in a continuall praife of that God that firft breatbed it into bis active body, which once was a Temple of the holy Ghost, and is now become a small quantity of Chriftian duft. But I sball see it re-inanimated. 



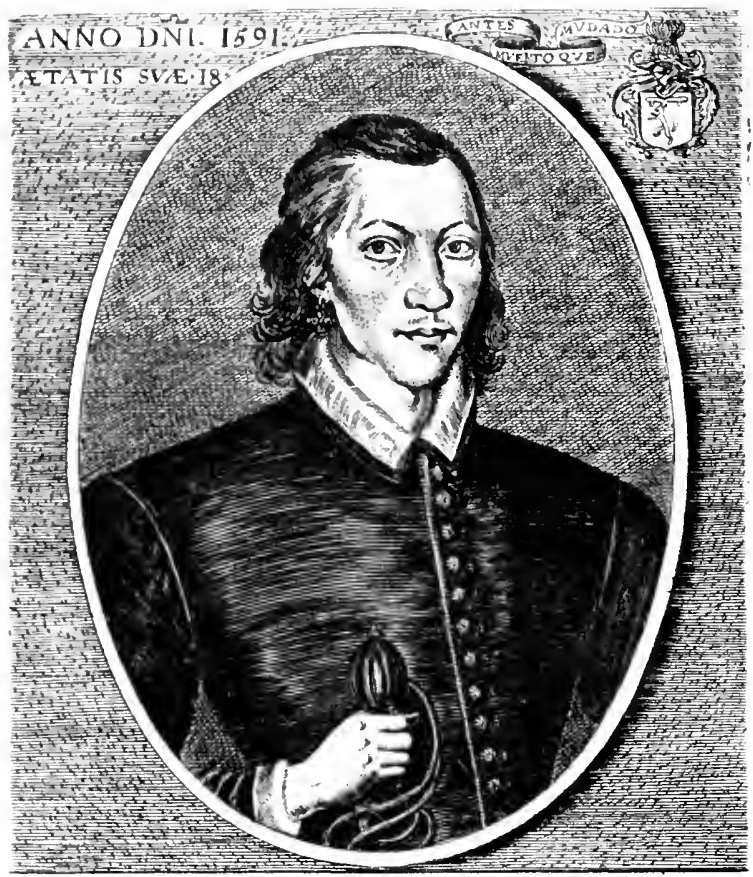

This unas for gouth, Strmoth, Mirtn, and wit that Jime Troft count their aoderu fac; but t'uns not thine. Thine was tha fater yeares, so mucr refind From youths Drojse, Mirtn, or wit; as tin jure mind Anought (fire the Inacfs) nothing but the Prai? of thy Creator, in thoo fast, Gost Dayes. W'imes this Booke, (tín Embleme) which Geains witr Love; Gut ondes, roith Sighes, e Jearos for Pins. Will: Marshall frupsit.

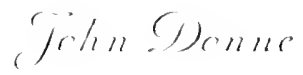


Bibliography of the Works of

\title{
DR JOHN DONNE \\ Dean of St Paul's
}

\author{
by \\ Geoffrey Keynes
}

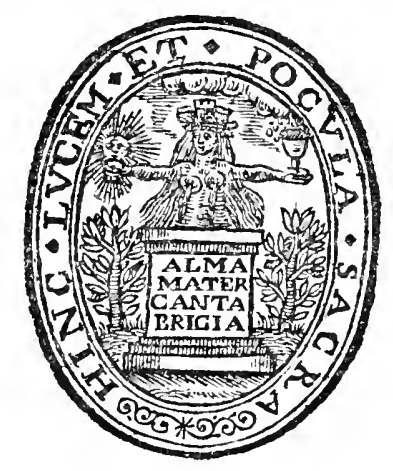

\section{CAMBRIDGE:}

Printed for the Baskerville Club

and sold by Bernard Quaritch, London, W.

I9I 4 
$-303$ 


\section{GENERAL PREFACE}

No complete bibliography of Donne's works has previously been undertaken, and I feel confident that this book will be found of use by students of Donne's writings and by collectors of the original editions. I hope it may also be of value to all those who take more than a casual interest in Donne, and to bibliographers in general.

The material that I have used has been drawn mainly from the following sources: the chief public libraries in England and Scotland; the college libraries in Cambridge and Oxford; some of the cathedral libraries; and the private collections of members of the Baskerville Club. In the case of some rare books I have also recorded copies in other private collections in England and America, and a few from sale catalogues. I have myself seen almost all the copies recorded as having been found in London, Cambridge, and Oxford.

The two books, which have been of greater assistance to me than any others, are $\mathrm{Mr}$ Edmund Gosse's Life and Letters of Fobn Donne and Professor Grierson's edition of Domne's poems; I am also indebted to these authors for encouragement and help.

I wish to record here my gratitude to all those Librarians whose courtesy has rendered available to me so much of the material upon which this bibliography is founded; also to Miss Henrietta C. Bartlett of New York for her kindness in examining on my behalf those editions of Donne's works which are in the libraries of $\mathrm{Mr}$ Beverly Chew and $\mathrm{Mr}$ W. A. White.

The proof sheets have been read by Mr Francis Jenkinson, Mr Charles Sayle, Mr A. T. Bartholomew, Mr Cosmo Gordon, and Mr H. G. Aldis, and I am deeply grateful to these gentlemen for the numerous and useful suggestions which they have made. I am indebted to Miss E. M. Spearing for some important corrections in the section dealing with the Sermons.

The system of bibliographical description that I have used is, I hope, clear enough to need no explanation.

\section{GEOFFREY KEYNES}

LONDON

May, 1914. 


\section{CONTENTS}

PROSE WORKS

PAGE

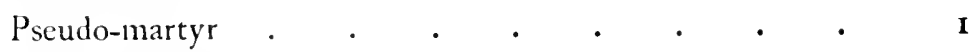

Conclave Ignati $\quad . \quad$. $\quad . \quad$. $\quad . \quad$. 7

Sermons . $\quad . \quad$. $\quad . \quad$. $\quad . \quad$. 17

Devotions . $\quad . \quad$. $\quad . \quad$. $\quad . \quad$. 39

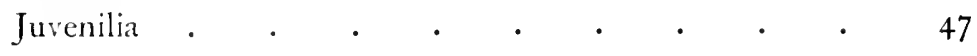

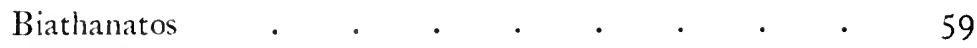

Essays in Divinity . . . . . . . . . 67

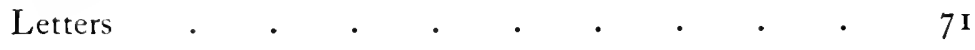

POETICAL WORKS

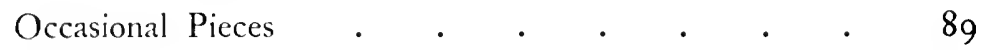

First and Second Anniversaries . . . . . . 93

Collected Poems . . . . . . . . . . 103

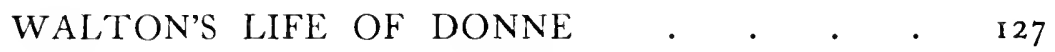

BIOGRAPHY AND CRITICISM • • • • I 35

APPENDICES

I. Works by John Donne, D.C.L. . . . 145

II. Works by John Done . . . . . I I I

III. Books from Donne's library . . . . 154

IV. A book dedicated to Donne . . . . 156

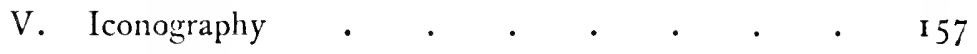

List of Printers and Publishers, i607-i719 . . I6I

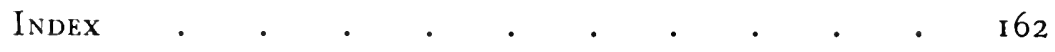




\section{ILLUSTRATIONS}

\section{REPRODUCTIONS OF ENGRAVINGS}

I. Donne at the age of 18 (frontispiece to Pocms, I635).

Frontispiece

2. Donne in his shroud (frontispiece to Death's Duell, I632) . To face p. 27

3. Donne at the age of 42 (frontispiece to So Sermons, 1640). To face $p .33$

4. Donne's effigy (frontispiece to Devotions, 1634). . . To face p. 45

5. Pseudo-martyr, 1610 . . . . . . . . . . 5

6. Conclave Ignati, $1611,12^{\circ} \cdot .+.+. \quad . \quad$. 10

7. Conclave Ignati, I6I I, $4^{\circ}$. . . . . . . . $\quad$ I3

8. Death's Duell, 1632 . . . . . . . . . . 27

9. Six Sermons, 1634 . . . . . . . . . . 30

ı. Devotions, 1624 . . . . . . . . . . 43

I1. Juvenilia, 1633 . . . . . . . . . . 53

12. Biathanatos, 1644 . . . . . . . . . . 64

13. An Anatomy of the World, 1611. . . . . . . 97

14. The First Anniversary, 1625 . . . . . . . 99

15. The Second Anniversary, 1625 . . . . . . . IOI

I6. Walton's Life of Donne, 1658 . . . . . . . I3I

All the plates and blocks for the illustrations have been prepared by Messrs Emery Walker, Ltd., with the exception of the blocks for nos. 13-15 above, for which the Baskerville Club is indebted to the Delegates of the Clarendon Press. 


\section{ABBREVIATIONS}

Alford: The Works of John Donne. With a memoir of his life. By Henry Alford. London, i 839. 6 vols. [no. 33.]

Chambers: Poems of John Domne. Edited by E. K. Chambers. London, 1896.2 vols. [no. 100.]

Gosse : The Life and Letters of John Donne. By Edmund Gosse. London, I 899. 2 vols. [no. 126.]

Grierson: The Poems of John Donne. Edited by H. J. C. Grierson. Oxford, 1912. 2 vols. [no. 105.]

ALE: Advocates' Library, Edinburgh.

BLO : Bodleian Library, Oxford.

BM : British Museum.

ULC: University Library, Cambridge. 
PSEUDO-MARTYR

J. D. 



\section{PSEUDO-MARTYR}

\section{Bibliographical Preface}

The Pseudo-martyr belongs to the year I609, and was the second controversial work composed by Donne, though it was the first to be printed. According to Walton (Life, 1658, pp. 37-38) it was written by Donne at the command of King James, and was completed within six weeks. Mr Gosse points out, however, that this story is probably untrue. In his dedication Donne writes_- Of my boldnesse in this addresse, I most humbly beseech your Maiestie, to admit this excuse, that having observed, how much your Maiestie had vouchsafed to descend to a conversation with your Subiects, by way of your Bookes, I also conceiv'd an ambition, of ascending to your presence, by the same way"; it is unlikely that he would have written in this manner, had the book been composed expressly at the King's command. Further, a passage in the Advertisement shews that the Table of the Chapters had been in circulation for a considerable period before the completion of the book, and though the last two chapters mentioned in it were never written, Donne still allowed their headings to appear in the Table. "I have abstained," he writes, "from handling the two last Chapters upon divers reasons; whereof one is, that these Heads having beene caried about, many moneths, and thereby quarrelled by some, and desired by others, I was willing to give the Booke a hasty dispatch, that it might cost no man much time, either in expecting before it came, or in reading, when it was come. But a more principall reason was, that since the two last Chapters depend upon one another, and have a mutuall Relation, I was not 
willing to undertake one, till I might persevere through both. And from the last chapter it became me to abstaine, till I might understand their purposes, who were formerly engaged in the same businesse."

The greater part of the work is now chiefly of historical interest, and the book has never been reprinted; but the Preface to the Priestes and Jesuits contains some interesting autobiographical passages. A more extended account of the book will be found in Gosse, i. 245-254.

Donne's book was perhaps too closely reasoned and too calmly written to admit of a reply being easily framed, and none was published until I6I3; in that year was published a work by Thomas Fitzherbert in which a long reply to the Pseudo-martyr is to be found. This book, which is not recorded by Donne's biographers, has the following title :

A supplement to the difcufion of $M$. D. Barlowes anfwere To the Iudgment of a Catbolike Englishman $\mathcal{E}^{2}$ c. interrupted by the death of the Author F. Robert Persons of the Society of Iefus...And By the way is briefly cenfured M. Iohn Dunnes Booke, intituled Pfeudo-martyr...By F. T...Permiffu Superiorum. M.DC.XIII.

The answer to Pseudo-martyr occupies pp. 86-i Io (Chap. II $\$ 330-78$ ). The Pseudo-martyr is also referred to by John Boys, Dean of Canterbury, in his work-An expofition of all the principall foriptures ved in our Englifh Liturgie. Together with a reafon why the Church did chufe the fame... London...1622. "I will not meddle," he writes (p. 277), "with the cobwebs of learning in the Schoole, which have more wit then Art, yet more Art then use; nor with the distorted and idle glosses of the Canonists : he that list may burthen his memory with a shipfull of their fooleries, accuratly collected by the penner of Pseudomartyr, cap. Io." 


\section{P S E
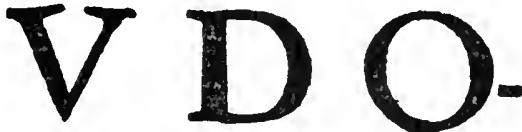 \\ MARTYR \\ Wherein \\ O V T OF CERTAINE} Propofitions and Gradations, This

Conclufion is euicted.

THAT THOSE WHICH ARE of the Romane Religion in this Kingdome, may and ought to take the Oath of Allegcasce.

DEVT.32.15.

But be that jhould haue beesp ypright, when be waxed fatte, Jpurred with bis beele: Thou art fat, thou art groffe, thou art laden with fatneffe.

$$
\text { IO B. II.5. }
$$

But ob that God rovild fpeake and open his lips againft thee, that he might. Then tbee the fecrets of wifedome, bow thou baft deferued dosble according to right.

2. C H R 0.28.22.

In the time of his tribulation, did be yet trespaf $\int_{e}$ more agalnft tbe Lord, for be facrificed unto the gods of Damafcus, whicb plagued birn.

\section{O N D O N}

Printed by W. Stansby for Walter Burre. I 6 I 0 .

Title-page of no. 1. 
I PSEUDO-MARTYR.

$4^{\circ} .1610$

Title (within double lines): Pfeudo-martyr. Wherein out of certaine Propofitions and Gradations, This Conclufion is euicted. That thofe which are of the Romane Religion in this Kingdome, may and ought to take the Oath of Allegeance. [rule]

DEVT. 32. 15.

But he that flould haue beene spright, when he waxed fatte, Jpurned with his helle: Thou art fat, thou art grofe, thou art laden with fatnele.

Iов. 11.5 .

But oh that God would Jpenke and open his lips againft thee, that he might fhew thee the fecrets of wifedome, how thou haft deforued double according to right.

2. Chro. 28.22.

In the time of his tribulation, did he yet trefpale more againft the Lord, for he facrificed onto the gods of Damajcus, which plagued him.

[rule] London Printed by W. Stansby for Walter Burre. I610.

Collation: $\mathrm{A}^{+} \mathrm{I}^{2} \mathrm{~B}-\mathrm{Z} \mathrm{Aa}-\mathrm{Zz}$ Aaa-Ggg ${ }^{4} \mathrm{Hhh}^{2} ; 216$ leaves.

Contents: A I title; $\mathrm{A}_{2}-\mathrm{A}_{3}$ dedication To the High and Migbtie Prince Iames... signed Iobn Donne; A $A$ Table of the Chapters; II $-\tau_{2} a$ An advertifement to the Reader; $\mathbb{I}_{2 b}$ errata; $\mathrm{BI}_{\mathrm{I}}-\mathrm{E} 2$ A Preface to The Prieftes and Iefuits, and to their difciples in this Kingdome; $\mathrm{E}_{3}-\mathrm{Hhh2}$ (pp. I-392) text.

Note: The Table of the Cbapters gives the headings of fourteen chapters; the book, however, contains only twelve of these, the last two never having been written for reasons which the author explains in the Advertisement (see my preface). The book is very carelessly printed and contains a large number of misprints in addition to those more serious ones recorded by Donne in the errata. The pagination of sheets $Y$ and $\mathrm{Aa}$ is faulty; $133,136,137,140,154$ are printed $121,124,125,128,156$.

Copies : BM, ULC (2), BLO, ALE.

Cambridge Colleges: Caius, Emmanuel, Magdalene, Queens', St John's (2), Trinity (3).

Oxford Colleges: Corpus Christi, New College, St John's.

Salisbury Cathedral Library.

Edmund Gosse (presentation copy to Rowland Woodward with a Spanish sentence in Donne's handwriting on title-page); G. L. Keynes. 
CONCLAVE IGNATI 



\section{CONCLAVE IGNATI}

\section{Bibliographical Preface}

The Conclave Ignati or Ignatius his Conclave, the third of Donne's controversial writings, was composed and published in i61 i. Neither of the Latin editions is dated, but Mr Gosse has shewn conclusively (i. 257) from internal evidence that the work belongs to that year. It is a vigorous and amusing satire, but except in Mr Gosse's book (loc. cit.) it has received very little notice from Donne's biographers. Two Latin editions were printed in I6II. One of these, a duodecimo, has no imprint, and may have been printed in London or abroad; it is extremely rare, only two copies being known to me. The other is a thin quarto, which was printed at Hanau; this, too, is very rare and is recorded here for the first time. The first edition of the English version of the satire was also published in I6II, and three more editions were issued in I626, I634, and I635. The English version was reprinted with the date I 653 with the Juvenilia in the volume of $165^{2}$, and the Latin version was reprinted in I680; since that date Donne's satire has not been reprinted in either form.

The earlier issues of the Conclave Ignati were anonymous, but in the three English editions issued after Donne's death his name appears on the title-page; it is omitted, however, from the Latin reprint of I 680. Donne himself, as he implies in the preface, regarded the book as too undignified a production to be publicly acknowledged, but doubtless the authorship was well known to his contemporaries. In the volume of 1652 the editor, John Donne the younger, describes the Ignatius his Conclave on the general title-page as "lately found among his [the author's] own Papers," and appears to ignore the previous issues; but this was evidently only for purposes of sale. 
Conclaue Fgnati:

Siuc

EIVS IN N V.

PERIS INFERNI

C O M I T I I $S$

Futbronifatio.

Vbivaria

De Iefiutarum Indole,

De nouo infernocreando,

De Ecclefin Lunatica inflituenda, per Satyram congeltafunt.

Accelsit or Apologias pro Iefuitis.

Omnia

Dusobus Angelis Aduerfariis, gui Conifftorio Papali, \& Collegio Sorbonx prafi. dent,dedicati.

Title-page of no. 2. 
Title: [rule] Conclaue Ignati : [rule] Siue eius in nuperis inferni comitiis Inthronifatio. Vbi varia

De Iefuitarum Indole,

De nouo inferno creando,

De Ecclefia Lunatica inftituenda,

per Satyram congefta funt. Accefsit $\mathcal{E}$ Apologia pro Iefuitis. Omnia Duobus Angelis Aduerfariis, qui Confiftorio Papali, E Collegio Sorbonæ præfident, dedicata.

Collation: $\mathrm{A}-\mathrm{D}^{12} \mathrm{E}^{6} ; 54$ leaves.

Contents: A I title; A2-A3 Typographus Lectori; $\mathrm{A}_{4}-\mathrm{E}_{2}$ (pp. I-94) text, addressed: Angelis tutelaribus, Conffjorio Papali, E Collegio Sorbonce Prafidentibus; $\mathrm{E}_{3}-\mathrm{E}_{5}$ a Apologia pro Iefuitis; E5b errata, headed: Lectori. Iefuitarum Damonem credo operce infediffe: unde aliàs tot errata? Noftra autem bic corrigimus: Jed quando Iefuite fua?; E6 blank.

Note: The ornament used on $\mathrm{A}_{4}$ and $\mathrm{E}_{3}$ of this book is the same as is found on the title-page and other leaves of no. 3, which was probably printed at Hanau (see note); it is possible, therefore, that the present edition was printed there, but the same ornament was also used by London printers.

Copies: BM, BLO.

3 CONCLAVE IGNATI.

$4^{\circ} \cdot[\mathrm{I} 6 \mathrm{II}]$

Title: Conclaue Ignati : Siue eius in nuperis inferni comitiis inthronifatio. Vbi varia

De Iefuitarum Indole,

De nouo inferno creando,

De Ecclefia Lunatica inftituẽda,

per Satyram congefta funt. Acceffit et apologia pro Iefuitis. Omnia Duobus Angelis Aduerfariis, qui Confiftorio Papali, E Collegio Sorbonæ præfident, dedicata. [ornament]

Collation: $\mathrm{A}-\mathrm{D}^{4} \mathrm{E}^{2}$; 18 leaves.

Contents: A I (pp. I-2) title; $\mathrm{A}_{2}$ (pp. 3-4) Typograpbus Lectori; $\mathrm{A}_{3}-\mathrm{E}_{\mathbf{1}} b$ (pp. 5-34) text ; Er $b-\mathrm{E} 2 a$ (pp. 34-35) Apologia pro lefuitis (errata, headed Lectori, etc., at bottom of $\mathrm{E}_{2} a$ ); $\mathrm{E}_{2} b$ blank. 
Note: This edition does not seem to have been noticed elsewhere. Each of the only two copies known to me is bound up with other tracts which were printed at Hanau, apud Thomam Villerianum ${ }^{1}$, and it is probable, for typographical reasons, that this edition of the Conclave Ignati was issued from the same press.

Copies : ULC (2, Acton collection).

4 IGNATIUS HIS CONCLAVE. 120. I6I I Title (within single line): Ignatius his Conclaue: or His Inthronifation in a late Election in Hell: Wherein many things are mingled by way of Satyr ; Concerning

The Difpofition of Iefuits,

The Creation of a new Hell,

The eftablifhing of a Church in the Moone.

There is alfo added an Apology for Iefuites. All dedicated to the two Aduerfary Angels, which are Protectors of the Papall Confiftory, and of the Colledge of Sorbon. Tranflated out of Latine.

London, Printed by N. O. for Richard More, and are to be fold at his fhop in S. Dunftones Church-yard. I6II.

Collation: $\mathrm{A}-\mathrm{G}^{12} ; 8+$ leaves.

Contents: A I blank; A2 title; $\mathrm{A}_{3}-\mathrm{A}_{5}$ The printer to the Reader; $\mathrm{A}_{6}-\mathrm{G}_{5}$ a (pp. I-143) text; $\mathrm{G}_{5} b$ blank; G6-G 7 An Apology for Iefuites; G8a errata; G8b-Gi 2 blank.

Note: Printed by Nicholas Okes (1606-c. 1635).

Copies: BM, ULC.

5 IGNATIUS HIS CONCLAVE.

120. 16 II

Title (within ornamental border): Ignatius his Conclaue : or His Inthronifation in a late Election in Hell: Wherein many things are mingled by way of Satyr ; Concerning

The Difpofition of fuits,

The Creation of a new Hell,

The eftablifhing of a Church in the Moone.

1 This imprint may possibly be fictitious, but there is good evidence for accepting it as genuine. 


\section{CONCLAVE IGNATI.}

\section{Siue}

\section{EIVS IN NVPERIS INFER I COMITIIS I NTHRONISATIO.}

Vbi varia

De Iefuitarum Indole,

De nouo inferno creando, DeEcclefia Lunaticainftituêda, per Satyram congefta funt.

ACCESSIT ET A POLOGIA PRO IES VITIS.

\section{Omnia}

Duobus Angelis Adwerfariis, qui Conffftorio Papal, E Collegio Sorbone prafident, dedicata.

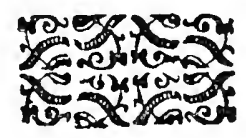

Title-page of no. 3 . 
There is also added an Apology for Iefuites. All dedicated to the two Aduerfary Angels, which are Protectors of the Papall Confiftory, and of the Colledge of Sorbon. [rule]

London, Printed by N. O. for Richard More, and are to be fold at his thop in S. Dunstones Church-yard. I6II.

Note: A title-page as above is to be found inserted at the end of the BM copy of the preceding edition, but I have not seen a copy of the book in which it actually forms the title. It is probable that this was an earlier form of the title-page, in which fuits was misprinted for Iefuits in 1.4 and the words Tranflated out of Latine were omitted; but that the corrections having been made while the book was in the press most or all of the copies with the misprinted title-page were destroyed ${ }^{1}$. 'This edition of the book is rare in any form.

6 IGNATIUS HIS CONCLAVE.

I $2^{\circ}$. I6 II

Title: Ignatius his Conclaue : or The Enthronifation of Loyola in Hell. Imprinted At London in 16 I I.

Collation, Contents: As in no. 4.

Note: Another issue of no. 4 with cancel title.

Copy: Library of W. A. White, Esq., New York (examined for me by Miss Henrietta C. Bartlett).

7 IGNATIUS HIS CONCLAVE.

I $2^{\circ} .1626$

Title (within single line) : Ignatius his Conclave : or, His Inthronifation in a late Election in Hell :... [etc. as in no. 4] [rule]

London, Printed by M. F. for Richard More, and are to be fold at his thop in S. Dunftans Church-yard. 1626.

Collation: $\mathrm{A}-\mathrm{G}^{12} ; 84$ leaves.

Contents: AI-A2 blank; $\mathrm{A}_{3}$ title; $\mathrm{A}_{4}-\mathrm{A} 6$ The printer to the Reader; $\mathrm{A}_{7}-\mathrm{G} 6$ a (pp. I-I 43) text; G6b blank; G7-G8 An Apology for Iefuites; G9-Gi2 blank. Note: Printed by Miles Fletcher (161 1-1664).

Copies: BM, ULC.

King's College, Cambridge.

1 I have seen an unbound copy of no. 4 , in which the title-page was clearly not a cancel. 
IGNATIUS HIS CONCLAVE.

I $2^{\circ} .1634$

Title (within single line): Ignatius his Conclave: or, His Inthronifation in a late Election in Hell : Wherin many things are mingled by way of Satyr. Concerning

The Difpofition of Iefuites,

The Creation of a new Hell,

The eftablifhing of a Church in the Moone.

There is alfo added an Apology for Iefuites. All dedicated to the two adverfary Angels, which are protectors of the Papall Confiltory, and of the Colledge of Sorbon. By Iohn Donne, Doctor of Divinitie, and late Deane of Saint Pauls. [rule]

London, Printed for Iohn Marriott, and are to be fold by W. Sheares at the Harrow in Britains Burfie. I634.

Collation: $\mathrm{A}-\mathrm{F}^{12} ; 7^{2}$ leaves.

Contents: AI title; $\mathrm{A}_{2}-\mathrm{A}_{3} a$ The printer to the Reader; $\mathrm{A}_{3} b$ blank; $\mathrm{A}_{4}-\mathrm{F}_{\mathrm{I}} a$ (pp. I-I35) text; FI Ib-FI2 An Apologie for Iefuites.

Copies: BM, ULC, BLO.

Peterborough Cathedral Library.

\section{IGNATIUS HIS CONCLAVE.}

I $2^{\circ} \cdot 1635$

Title (within single line) : Ignatius his Conclave :... [etc. as in no. 8].

London,... I 635 .

Collation, Contents: As in no. 8.

Note: This issue consists of the same sheets as no. 8 with the date altered on the title-page, which is, however, not a cancel. Presumably the alteration was made while the book was in the press.

Copies: BLO.

Corpus Christi College, Oxford.

Peterborough Cathedral Library.

Edmund Gosse. 
Subtitle (within single line) : Ignatius his conclave : or, His Inthronifation in a late Election in Hell. Wherein many Things are mingled by way of satyr. Concerning

The difpofition of Jefuites.

The Creation of a new Hell.

The eftablifhing of a Church in the Moon.

There is alfo added an Apologie for Jesuites. All dedicated to the Two adverfary Angels, which are Protectors of the Papall Confiftory, and of the Colledge of Sorbon. [rule] By John Donne, Doctor of Divinity, and late Dean of Saint Pauls. [rule]

Printed at London, 1653 .

Collation, Contents: See no. 45, Paradoxes, Problems, etc., 1652.

I I CONCLAVE IGNATII.

8. $\quad 1680$

Title (within double lines): Lucii Cornelii Europæi Monarchia Solipsorum. Et Conclave Ignatii : sive Ejus in Nuperis Inferni Comitiis Inthronifatio. [rule] Londini, Proftat venalis apud Jacobum Collins, in Vico vulgò vocato Efiex-Street. I 680 .

Collation: $\mathrm{A}-\mathrm{O}^{\mathrm{s}}$; i 12 leaves.

Contents: A I title; A2 Timotcus Cursantius Leoni Allatio S.; A3-I2 (pp. I-I28), Monarcbia Solipsorum; $\mathrm{I}_{3}-\mathrm{I}_{4}$ Syllabus; $\mathrm{I}_{5}$ subtitle to Conclave Ignatii; I6-I7 Typographus Lectori; I8-O5 (pp. I-76) Conclave Ignatii; O6 (pp. 77-78) Apologia pro Fesuitis; $\mathrm{O}_{7}$ Some Books printed for Fames Collins; $\mathrm{O} 8$ blank.

Note: This book usually occurs bound up with a later work, Papifmus Regice Poteftatis Everfor, dated I68I, the general title-page being as follows:

Papifmus Regice Poteftatis Everfor. Reverendus admodum Epifcopus Lincoln. Anglicè foripfit. Robertus Grovius S.T.B. De Anglicano Latinum fecit ....Quibus ab alio adjunguntur Monarchia Solipforum et Conclave Ignatii. Londini,... apud Facobum Collins, Es Samuelem Lowndes,...1682.

Copies: BM, BLO.

Salisbury Cathedral Library (2). 
SERMONS

J. D. 



\section{SERMONS}

\section{Bibliographical Preface}

Donne had taken orders at the instigation of King James in January, I6I5; he was appointed Dean of St Paul's in November, I62 I, and in this capacity became one of the most celebrated preachers of his time. The earliest of his sermons that has survived with a date was preached on April 30, 1615; his last sermon was preached before King Charles on February 25, I63I, and was soon afterwards printed under the title of Deatb's duell ${ }^{1}$.

Six of Donne's sermons were printed during his lifetime between I 622 and 1627 ; seven more, including the Death's duell, were printed soon after his death, and later, in I640, 1649 , and I 660, three folio volumes containing I 54 sermons were issued by his son, John Donne, D.C.L." These volumes included the seven posthumous sermons just mentioned, but the remaining I 47, with the exception of one which had been issued anonymously in I 638, had not been printed before. Other sermons have survived in MS. ${ }^{3}$ but have not yet been printed. Those sermons which were printed by Donne during his lifetime were also collected by him in successive volumes containing Three Sermons (1623), Foure Sermons (1625), and Five Sermons

1 This is stated by Walton to have been preached on the first Sunday in Lent. Miss E. M. Spearing has pointed out to me that this fell on Feb. 25 in $163 \frac{0}{1}$, and not, as stated by Mr Gosse, on Feb. 12.

2 See pp. $1+6-147$ of present work.

${ }^{3}$ A collection, which was in the library of the late Prof. Dowden, is now in the possession of a member of the Baskerville Club, Mr Wilfred Merton. 
(1626); these volumes were not reprints in the ordinary sense, but consisted of the sheets of the individual sermons as first issued bound up together, with a general title-page substituted for the title-page of the first sermon. The sermons also occur bound up together by their original owners; one such volume in the library of Pembroke College, Cambridge, containing all the sermons issued in quarto up to 1634 , was evidently collected by Izaak Walton, whose autograph appears in it in two places'. The great majority of the sermons were reprinted by Alford in his edition of $\mathrm{I} 839$.

The literary value of Donne's sermons, particularly in relation to his poetry, has only recently been fully realised ${ }^{2}$; after he had taken orders he wrote but few poems, and his sermons consequently became his chief means of expression. According to Walton he did not read his sermons from the pulpit, but committed them to memory and wrote them out afterwards in a form ready for publication ${ }^{3}$. An idea of the manner in which he recast his sermons may be gained by comparing the text of the sermon printed by Milbourne in 1638 from an unauthorised copy with that of the same sermon as it was printed in the folio of 1660 . Walton's description of Donne's delivery of the first sermon, which he preached before the King, must be accepted as a true estimate of his great power as a preacher. "Preaching the word so," Walton writes, "as shewed his own heart was possest with those very thoughts, and joyes that he laboured to distil into others. A Preacher in earnest, weeping sometimes for his Auditory, sometimes with them; alwaies preaching to himself like an Angell from a cloud, but in none; carrying some, as St. Paul was, to Heaven in holy raptures, and inticing others by a sacred art and Courtship to amend their lives; here picturing a vice so as to make it ugly to those that practised it; and a vertue so, as to make it be loved even by those that lov'd it not, and all this with a most particular grace and an unexpressible addition of comelinesse." (Walton's Life of Donne, 1658, pp. 47-48.)

1 See nos. 26 and 27.

'See Grierson, ii. liii and passim; and Miss Spearing in The Modern Language Review, Jan. 19 I 2 .

${ }^{3}$ See also p. I 46 of present work. 
SERMON ON JUDGES, xx. I5.

$4^{\circ} .1622$

Title (within double lines): A fermon vpon the xv. verfse of the xx. chapter of the Booke of Iudges Wherein occafion was iuftly taken for the Publication of fome Reafons, which his Sacred Maieftie had beene pleafed to giue, of thofe Directions for Preachers, which he had formerly fent forth. Preached at the Croffe the I $5^{\text {th. }}$ of September. I622. By Iohn Donne, Doctor of Diuinitie and Deane of Saint Pauls, London. And now by commandement of his Maieftie publifhed, as it was then preached. [rule]

London Printed by William Stansby for Thomas Iones, and are to be fold at his thop in the Strand at the blacke Rauen, neere vnto Saint Clements Church. I622.

Collation: $\mathrm{A}-\mathrm{I}^{4} \mathrm{~K}^{2} ; 3^{8}$ leaves.

Contents: A I blank; $\mathrm{A}_{2}$ title; $\mathrm{A}_{3}-\mathrm{A}_{4} a$ dedication To the right bonourable, George, Marqueffe of Buckingham; $\mathrm{A}_{4} b$ errata ; $\mathrm{B}_{\mathrm{I}}-\mathrm{K}_{2}$ (pp. I-68) text.

Note: The reference to the text given on the title-page of this book is a mistake for Judges, v. 20; this was not corrected until the third issue of the sermon (see no. I4). Not reprinted in the folios; but it is printed by Alford, vi. $19 \mathbf{I}$.

Copies: BM.

Edmund Gosse ; G. L. Keynes.

SERMON ON JUDGES, xx. 15. $4^{\circ} \cdot \quad 1622$

Title (within double lines): A fermon vpon the $\mathrm{xv}$. verfe of the $\mathrm{xx}$. chapter of the Booke of Iudges...

London Printed by William Stansby for Thomas Iones,... I622.

Collation: $\mathrm{A}-\mathrm{I}^{4} \mathrm{~K}^{2} ; 3^{8}$ leaves.

Contents: A I blank; A2 title; $\mathrm{A}_{3}-\mathrm{A}_{4} a$ dedication; $\mathrm{A}_{4} b$ blank; $\mathrm{B}_{\mathrm{I}}-\mathrm{K}_{2}$ (pp. I-68) text.

Note: A second issue of no. 12 . The errata noted on $\mathrm{A}_{4} b$ of the first issue have been corrected, but the misprint on the title-page remains as before.

Copy: BLO.

SERMON ON JUDGES, v. 20.

$4^{\circ} \cdot \quad 1622$

Title (within double lines): A fermon vpon the $\mathrm{xx}$. verfe of the $\mathrm{v}$. chapter of the Booke of Iudges... 
London, Printed for Thomas Jones, and are to bee fold at his Shop in the Strand, at the blacke Rauen, neere vnto Saint Clements Church. I 622 .

Collation: $\mathrm{A}^{2} \mathrm{~B}-\mathrm{I}^{4} \mathrm{~K}^{\mathrm{n}} ; 36$ leaves.

Contents: A I title; A2 dedication; $\mathrm{B}_{\mathrm{I}}-\mathrm{K}_{2}$ (pp. I-68) text.

Note: In this, the third, issue of the sermon the sheets $\mathrm{B}-\mathrm{K}$ are the same as in no. I3, but a new first quire of two leaves has been substituted for the original AI-4. The text is now given correctly on the title-page, which also shews other minor alterations.

Copies: BM.

Pembroke College, Cambridge.

G. L. Keynes.

I 5 SERMON ON ACTS, i. 8. $4^{\circ} \cdot 1622$

Title (within double lines): A fermon vpon the viri. verfe of the i. chapter of the Acts of the Aportles. Preach'd To the Honourable Company of the Virginian Plantation. I $3^{\circ}$. Nouemb. 1622. By Iohn Donne Deane of $\mathrm{S}^{\text {t. Pauls, London. [rule] }}$

London. Printed by A. Mat: for Thomas Iones and are to [be] fold at his Shop in the Strand, at the blacke Rauen, neere vnto Saint Clements Church. 1622 .

Collation: $\mathrm{A}-\mathrm{G}^{4} ; 28$ leaves.

Contents: A I blank; A2 title; A3 dedication To the bonourable company of the Virginian Plantation; $\mathrm{A}_{4}-\mathrm{G}_{4} a$ (pp. I-49) text (errata at bottom of $\mathrm{G}_{4} a$ ); $\mathrm{G}_{4} b$ blank.

Note: Issued again in 1624 (see no. I 8), but not reprinted in the folios. It is given by Alford, vi. 225. This and several of the succeeding sermons were printed by Augustin Matthewes (1619-1653).

Copies: BM, ULC.

I6 ENCÆNIA.

$4^{\circ} \cdot 1623$

Title (within double lines): Encænia. The feart of dedication. Celebrated At Lincolnes Inne, in a Sermon there vpon Afcenfion day, i623. At the Dedication of a new Chappell there, Confecrated by the Right Reuerend Father in God, the Bifhop of London. [rule] Preached by Iohn Donne, Deane of $\mathrm{S}^{\mathrm{t}}$. Pauls. [rule] 
London, Printed by Aug. Mat. for Thomas Iones, and are to bee fold at his Shop in the Strand, at the blacke Rauen, neere vnto Saint Clements Church. I623.

Collation: $\mathrm{A}^{4} \mathrm{~B}-\mathrm{F}^{4} \mathrm{G}^{2} ; 26$ leaves.

Contents: A I title; A2 dedication To the Mafters of the Bench, and the reft of the Honourable Societie of Lincolnes Inne; $\mathrm{A}_{3}$ The Prayer before the Sermon; [ $\mathrm{A}_{4} \mathrm{can}-$ celled] ; BI-Gia (pp. I-4I) text; Gi $b-\mathrm{G} 2$ blank.

Note: On John, x. 22. Not reprinted in the folios, or by Alford. $A_{4}$ has been cancelled in all the copies known to me, including those bound up in the Three Sermons, etc. Notwithstanding the fact that the catchword on $A_{3} b$ corresponds with the first word on $\mathrm{B} a$, it is evident from the sewing that the signatures $\mathrm{A}_{2}$ and $A_{3}$ have not been misprinted; presumably the cancelled leaf was a blank.

Copies: BM, ULC, BLO.

Cambridge Colleges: Pembroke, St John's.

Merton College, Oxford.

Edmund Gosse; G. L. Keynes.

THREE SERMONS.

$4^{\circ} \cdot \quad 1623$

Title (within double lines): Three fermons vpon speciall occasions. [rule] Preached by Iohn Donne Deane of St. Pauls London. [ornament between rules]

London, Printed for Thomas Iones, and are to [be] fold at his Shop in the Strand at the Blacke Rauen neere St. Clements Church. I623.

Collation: $\mathrm{A}-\mathrm{I}^{4} \mathrm{~K}^{2}, \mathrm{~A}-\mathrm{G}^{4}, \mathrm{~A}-\mathrm{F}^{4} \mathrm{G}^{2} ; 38+28+26=92$ leaves.

Contents: A I general title; $\mathrm{A}_{2}-\mathrm{K}_{2}$ A fermon vpon the $x v$ verfe of the $x x$ chapter of the Booke of Iudges, 1622 (as in no. 13); $\mathrm{A}-\mathrm{G}_{4}$ A fermon vpon the viiil. verfe of the i. chapter of the Acts of the Apoftles, 1622 (as in no. 15); $\mathrm{AI}_{\mathrm{I}}-\mathrm{G} 2$ Encenia, 1623 (as in no. 16).

Note: This volume consists of nos. 13, 15, and 16, bound up together, with a general title-page as above substituted for the original A I blank of no. 13.

Copy: Trinity College, Cambridge.

SERMON ON ACTS, i. 8. $4^{\circ} \cdot 1624$ Title (within double lines): A fermon vpon the eighth verfe of the firt Chapter Of The Acts Of The Apoftles. Preached To the Honourable Company 
of the Virginian Plantation, I3. Nouemb. I622. By Iohn Donne Deane of Saint Pauls, London. [rule]

London, Printed for Thomas lones. I 624.

Collation: $\mathrm{A}-\mathrm{G}^{4} ; 28$ leaves.

Contents: A I blank; A2 title; $A_{3}$ introductory address $\mathcal{T}_{0}$ the bonourable companie of the Virginian Plantation; $\mathrm{A}_{4}-\mathrm{G}_{4} a$ (pp. I-49) text; $\mathrm{G}_{4} b$ blank.

Note: A reprint of no. 15 , in which the errata (noted on $\mathrm{G}_{4} a$ of the first issue) have been corrected. Most of the copies known to me occur in the Foure fermons of 1625 and the Fiue fermons of 1626 . In four of these by an error of the printer the first page of the text and the second page of the introductory address have been transposed. In the fifth example, which occurs in Mr Edmund Gosse's copy of the Fiue Jermons, these pages are in their right positions.

Copy : Pembroke College, Cambridge.

Title (within double lines): The firft fermon preached to King Charles, At Saint Iames : $3^{\circ}$. April. I625. [rule] By lohn Donne, Deane of Saint Pauls, London. [rule]

London, Printed by A. M. for Thomas Iones, and are to bee fold at his Shop at the Signe of the Blacke Rauen in the Strand. I625.

Collation: $\mathrm{A}-\mathrm{H}^{4} ; 32$ leaves.

Contents: Ar blank; A2 title; $\mathrm{A}_{3}-\mathrm{H}_{4} a$ (pp. I-59) text (errata at bottom of $\mathrm{H}_{4} a$ ); $\mathrm{H}_{4} 6$ blank.

Note: On Psalm xi. 3. Not reprinted in the folios, or by Alford.

Copies: BM, BLO.

Cambridge Colleges: Emmanuel, Pembroke, St John's, Trinity.

Edmund Gosse.

20 FOURE SERMONS.

Title (within double lines): Foure fermons vpon fpeciall occasions.

(Viz.)

I. A Sermon preached at Pauls Crofie.

2. To the Honourable, the Virginia Company.

3. At the Consecration of Lincolnes Inne Chappell.

4. The first Sermon preached to K. Charles at St. Iames, I625. 
[rule] By Iohn: Donne. Deane of St. Pauls, London. [rule]

London, Printed for Thomas Iones, and are to be fold at his Shop in the

Strand at the Blacke Rauen neere Saint Clements Church. 1625.

Collation: $A^{2} B-I^{4} K^{2}, A--G^{4}, A-F^{4} G^{2}, A-H^{4} ; 36+28+26+32=122$ leaves.

Contents: A I general title; $\mathrm{A}_{2}-\mathrm{K}_{2}$ A fermon vpon the $x \times$ verfe of the v. chapter of the Booke of Iudges, $\mathrm{I} 622$ (as in no. I4); $\mathrm{A} \mathrm{I}-\mathrm{G}_{4}$ A fermon vpon the eighth verfe of the firft Chapter Of The Acts Of The Apoffles, I624 (as in no. 18); A I-G2 Encenia, I623 (as in no. 16 ); $\mathrm{AI}-\mathrm{H}_{4}$ The firft fermon preached to King Charles, 1625 (as in no. 19).

Note: This volume consists of nos. I4, 18, I6, and 19 , bound up together, a general title-page as above having been substituted for the original title-page of no. 14 .

Copy: Edmund Gosse.

SERMON PREACHED AT WHITEHALL, $1625 . \quad 4^{\circ} .1626$ Title (within double lines): A fermon, preached to the Kings Mtie. at Whitehall, 24. Febr. I625. By Iohn Donne Deane of Saint Pauls, London. [rule] And now by his Maieftes commandment Publifhed. [rule]

London, Printed for Thomas lones, dwelling at the Blacke Rauen in the Strand. I 626.

Collation: $A-G^{4} \mathrm{H}^{2} ; 30$ leaves.

Contents: $\mathrm{A}_{\mathrm{I}}$ blank; $\mathrm{A}_{2}$ title; $\mathrm{A}_{3}-\mathrm{A}_{4}$ dedication To bis sacred Maiestie; $\mathrm{B}_{\mathrm{I}}-\mathrm{H}_{\mathrm{I}}$ (pp. I-50) text (errata on $\mathrm{HI}$ b); $\mathrm{H}_{2}$ blank.

Note: On Isaiah, 1. 1. Not reprinted in the folios, or by Alford.

Copies: BM, ULC.

Pembroke College, Cambridge.

Edmund Gosse ; G. L. Keynes.

FIVE SERMONS. $4^{\circ} \cdot \quad 1626$

Title (within double lines): Fiue fermons vpon fpeciall occasions.

( $\mathrm{Viz})$

I. A Sermon preached at Pauls Croffe.

2. To the Honorable the Virginia Company

3. At the Confecration of Lincolnes Inne Chappell.

4. The firft Sermon preached to K. Charles at St. Iames, I 625.

5. A Sermon preached to his Maieftie at White-hall, 24. Febr. I625.

[rule] By Iohn Donne Deane of Saint Pauls, London. [rule] J. D. 
London, Printed for Thomas Iones, and are to bee fold at the Signe of the Blacke Rauen in the Strand. I 626.

Collation: $[\mathrm{A}]^{1} \mathrm{~B}-\mathrm{I}^{4} \mathrm{~K}^{2}, \mathrm{~A}-\mathrm{G}^{4}, \mathrm{~A}-\mathrm{F}^{4} \mathrm{G}^{2}, \mathrm{~A}-\mathrm{H}^{4}, \mathrm{~A}-\mathrm{G}^{4} \mathrm{H}^{2} ; 35+28+26+3^{2}$ $+30=15$ I leaves.

Contents: [A] general title; $\mathrm{B}_{\mathrm{I}}-\mathrm{K}_{2}$ A fermon vpon the $x x$ verfe of the v. chapter of the Booke of Iudges, $\mathrm{I} 622$ (as in no. I4 but lacking the first quire of two leaves); A r $-\mathrm{G}_{4}$ A fermon vpon the eighth verfe of the firft Chapter Of The Acts Of The Apoftles, 1624 (as in no. 18); $\mathrm{AI}-\mathrm{G}_{2}$ Enceania, $\mathrm{I} 623$ (as in no. 16); $\mathrm{Al}_{\mathrm{I}}-\mathrm{H}_{4}$ The firft fermon preached to King Charles, 1625 (as in no. 19); A $\mathrm{I}-\mathrm{H}_{2}$ A fermon, preached to the Kings Mtie. at Whiteball, 1626 (as in no. 21).

Note: This volume consists of nos. $14,18,16,19$, and 21 , bound up together. The first quire of no. 14 has been omitted and a general title-page has been substituted.

Copies: Jesus College, Cambridge.

Merton College, Oxford.

Edmund Gosse.

23 SERMON OF COMMEMORATION.

$12^{\circ} .1627$

Title (within double lines): A fermon of commemoration of the Lady Dāuers, late Wife of $\mathrm{S}^{\mathrm{r}}$. Iohn Dāuers. [rule] Preach'd at Chilfey, where the was lately buried. By Iohn Donne D. of St. Pauls, Lond. I. Iuly I627. [rule] Together with other Commemorations of Her; By her Sonne G. Herbert. [rule]

London, Printed by I. H. for Philemon Stephens, and Chriftopher Meredith, and are to be fold at their fhop at the golden Lion in Pauls Church-yard. I 627.

Collation: $\mathrm{A}-\mathrm{H}^{12} \mathrm{I}^{6} ; \mathrm{I} 02$ leaves.

Contents: A I title; A2-A6 The prayer before the Sermon; $\mathrm{A}_{7}-\mathrm{H}_{7}$ (pp. I-I70) text; H8 blank; $\mathrm{H}_{9}-\mathrm{I}_{5}$ (pp. I-17) Memorice Matris Sacrum [Latin and Greek verses by George Herbert]; I5b-I6 blank.

Note: On 2 Pet. iii. 13. Not reprinted in the folios, but it is printed by Alford, vi. 244, and by Pickering with the Devotions, 1840 (see no. 4I). The printer, I. H., is probably to be identified with John Haviland $(1621-1638)$.

Copies: BM, ULC, BLO.

St John's College, Cambridge.

Merton College, Oxford. 



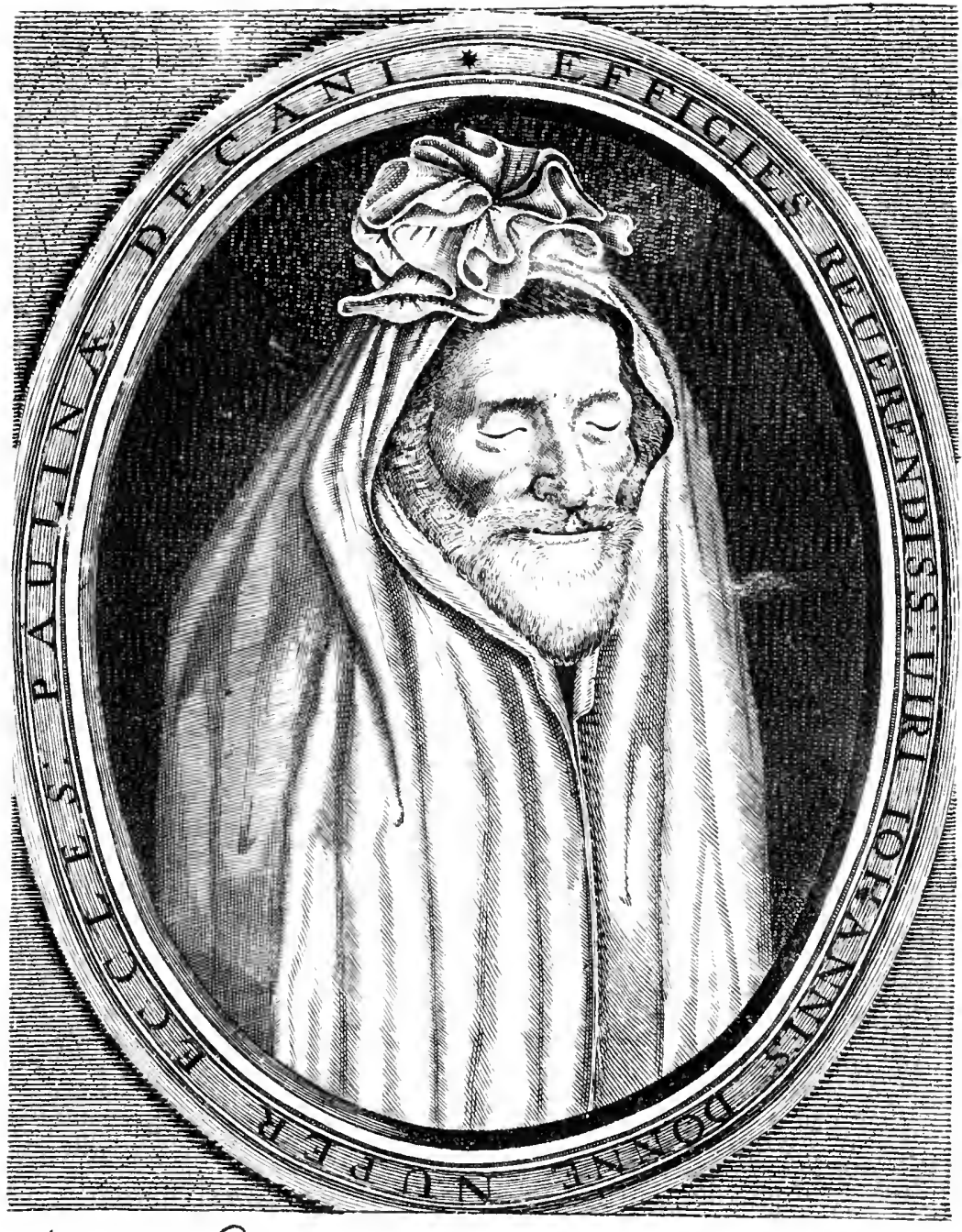

Comporis fiec Anime it Syndonsyndon Fesu. Anen.

Martin (R) Foup. And are to be fould by RR and Ben:ffifher. 
D

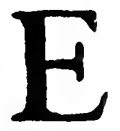

A T H

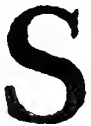

D V E L L,

$O R$,

A Confolation to the Soule, againft the dying Life, and liuing Death of the Body.

Deliuered in a Sermors at White Hall, before the

KINGS MAIESTY, in the beginning of Lent, $\quad 630$.

By that late learned and Reuerend Diuine,

IOHN DONNE, Dr. in Divinity, \& Deane of S.Pasls, London.

Being bis laft Sermon, and callcd by bic Ms aiefies boufhold The Doctors owne Fvnerael Sermon:

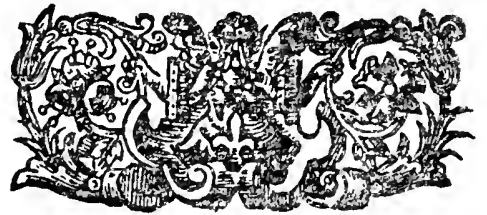

L O N DON,

Printed by T н о M S HAR PQR, for Richardidedmer and Beniamin Fiber, and are to be fold at the figne of the Talbot in Alderf-gate ficee. M. DC. $X \times X I T$.

Title-page of no. 24 . 
24 DEATH'S DUELL.

Title (within double lines): Deaths duell, or, A Confolation to the Soule, againt the dying Life, and liuing Death of the Body. Deliuered in a Sermon at White Hall, before the Kings Maiefty, in the beginning of Lent, I630. By that late learned and Reuerend Diuine, Iohn Donne, $D^{r}$. in Diuinity, $\mathcal{E}$ Deane of S. Pauls, London. Being his laft Sermon, and called by his Maiefties hourhold The Doctors owne Funerall Sermon. [ornament]

London, Printed by Thomas Harper, for Richard Redmer and Beniamin Fifher, and are to be fold at the figne of the Talbot in Alderf-gate ftreet. M.DC.XXXII.

Collation: $\mathrm{A}-\mathrm{G}^{4} ; 28$ leaves.

Contents: $A_{1}$ signature with ornament ; $A_{2}$ frontispiece; $A_{3}$ title; $A_{4}$ To the Reader signed $R . ; \mathrm{B}_{1}-\mathrm{G}_{2} a$ (pp. I-43) text; G2b blank; G3-G4a (pp. 45-47) An elegie, On Dr. Donne, Deane of Pauls, and An Epitaph on Dr. Donne; G4 $b$ blank.

Frontispicie: A head of Donne in a shroud, engraved by Martin Droeshout, after the drawing on a board made before Donne's death, which was also used for the effigy in St Paul's ${ }^{1}$. The head is in an oval $13 \times 10.5 \mathrm{~cm}$., round the edge of which is inscribed :

Effigies reuerendiss: uiri Iohannes Donne nuper eccles: Paulina decani.

Below is engraved:

Corporis hac Anima fit Syndon, Syndon Jesu

Amen.

Martin $Q$ foup. And are to be fould by $R R$ and Ben: fifher.

The plate-mark measures $16.5 \times 11 \mathrm{~cm}$.

Note: On Psalm Ixviii. 20. Reprinted as the last sermon in XXVI Sermons, 1660 (no. 3I), and by Alford, vi. 278 . It was also printed by Pickering with the Devotions, 1840 (see no. 41). The two elegies are unsigned, but were reprinted with a few changes in the text in the Poems of 1633 ( 167 and 169 ); the first is by Henry King, the second by Edward Hyde. The preface, signed $R$, is probably by the publisher, Richard Redmer.

Copies: BM (2), BLO.

Cambridge Colleges : Jesus, St John's, Trinity (2, no portraits).

Lincoln Cathedral Library.

Edmund Gosse.

1 See Walton's account, Gosse, ii. 281. 
DEATH'S DUELL.

$4^{\circ} \cdot \quad 1633$

Title (within double lines): Deaths duell,...By that late Learned and

Reverend Divine, Iohn Donne, Dr. in Divinity, and Deane of S. Pauls, London... [device]

London Printed by B. Alfop, and T. Fawcet, for Beniamin Fifher, and are to be fold at the Signe of the Talbot in Alderfgate-ftreet. M.DC.XXXIII.

Collation, Contents, Frontispiece: The same sheets as in no. 24, with cancel title.

Note: The title-page of the second edition (see next entry) seems to have been inserted in the unsold copies of the first edition.

Copy: BM.

DEATH'S DUELL.

$4^{\circ} \cdot \quad 1633$

Title (within double lines): Deaths duell...[etc. as in no. 25] M.Dc.xxxir.

Collation: $\mathrm{A}-\mathrm{F}^{4} ; 24$ leaves.

Contents: A I blank (?); A2 frontispiece; $\mathrm{A}_{3}$ title; $\mathrm{A}_{4} \mathrm{~T}_{0}$ the Reader; $\mathrm{BI}_{1}-\mathrm{E}_{4}$ (pp. I-32) text; FI-F $3 a$ (pp. 33-37) An elegie, on Doctor Donne, Deane of Pauls and An epitaph on Doctor Donne (colophon at bottom of $\mathrm{F}_{3} a$ ); $\mathrm{F}_{3} b-\mathrm{F}_{4}$ blank.

Frontispiece: As in no. 24.

Note: Pp. 24, 30, 31, are numbered 22, 31, 30. The device on the title-page of this edition is a copy of one of those used by Gryphius (1529-1550). It was first used by $T$. Creede in 1602 , and probably passed to Bernard Alsop (1602-1652) in 1617 (see no. 339 in McKerrow's Printers' and Publisbers' Devices, London, I913).

Copies: Pembroke College, Cambridge (Izaak Walton's copy, part of whose autograph is on the title-page).

G. L. Keynes.

SIX SERMONS.

$4^{\circ} \cdot 1634$

Title (within ornamental border): Six fermons upon feverall occafions, preached before the King, and elfewhere: By that late learned \& reverend Divine John Donne, Doctour in divinitie, and Dean of S. Pauls, London. [ormament between double rules]

T Printed by the Printers to the Univerfitie of Cambridge: [rule] And are to be fold by Nicholas Fuffell and Humphrey Mofley, at their fhop in Pauls Church-yard. I634. 


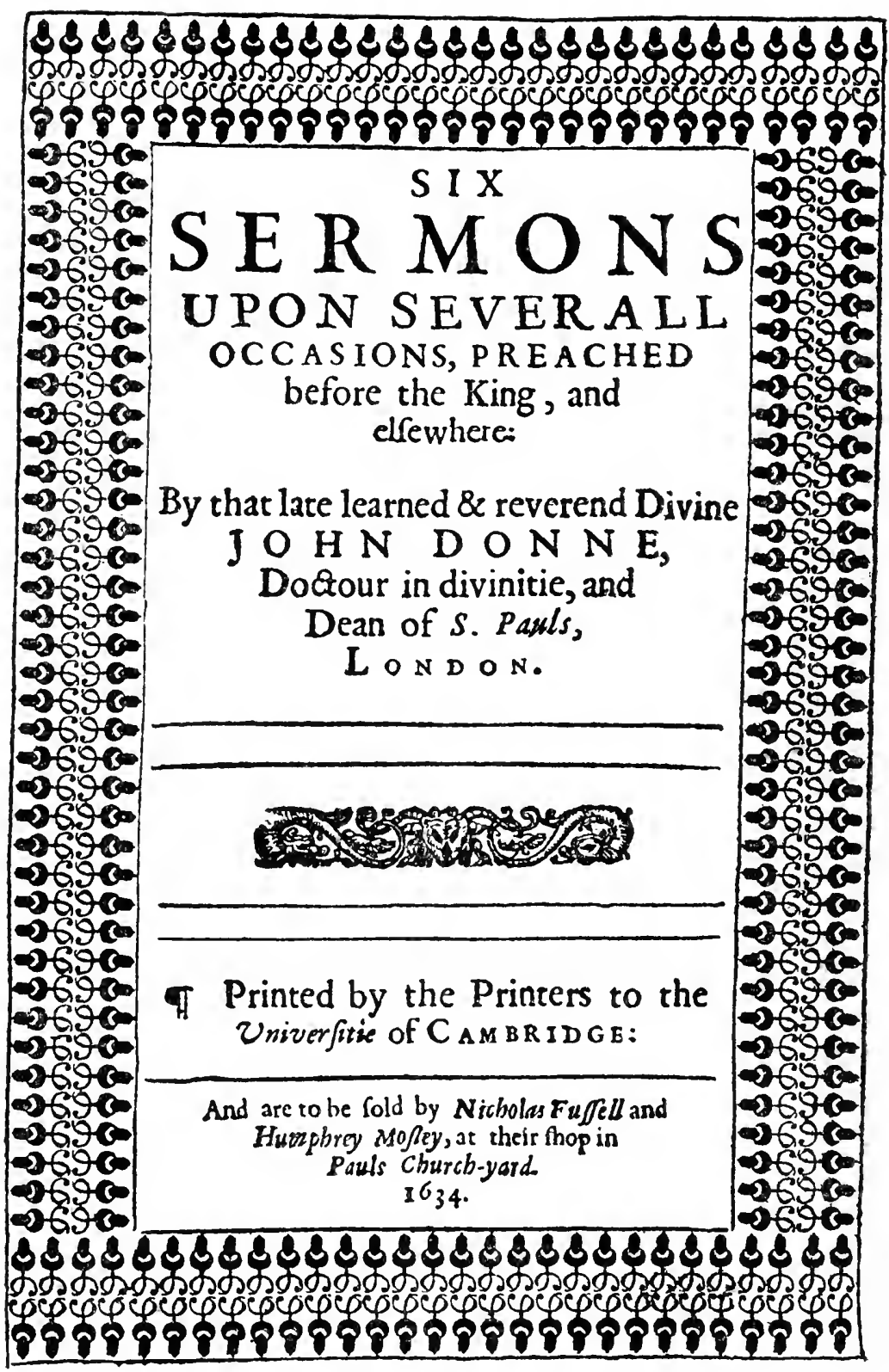

Title-page of no. 27. 


\section{Sermons}

Collation: $\mathrm{A}-\mathrm{Z}^{4} ; 92$ leaves.

Contents: Ar ornament; A2 general title;

A3 subtitle to Two fermons preached before King Charles, Upon the xxvi verfe of the firft Chapter of Genesis; $\mathrm{A}_{4}-\mathrm{F}_{2} a$ (pp. 1-37) text of first sermon; $\mathrm{F}_{2} b$ blank;

$\mathrm{F}_{3}$ subtitle to The fecond fermon preached before King Charles...; $\mathrm{F}_{4}-\mathrm{L}_{3}$ (pp. I-40) text;

$\mathrm{L}_{4}$ subtitle to A fermon Upon the xix verfe of the ii Chapter of Hosea ; $\mathrm{MI}-\mathrm{O}_{4}$ (pp. I-24) text ;

$\mathrm{PI}_{\mathrm{I}}$ subtitle to $A$ fermon Upon the xliiii verfe of the xxi Chapter of Matthew; $\mathrm{P}_{2}-\mathrm{S}_{2}$

(pp. I-26) text ;

$\mathrm{S}_{3}$ subtitle to $A$ fermon Upon the xxii verfe of the $v$ Chapter of $\mathrm{Fohn} ; \mathrm{S}_{4}-\mathrm{X}_{3} a$ (pp. I-23) text ; $\mathrm{X}_{3} b$ blank ;

$\mathrm{X}_{4}$ subtitle to $A$ fermon Upon the $x v$ verfe of the viii Chapter of fobn; $\mathrm{Y} \mathrm{I}-Z_{4}$ (pp. I-16) text.

Note: These sermons were all reprinted in the Fifty Sermons, I649 (no. 30), where they are numbered $28,29,3,35, \mathrm{I} 2$, and $\mathrm{I} 3$ respectively. They are also printed by Alford, iv. 490, 512, 30, v. 28, iv. 191, 206. The fourth is stated in the Fifty Sermons to have been preached on February 21, 16II; but this is obviously a mistake, since Donne had at that date not yet taken orders. The third sermon was also reprinted in Illustrations of the Liturgy and Ritual of the United Cburch of England and Ireland. By fames Brogden, M.A. (London, 1842, 80), vol. iii. pp. I6r -182. These sermons sometimes occur separately or two together, and they may have been so issued.

Copies: BM, ULC (2).

Cambridge Colleges: Jesus, Pembroke (Izaak Walton's copy, with autograph on A I b), Trinity (2).

Oxford Colleges: Christ Church, Merton.

Lincoln Cathedral Library.

Edmund Gosse ; G. L. Keynes (2).

SERMON ON ECCLES. xii. I.

8. 1638

Title (witbin double lines): Sapientia Clamitans, Wifdome crying out to

Sinners to returne from their evill wayes: contained in three pious and learned Treatifes, Viz.

I. Of Christs fervent love to bloudy Ierusalem.

II. Of Gods just hardning of Pharoah, when he had filled up the meafure of his iniquitie.

III. Of Mans timely Remembring of his Creator. 
Heretofore communicated to fome friends in written copies: but now publifhed for the generall good. [rule] By William Milbourne Prieft. [text from Ezech. 33. I I between rules]

London, Printed by I. Haviland, for R. Milbourne at the Unicorne neere Fleet-bridge. $\quad 1638$.

Collation: $\mathrm{A}^{2} \mathrm{~B}-\mathrm{X}^{8} ; 162$ leaves.

Contents: A I blank (?); A2 title; B1-G8a (pp. I-95) sermon I ; G8b blank; $\mathrm{H}_{\mathbf{I}}$ subtitle to sermon II; $\mathrm{H}_{2}-\mathrm{R}_{5}$ (pp. 99-250) sermon II; R6 subtitle to sermon III; $\mathrm{R}_{7}$-X 8 a (pp. 253-319) sermon III; X8b blank.

Sermon: The third sermon (pp. 25I-319) is by Donne.

Subtitle (within double lines): Mans timely remembring of bis Creator; or An expofition delivered in a Sermon upon Ecclefiaftes 12. 1.

Remember now thy Creator in the days of thy youth

[ornament between rules] London, Printed by Fobn Haviland, for Robert Milbourne. 1638 .

Note: These sermons do not seem to have been identified before. The first two are by Dr Jackson ${ }^{1}$; the third, by Donne, was reprinted as sermon 19 in XXVI Sermons, 1660 (no. 31), where it has the title: A Sermon of Valediction at my going into Germany, at Lincolnes-Inne, April 18.1619. The text of 1660 differs very considerably from that of 1638 ; probably the sermon was rewritten by Donne for publication after the first written copy had been "communicated to some friends." There is a MS. copy of this sermon in the Bodleian Library (Ashmol. 78 I, ff. I- I I). Copies: BM, ULC.

28 b Title: Wifdome crying out to Sinners to returne from their evill wayes... London, Printed by M. P. for Iohn Stafford, dwelling in Blackhorse Alley neere Fleetitreet. I639.

Collation, Contents: As in the preceding entry.

Note: A reissue by a different publisher of no. $28 \mathrm{a}$ with cancel title-page, from which the name of William Milbourne is omitted. In some copies the date on the title-page has been altered to 1640 .

Copies: ULC (1639).

Emmanuel College, Cambridge (1640).

${ }^{3}$ Thomas Jackson, Dean of Peterborough. See his Works, ed. Todd (1844), vol. xi. 36 I, and ix. $44^{8}$. 



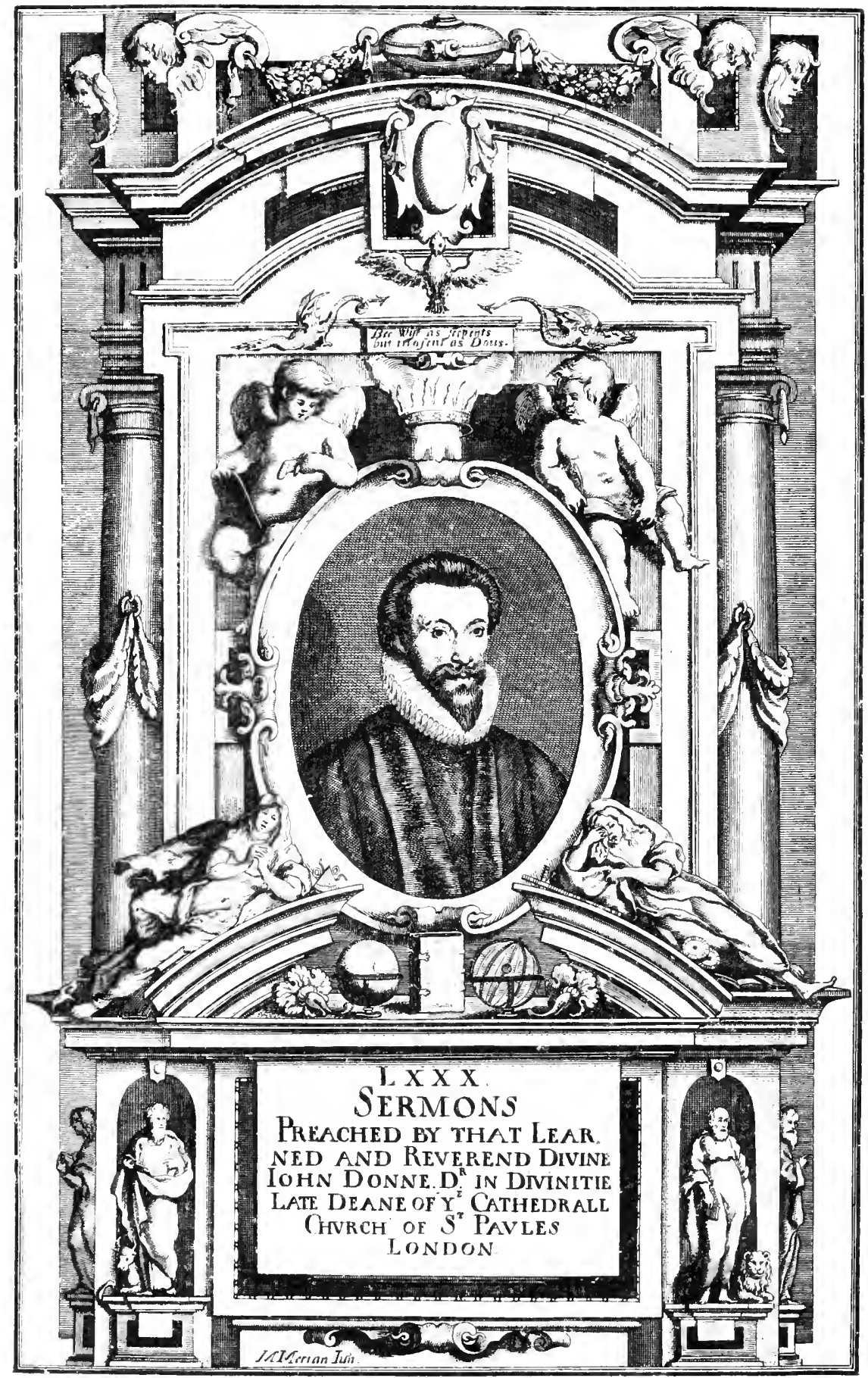


Title (within double lines): LXXX fermons preached by that learned and reverend divine, Iohn Donne, $\mathrm{D}^{\mathrm{r}}$ in divinity, Late Deane of the Cathedrall Church of S. Pauls London. [device between rules] London, Printed for Richard Royston, in Ivie-lane, and Richard Marriot in S. Dunftans Church-yard in Fleetftreet. M DC XL.

Collation: $\mathrm{A}-\mathrm{B}^{6} \mathrm{C}^{4}, \mathrm{~B}-\mathrm{Z} \mathrm{Aa}-\mathrm{Zz}$ Aaa-Zzz Aaaa ${ }^{6}, \mathrm{Bbbb}^{4} \mathrm{Cccc}^{8} ; 442$ leaves.

Contents: A I blank; A2 title; $\mathrm{A}_{3}-\mathrm{A}_{4}$ a The Epiftle Dedicatorie To his moft facred Maieftie Charles...signed by Fo: Donne [jun.]; A 6 blank; $\mathrm{A}_{5-\mathrm{Cr} a}$ The life and death of $D r$. Donne by $I z: I V a:[I z a a k I V a l t o n] ; \mathrm{C}_{1} b$ Donne's epitaph; $\mathrm{C}_{2}-\mathrm{C}_{4} a$ table of the texts of the sermons; $\mathrm{C}_{4} b$ Imprimatur, Tho: Broun. Novemb. 29. 1639; $\mathrm{B}_{1}$ subtitle to Sermons Preached upon Chrifmas-day; B2-Aaaa6 (pp. I-826) sermons and subtitles; $\mathrm{Bbbb} \mathrm{I}-\mathrm{Bbbb} 2$ table of scripture references; Bbbb3-Bbbb4 table of authors; $\mathrm{CcccI}-\mathrm{Cccc} 7$ table of principal contents (errata at bottom of Cccc7b); Cccc8 blank.

Frontispiece: Inserted between $A_{1}$ and A2. A bust of Donne in an oval, $9 \times 6.5 \mathrm{~cm}$., surrounded by an elaborate monumental design; in the upper part is inscribed: Bee Wife as ferpents | but inofent as Dous, and in the lower part: LXXX | Sermons | Preached by that Lear $=$ ned and Reverend Divine $\mid$ Iobn Donne. $D^{r}$ in Divinitie $\mid$ Laie Deane of $Y^{e}$ Cathedrall | Church of $S^{t}$ Paules |London. The engraving is signed below $M$ Merian Iun:. The plate-mark measures $31 \times 19.5 \mathrm{~cm}$. In most copies of the book is found a later state of the engraving, on which is inscribed at the sides of the oval: Etat:42, and, on the background above the head, $A$, partially erased.

Texts of the sermons :

\begin{tabular}{|c|c|c|c|c|}
\hline 1. Colos. 1. 19, 20 & 9. & Rom. 13. 7 & I 8. & Acts 2. $36^{2}$ \\
\hline Esaiah, $7 \cdot 14$ & 10. & Rom. 12.20 & 19. & Apoc. 20.6 \\
\hline Galat. $4 \cdot 4,5$ & 11 . & Mat. 9. 2. & 20. & John, 5. 28,29 \\
\hline Luke, 2. 29, 30 & 12. & Mat. 5. 2 & $2 \mathrm{I}$. & I Cor. 15. 29 \\
\hline Exod. $4 \cdot 13$ & 13. & Job, $16.17-19$ & 22. & Heb. I1. 35 \\
\hline $\begin{array}{l}\text { Lord, who hath beleeved } \\
\text { our report? (Esai. 53. I) }\end{array}$ & $\begin{array}{l}14 . \\
15 .\end{array}$ & $\begin{array}{l}\text { Amos, 5. } 18 \\
\text { I Cor. } 15.26\end{array}$ & $\begin{array}{l}23 . \\
24 .\end{array}$ & $\begin{array}{l}\text { I Cor. 13. I } 2 \\
\text { Job, } 4 \cdot 18\end{array}$ \\
\hline John, 10. IO & 16. & John, 11.35 & 25. & Mat. 28.6 \\
\hline Mat. 5. 16 & 17. & Mat. 19. 17 & 26. & I Thes. $4 \cdot 17$ \\
\hline
\end{tabular}

1 Examples of the earlier state of the plate are to be found in the B.M. Print Room, in the copy in the library of St John's College, Cambridge, and in my own copy of the book.

2 Reprinted in History and Repository of Pulpit Eloquence. By Henry' C. Fish. (New York 1857. $8^{\circ}$.) Vol. I. pp. 1 $53-165$.

J. D. 


\begin{tabular}{|c|c|c|}
\hline 27. Psal. 89.47 & 46. Acts, 9. 4 & 63. Psal. 32. 10, I I \\
\hline $28,29 . J o h n, 14.26$ & 47. Acts, 20. 25 & 64. Psal. 51.7 \\
\hline 30. John, I 4. 20 & 48. Acts, 28.6 & $65 . \quad$ Psal. 62.9 \\
\hline 31. Gen. I. 2 & 49. Acts, 23. 6,7 & 66. Psal. 63.7 \\
\hline I Cor. I 2.3 & 50. Psal. 6. I & 67. Psal. 64. 10 \\
\hline 33. Acts, 10. 44 & 51. Psal. 6. 2, 3 & 68. Psal. 65.5 \\
\hline 34. Rom. 8. 16 & $52,53 . \quad$ Psal. 6. 4,5 & 69. Psal. 66. 3 \\
\hline 35. Mat. 12. 3 I & 54. Psal. 6. 6, 7 & 70. Prov. 25. 16 \\
\hline 36,37 John, I6. 8 -I I & 55. Psal. 6. 8-10 & $7 \mathrm{I}, 72$. Mat. 4. 18-20 \\
\hline 38. II Cor. I. 3 & 56. Psal. 32. 1, 2 & 73. John, I 4. 2 \\
\hline I Pet. I. I 7 & 57 Psal. 32. 3, 4 & 74. Psal. 144.15 \\
\hline I Cor. 16.22 & 58. Psal. $32.5^{1}$ & 75. Esai. 32. 8 \\
\hline Psal. 2. 12 & 59. Psal. 32.6 & 76. Mark, 16. : $6^{2}$ \\
\hline 42. Gen. 18.25 & 6o. Psal. 32.7 & $77,78 . \quad$ I Cor. 15.29 \\
\hline Mat. 3. 17 & Psal. 32.8 & 79. Psal. 90. 14 \\
\hline 44. Rev. 4. 8 & Psal. 32.9 & 80. John, I I. 2 I \\
\hline
\end{tabular}

Note: The sermons were all reprinted by Alford, i-vi. For an account of Walton's Life of Donne as here printed see pp. 129-132. The device used on the titlepage both of this volume and of the Fifty sermons, representing Daniel praying, was first used by G. Simson in 1597. It probably passed to Miles Fletcher (16111664 ) in 1624 , and was also used by his son James (1649-1667). It is recorded as no. 308 in McKerrow's Printers' and Publishers' Devices, London, I913.

Copies: BM, ULC (2), BLO.

Cambridge Colleges: Christ's, Emmanuel, King's, Peterhouse, St John's, Trinity. Oxford Colleges: All Souls, Christ Church, Merton, New College.

Cathedral Libraries: Lincoln, Peterborough, Salisbury (Izaak Walton's copy with autograph on title-page), Worcester.

Edmund Gosse ; G. L. Keynes; J. M. Keynes.

30 FIFTY SERMONS.

Fo. $\quad$ I 649

Title (witbin double lines): Fifty fermons, preached by that learned and reverend divine, John Donne, $D^{r}$ in divinity, Late Deane of the Cathedrall Church of S. Pauls London. [rule] The Second Volume. [device between rules]

1 Reprinted in Tracts of the Anglican Fathers. (London. 1 842. $8^{\circ}$.) Vol. 1v. pp. 93-109.

2 Reprinted in Famous Sermons by English Preachers. Ed. Douglas Macleanc, M.A. (London. 1911. 8".) pp. 51-69 (with introductory note on Donne). 
London, Printed by Ja. Flether for M. F. J. Marriot, and R. Royfton. M DC XLIX.

Collation: $\mathrm{A}^{4} \mathrm{~B}-\mathrm{Z} \mathrm{Aa}-\mathrm{Qq}^{6} \mathrm{Rr}^{4} ; 236$ leaves.

Contents: A1 title; A2 dedication To the right honourable Bafil, Earle of Denby signed by Jo. Donne [jun.]; A3a For the right honourable Bolftred IVbitlock, Richard Keeble, John Leile signed by Jo. Donne [jun.]; A $36-A_{4}$ table of the texts of the sermons; $\mathrm{BI}_{\mathrm{I}}-\mathrm{Rr}_{4}$ (pp. 1-289, 300-474) sermons.

Texts of the sermons:

\begin{tabular}{|c|c|c|}
\hline I. Mat. 22. 30 & 16. Colos. I. 24 & 35. Mat. $21 .+4$ \\
\hline 2. Gen. 2. 18 & $17,18$. Mat. 18. 7 & $36-38$. Joh. 1.8 \\
\hline 3. Hosea, 2. 19 & 19. Psal. 38.2 & 39. Phil. 3. 2 \\
\hline Revel. 7. 17 & 20. Psal. 38.3 & II Cor. 5.20 \\
\hline Ephes. 5. 25-27 & 21 -23. Psal. 38.4 & Hosea, 3. + \\
\hline 6. I Joh. $5 \cdot 7,8$ & 24, 25. Ezek. 34. 19 & Prov. $14 \cdot 31$ \\
\hline Gal. 3. 27 & 26. Esai. 65.20 & Lament. $4 \cdot 20$ \\
\hline Cant. $5 \cdot 3$ & 27. Mark, 4. 24 & Mat. I I. 6 \\
\hline 10. Micah, 2. 10 & $28,29$. Gen. 1. 26 & Deut. 25.5 \\
\hline Gen. 28. 16, 17 & 30. Job, I 3.15 & 46. Psal. 34. II \\
\hline Joh. 5. 22 & 31. Job, 36.25 & Gen. 3.24 \\
\hline Joh. 8. 15 & 32. Apoc. 7.9 & Lament. 3. I \\
\hline Job, I 9. 26 & 33. Cant. 3. I I & Gen. 7.24 \\
\hline I Cor. 15.50 & 34. Luke, $23[$ not 33$] \cdot 24$ & 50. I Thes. 5. 16 \\
\hline
\end{tabular}

Note: Pp. 290-299 are omitted in the pagination. One copy in the ULC has A $3^{b}$ blank and lacks $\mathrm{A}_{4}$; this may indicate an earlier issue of the volume. The sermons were all reprinted by Alford, $\mathrm{i}-\mathrm{vi}$.

Copies: BM, ULC (2), BLO.

Cambridge Colleges: Christ's, Emmanuel, King's.

Oxford Colleges: Christ Church, Merton, New College.

Worcester Cathedral Library.

Edmund Gosse ; G. L. Keynes; J. M. Keynes.

XXVI SERMONS.

Fo. 1660

Title (within double lines): XXVI. fermons preached by that Learned and Reverend divine John Donne, Doctor in Divinity, Late Dean of the Cathedral Church of St. Pauls, London. [rule] The Third Volume. [device between rules] 
London: Printed by T. N. for James Magnes in Ruffel-ftreet near the Piazza in Covent-Garden. I $66_{\frac{0}{10}}^{\frac{0}{0}}$

Collation: $\mathrm{A}^{2} \mathrm{~B}^{2}[*]^{2}, \mathrm{~B}-\mathrm{Q} \mathrm{S}-\mathrm{Z} \mathrm{Aa}-\mathrm{Mm}^{4} \mathrm{NnOo}^{6} \mathrm{Pp}-\mathrm{Zz}$ Aaa-Ccc ${ }^{4} \mathrm{Ddd}^{6}$ Fff $\mathrm{Ggg}^{+}$; 2 I 2 leaves.

Contents : A I title; A2 dedication to King Charles II signed by Zobn Donne [jun.];

$\mathrm{B}_{\mathrm{I}}-\mathrm{B}_{2} a$ To the reader; $\mathrm{B}_{2} b$ letter from the Bishop of Peterborough to John Donne jun. on receiving the first volume of the sermons, dated 20 July 1640 ; [*]I-[*]2 table of the texts of the sermons; $\mathrm{BI}-\mathrm{Ggg} 4 a$ (pp. I-4I I) sermons; Ggg 4 b blank.

Texts of the sermons :

1. Luc. 23. 40
2. Ezck. 33. 32
3. James, 2. 12
4. I Tim. 3. 16
5. Mat. 6. 21
6. 16
7. Eccles. 8.11 Isal. 55. 19
8. Mat. 9. 13
[9. onitted]

10. Eccles. 5. 12, $13\left[\mathrm{I}_{3}, 14\right]$
(two sermons)
11. Esai. 52.
12. Gen. 32. 10
13, 14. I Tim. 1. 15
15. Acts, 7.60
16. Mat. 6. 21
17. James, 2.12
18. Prov. 8.17

I 9. Eccles, 12. 1

20. Rom. I 3. I I

21. Exod. 12. 30

22. Esther, 4. 16

23. Deut. I 2. 30

24. Prov. 22. 11

25. II Cor. 4.6

26. Psal. 68. 20

Note: This volume was very carelessly edited and printed. It actually contains only twenty-four, instead of twenty-six, sermons; sermon 9 is left out altogether, but this omission is neutralised by the fact that under sermon 10 are included two sermons on the same text; on the other hand, two of the sermons are printed twice over, nos. 16 and 17 being merely repetitions of nos. 5 and 3. The collation, printed above, will be seen to be very erratic; three of the quires, $\mathrm{Nn}, \mathrm{Oo}$, and Ddd, contain six, instead of four, leaves, and two signatures, $R$ (? with sermon 9) and Eee are omitted altogether. The pagination is very faulty, although the right number of pages, $4 \mathrm{II}$, is finally arrived at. The numbering runs as follows: $\mathrm{BI}_{\mathrm{I}}-\mathrm{Q}_{4}$ are numbered $\mathrm{I}-\mathrm{I} 20 ; \mathrm{SI}_{\mathrm{I}} \mathrm{Aa}_{4} a, \mathrm{I}_{29-1} 8_{3}$ (Aa4b is blank and has no pagination); $\mathrm{BbI}-\mathrm{Kk}_{4}, \mathrm{I}_{77-232}$; Iil-Qq4, 24I-296; Ppl-Ddd6, 285$392 ; \mathrm{FffI}-\mathrm{Ggg}_{4} a$, 397-4II. There are in addition several minor misprints in the pagination. Sermon no. 26 was first published as Death's duell, 1632 (no. 24). The sermons have all been reprinted by Alford, $\mathrm{i}-\mathrm{vi}$.

The editor has added a note to the preface on B2a which runs as follows: "By the Dates of these Sermons, the Reader may easily collect, that although they are the last that are published, they were the first that were Preached; and I did purposely select these from amongst all the rest, for, being to finish this Monument, which I was to erect to his Memory, I ought to reserve those materials that were set forth 
with the best Polish: The Impression consists onely of Five hundred, which will somewhat advance the Price; but the buyer being at liberty, he can receive no prejudice." This note explains the fact that the XXVI Sermons is considerably rarer than the two volumes of 1640 and 1649 ; it is also a smaller volume than these two, measuring about $29 \times 19 \mathrm{~cm}$. as compared with $34 \times 23 \mathrm{~cm} .^{\prime}$ It was printed by Thomas Newcomb (I649-I68I), and was twice reissued with new title-pages in 166I (see nos. 32 and 32 a). The curious device of two hands actuating pumps, with motto Dum premor, attollor, which is used on the title-pages of all the issues of this volume, is not mentioned by McKerrow in his Printers' and Publishers' Devices, London, I913; but I am informed by $\mathrm{Mr}$ Sayle that it was used for $\mathcal{F}$. Partridge in 1630, by $\mathcal{F}$. R. for G. Thomason and O. Pullen in 1645, and again by $T$. $N$. in 1670.

Copies: ULC, BLO.

Christ's College, Cambridge.

Worcester Cathedral Library.

Edmund Gosse.

XXVI SERMONS.

Fo. 166 I

Title (within double lines): XXVI. fermons (Never before Publifh'd) preached by that Learned and Reverend. Divine John Donne, Doctor in Divinity, Late Dean of the Cathedral Church of St Pauls, London. [rule] The Third Volume. [device between rules]

London. Printed by Thomas Newcomb, and are to be fold at the feveral Book-Sellers-hops in London, and at Weftminfter-Hall. I66I. Collation, Contents, Texts of the sermons: As in no. $3 \mathrm{I}$.

Note: Both this book and no. 32 a consist of the same sheets as no. $3^{1}$ with cancel title-pages.

Copy: BM.

XXVI SERMONS.

Fo. $166 \mathrm{r}$

Title (within double lines): XXVI. fermons preached by that Learned and Reverend Divine John Donne,...[etc., as in no. 32]

London, Printed at the Charge of Dr. Donne, and are to be fold at his

1 In a recent catalogue Messrs Pickering and Chatto offered a "large paper copy" uniform in size with the other two volumes; I have seen no other copy in this condition. 
Houfe in Covent-Garden, neare the Fleece-Tavern; at the feveral Bookfellers-rhops in London and at Weftminfter-hall, I66I.

Collation, Contents, $\mathcal{T}_{\text {exts }}$ of the sermons : As in no. $3 \mathrm{I}$.

Copy: G. L. Keynes.

33 SERMONS, ETC.

6 vols. 8o. 1839

Title: The Works of John Donne, D.D., Dean of Saint Pauls I62 II631. With a memoir of his life. By Henry Alford, M.A., Vicar of Wymeswold, Leicestershire, and late Fellow of Trinity College, Cambridge. In six volumes. Vol. I. [etc.]

London: John W. Parker, West Strand. M.Dccc.xxxix.

Collation: Vol. I. pp. xxxii +587 . Vol. II. pp. iv +588 . Vol. III. pp. iv +6I4.

Vol. Iv. pp. iv +590 . Vol. v. pp. iv +623 . Vol. vi. pp. iv +569 .

Contents : Vol. I. pp. ix-xxviii Life of Dr Donne.

Vol. 1. p. I-Vol. vi. p. 298 Sermons 1-cLvilı.

Vol. vi. pp. 299-44I Letters to several persons of honour.

Vol. vi. pp. 443-569 Poems.

Frontispiece: Portrait of Donne, $11.5 \times 9 \mathrm{~cm}$., engraved by W. Holl "from the original painting by Vandyke in the possession of F. Holbrooke, Esq. "

Note: This is the only attempt that has ever been made to reprint all the sermons. The letters and the selection of poems are very imperfectly edited, and these texts are not of any importance. 
DEVOTIONS 
. 


\section{DEVOTIONS}

\section{Bibliographical Preface}

Donne composed the volume of meditations, expostulations, and prayers, known as his Devotions, during a serious illness, which confined him to his bed during the last months of the year 1623. At one period he was reduced to a very low state and was not expected to recover. Nevertheless his brain was active, and he sought to pass the time away by recording his states of mind and introspective thoughts; the result is a most remarkable and interesting book. It was printed soon after his recovery early in 1624 , and a letter ${ }^{1}$ to Sir Robert Ker written during February or March, I624, has been preserved, which appears to have accompanied the proofs? of the Devotions and asks for advice concerning the projected dedication to the Prince of Wales. Several other letters have survived, which were sent with gift-copies of the book; these were addressed to the Queen of Bohemia (Tobie Matthew collection, no. 5), to a lady of the court of Bohemia (Gosse, no. 22), to the Duke of Buckingham (Tobie Matthew collection, no. 9), and, probably, to the Earl of Dorset (ibid. no. го). The book seems to have been a popular one, and it passed through three editions (five issues) during Donne's lifetime; two more editions with frontispieces engraved by Marshall were published during the seven years succeeding his death. The Devotions were reprinted by Pickering in I 840 and by Talboys in $\mathrm{r} 84 \mathrm{I}$, but the work has not been issued since then and is very little known at the present time. I do not know of any translation or foreign edition of the Devotions, but the following statement is made by Morhof in his Polyhistor in the course of his short account of Donne's works: "Scripsit et Meditationes super morbo suo sacras, quæ in Linguam Belgicam conversæ et Amstelodami I 655 in $\mathrm{I}^{\circ}{ }^{\circ}$ editæ sunt ${ }^{2} . "$ This statement is sufficiently definite to make it probable that such a translation does exist ; if so, it is probably by Sir Constantine Huyghens, who had already translated some of Donne's poems (see no. 85).

${ }^{1}$ Letters, 1651 , no. 90.

2 Polyhistor, 171 t, lib. vı. cap. w. \$ 18. See no. 109.

J. D. 
34 DEVOTIONS.

I $2^{\circ} . \quad 1624$

Title (within double lines): Deuotions vpon Emergent Occafions, and feuerall Ateps in my Sicknes: Digefted into

I. Meditations vpon our Humane Condition.

2. Expoftulations, and Debatements with God.

3. Prayers, vpon the feuerall Occafions, to him.

[rule] By Iohn Donne, Deane of S. Pauls, London. [rule]

London, Printed by A. M. for Thomas Iones. I 624 .

Collation: $\mathrm{A}^{6} \mathrm{~B}-\mathrm{Z} \mathrm{Aa}-\mathrm{Dd}^{12} \mathrm{Ee}^{4} ; 322$ leaves.

Contents : A 1 title; $\mathrm{A}_{2}-\mathrm{A}_{4}$ (both $\mathrm{A}_{2}$ and $\mathrm{A}_{3}$ with sign. $\left.\mathrm{A}_{3}\right)$ The Epifle Dedicatorie To the moft excellent Prince, Prince Cbarles; A5-A6a Stationes, frue Periodi in Morbo, ad quas referuntur Meditationes fequentes; $\mathrm{A} 6 b$ errata; $\mathrm{BI}-\mathrm{Ee}_{3}$ (pp. I630) text; Ee4 blank.

Note: This edition of the Devotions and all the subsequent editions up to 1638 were printed by Augustin Matthewes (1619-1653).

Copies: BM, ULC.

Trinity College, Cambridge (2).

All Souls College, Oxford.

35 DEVOTIONS.

12. 1624

Title (within double lines): Deuotions vpon Emergent Occafions,...[etc. as in no. 34]

London, Printed for Thomas Iones. I 624.

Collation, Contents : As in no. 34.

Note: Apparently another issue of no. 34, with a different imprint.

Copy: Library of Beverley Chew, Esq., New York (examined for me by Miss Henrietta C. Bartlett).

36 DEVOTIONS.

120. 1624

Title (within double lines): Deuotions vpon Emergent Occafions,...By Iohn Donne, Deane of S. Pauls, London. [rule] The fecond Edition. [rule]

London, Printed by A. M. for Thomas Iones. I 624 . 


\section{DEVOTIONS V PON \\ Emergent Occafions, and fe-}

uerallfteps in my Sicknes:

\section{Digefted into}

I. MEDITATIONS upOnour $H u$ mane Condition.

2. EXPOSTVLATIONS, and Debatements with God.

3. PRAYERS, vponshe feuerall Occafions, to bim.

By IOHN DONN E, Deane of S.Pauls, London.

LONDON,

Printed by $\mathcal{A}$. M. for Thomas IONES. I 624 .

Title-page of no. 34 . 
Colophon: London Printed for Thomas Iones, and are to be fold at the black Rauen, in the Strand. 1624.

Collation: $\mathrm{A}-\mathrm{Z} \mathrm{Aa}-\mathrm{Bb}^{12} ; 300$ leaves.

Contents: Ar blank; A2 title; $\mathrm{A}_{3}-\mathrm{A}_{4}$ T be Epifle Dedicatorie; $\mathrm{A}_{5}$ Stationes etc.; A6-Bbi2a (pp. I-589) text; Bbr2b colophon.

Copies: ULC, BLO.

Christ Church, Oxford.

G. L. Keynes.

\section{DEVOTIONS.}

$12^{\circ} . \quad 1626$

Title (within double lines): Deuotions vpon Emergent Occafions,...By Iohn Donne, Deane of S. Pauls, London. [rule] The third Edition. [rule]

London, Printed for Thomas Iones, and are to be fold at the Signe of the Black Rauen in the Strand. 1626.

Colopbon: London Printed for Thomas Iones, and are to be fold at the black Rauen, in the Strand. I627.

Collation: $\mathrm{A}-\mathrm{Z} \mathrm{Aa}-\mathrm{Bb}^{12}$; 300 leaves.

Contents: A I blank; A2 title; $\mathrm{A}_{3}-\mathrm{A}_{4}$ The Epiftle Dedicatory; A 5 Stationes etc.; A6-Bbi2a (pp. I-589) text; Bbr2b colophon.

Note: The two dates on the title-page and colophon suggest that the composition of this edition was begun in 1626 and finished in 1627 . Later the date on the titlepage was altered to 1627 (see no. 38 ).

Copies: BM.

Lincoln Cathedral Library.

38 DEVOTIONS.

$12^{\circ} . \quad 1627$

Title (witbin double lines): Deuotions vpon Emergent Occafions,...[etc. as in no. 37]

London,... 1627 .

Colophon, Collation, Contents: As in no. 37 .

Note: The same sheets as in no. 37 , with the date altered on the title-page, presumably while the book was in the press, since the title-page is not a cancel.

Copies : Corpus Christi College, Oxford.

Edmund Gosse (in contemporary binding with initials I. D. stamped in gold on the front cover; possibly Donne's own copy); G. L. Keynes. 



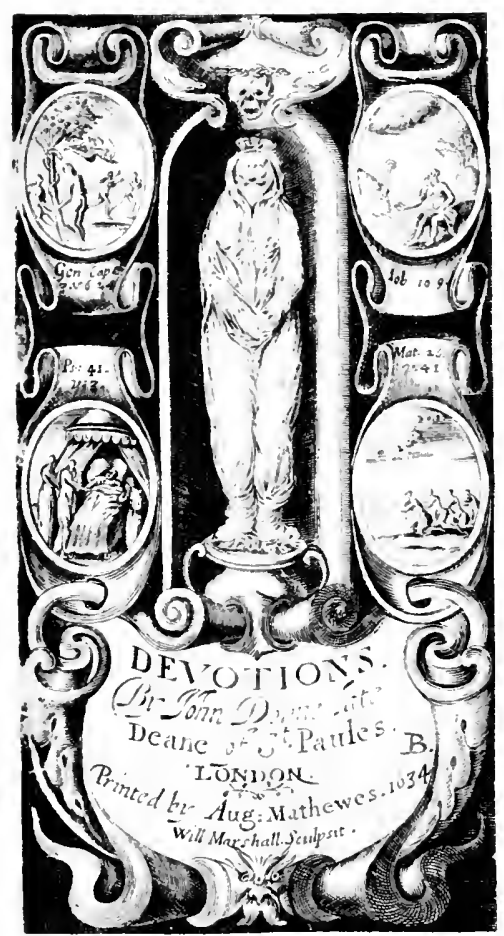


DEVOTIONS.

I $2^{\circ} . \quad 1634$

Title: Devotions vpon Emergent occafions, and feverall tteps in my Sickneffe. Digefted into

I. Meditations, upon our humane Condition.

2. Expoftulations, and Debatements with God.

3. Prayers, upon the feverall Occafions, to him.

[rule] By Iohn Donne, Deane of S. Pauls, London. [rule] The fourth Edition. [rule]

London, Printed by A. M. and are to be fold by Charles Greene, I 634 . Colophon: London, Printed by A. M. and are to bee fold by Charles Greene. $\quad$ I 634 .

Collation: $\mathrm{A}-\mathrm{Y}^{\mathrm{12}} ; 26_{4}$ leaves.

Contents: A I title; $A_{2}-A_{3}$ dedication; $A_{4}$ Stationes etc.; $A_{5}-Y_{10}$ text; Yrob colophon; YII-Y 12 blank.

Frontispiece: Inserted before Ar. The effigy of Donne in a niche wrapped in his winding sheet; above his head is a skull wreathed with laurel. On either side are two biblical scenes with their texts inscribed below and above as follows: Gen: Cap: 3. v. 6. 24, Ps: 41. v: 3, Iob: 10. 9., Mat: 26. v: 4 I.

Below is a shield inscribed: Devotions. | By John Donne late $\mid$ Deane of $S^{t}$. Paules. London. | Printed by Aug: Matbewes. 1634 | Will: Marshall Sculpsit.

The engraving measures $9.5 \times 5 \mathrm{~cm}$.

Copies : Cambridge Colleges: Pembroke, Trinity.

DEVOTIONS.

I $2^{\circ} .1638$

Title: Devotions upon Emergent occafions, and feverall fteps in my Sickneffe... [rule] By Jo: Donne, late Deane of St. Pauls, London. [rule] The fifth Edition. [rule]

London, Printed by A. M. and are to be fold by Richard Royston in Ivie lane. I638.

Collation: $\mathrm{A}-\mathrm{T}^{12} ; 228$ leaves.

Contents: A1 title; A2 dedication; A3 Stationes etc.; A4-Tro text; Tr I I Imprimatur. Guil. Bray. Novemb. 23. 1637.; Tा Ib-T12 blank.

Frontispiece: As in the edition of 1634 .

Copies: BM (no frontispiece).

St John's College, Cambridge (no frontispiece). 


\section{$46 \quad$ Bibliography of Fohn Donne}

41 DEVOTIONS.

8. 1840

Devotions by John Donne D.D. Dean of St Pauls with two sermons

I On the decease of Lady Danvers mother of George Herbert

II Deaths duel-his own funeral sermon

to which is prefixed his life by Izaak Walton.

London: William Pickering $\mathrm{M}$ Dccc xu.

8. pp. cviii +227 .

Frontispiece : Engraved reproduction (enlarged to $1 \mathrm{I} \cdot 7 \times 6.2 \mathrm{~cm}$.) of Marshall's frontispiece to the fourth edition of the Devotions, 1634 (no. 39).

Note: For the original editions of the two sermons, see nos. 23 and 24.

42 DEVOTIONS.

I $2^{\circ} . \quad 1841$

Donne's Devotions.

Oxford: D. A. Talboys. I $8+1$.

$12^{\circ}$. pp. xiv +292 . 


\section{JUVENILIA}





\section{JUVENILIA}

\section{Bibliographical Preface}

Donne's Juvenilia are clever and entertaining trifles, which were probably written before 1600 during the more wanton period of their author's life. Owing to their scurrilous nature they could not be published during Donne's lifetime, but in 1632 , shortly after his death, part of them were licensed by Sir Henry Herbert. The licences were granted on October 25, 1632, but on November I4 an order of inquiry was delivered at the King's command by the Bishop of London calling upon Sir Henry Herbert to explain before the Board of the Star Chamber his reasons "why hee warranted the booke of D. Duns paradoxes to bee printed"." The inquiry, however, was ineffectual in preventing the publication of the book, the title-page of which is dated i633. It is not known through what channels the publisher, Henry Seyle, obtained possession of the text, but it is probable that the publication was quite unauthorised, and took place even without the knowledge of John Donne, jun., who, in his edition of 1652 , makes no reference to any previous issues. Although the King did not succeed in stopping the publication of the Juvenilia, the licences were withdrawn, so that when the demand for the book encouraged the publication of a second edition during the same year, the publisher took upon himself to issue it unlicensed; not content with this he even added to the first problem, "Why have bastards best fortunes?," which was particularly

1 This interesting document was discovered by Mr Gosse among the State Papers (Gosse, i. 16) and is printed in the Grolier Club Catalogue, 1905.

J. D. 
insulting to the Court, twenty-three lines which had not appeared in the first edition. It is possible that steps were taken to suppress this edition, which is now considerably rarer than its predecessor.

In 1652 the younger Donne, in the course of his exploitation of his father's writings, issued an authorised edition of the Juvenilia, in which he increased the number of the paradoxes from eleven to twelve and that of the problems from ten to seventeen, even the offensive passages in the first problem being now allowed to remain. To these he added two "Characters," "An Essay of Valour," "A Sheaf of Miscellany Epigrams," a reprint of Ignatius bis Conclave, and, finally, the Essays in Divinity. The Epigrams purport to have been written by Donne in Latin and to have been translated into English by Jasper Mayne, D.D.' They may have been printed by the younger Donne in good faith, as it seems to be certain that Donne's epigrammata mea Latina once existed²; but the epigrams attributed to him in this volume are certainly spurious and may well have been composed as well as translated by Jasper Mayne, who was an unprincipled though witty divine (see Gosse, i. 16). The Essays in Divinity had been printed in $165 \mathrm{I}$ for a different publisher, but, as is explained elsewhere (see p. 69), they rarely, if ever, occur as a separate volume; for the younger Donne sought to temper the secularity, and even obscenity, of the Juvenilia by issuing them in company with the Essays in Divinity and in this way to invest the volume with an altogether fictitious respectability. This fact has not previously been noticed, although it is laboured by the editor in his preface: "I humbly here prefent unto your Honor, Things of the leaft and greateft weight, that ever fell from my Father's Pen; which yet, are not fo light that they feem vain; nor of fuch weight, that they may appear dull or heavy unto the Reader. The Primrofes and Violets of the Spring entertain us with more Delight, than the Fruits of the Autumn; and through our Gardens we pafs into our Groves and Orchards; preferving, and candying the Buds and Bloffomes of fome

1 The epigrams were originally advertised by the publisher Moseley in a catalogue of his books as Fasciculus Poematum et Epigrammatum Miscelaneorum Authore Johanne Dome [sic] D.D. Englished by Jasper Maine, Doctor in Divinity. This may account for the fact that Lowndes incorrectly records a separate issue of the Epigrams, dated ${ }_{1} 6_{32}$.

2 Gosse, i. 17. 
Trees, admitting them amongft our Delicacies $\mathcal{E}$ Sweet-meats; when as, the riper Fruit ferves onely to quicken and provoke our Appetite to a coarfer Fare... They are the Effays of two Ages, where you may fee the quicknefs of the firft and the firmnefs of the latter.... Here then you have the entertainment of the Authors Youth; and the Affumption of his Wit when it was employed in more Heavenly things." Beyond the facts that the volumes usually occur bound up together and that the original dedication of the Essays in Divinity has been cancelled, there is nothing in the bibliographical constitution of the whole to shew that they actually form one volume; but the passages quoted above make quite evident the editor's intention.

Even in 1652 the Paradoxes and Problemes were not printed entire, for another problem, entitled "Why was Sir Walter Raleigh thought the fittest man to write the history of these times?," has been preserved at Oxford (Tanner MSS. 299, f. 32), the copier stating that it "was so bitter that his son, Jack Donne LL.D., thought fit not to print it with the rest"; it is printed by Gosse, ii. 52 .

The Juvenilia have not been reprinted since ${ }^{6} 5_{52}$. 
Title: [double rule] Iuuenilia: or certaine paradoxes, and problemes, written by I. Donne. [rule and ornament]

London, Printed by E. P. for Henry Seyle, and are to be fold at the figne of the Tygers head, in Saint Pauls Church-yard, Anno Dom. I633.

Collation: $\mathrm{A}-\mathrm{H}^{4} ; 3^{2}$ leaves.

Contents: AI blank; A2 $a$ title; A2 $b$ list of Paradoxes; A3-Fı $a$ Paradoxes I-XI;

$\mathrm{F}_{\mathrm{I}} b$ Imprimatur, granted by Henry Herbert, 25 October 1632; F2a subtitle to Problems; $\mathrm{F}_{2} b$ list of Problems; $\mathrm{F}_{3}-\mathrm{H}_{4} a$ Problems $\mathrm{I}-\mathrm{X} ; \mathrm{H}_{4} b$ Imprimatur. Paradoxes:

I. A Defence of Womens Inconftancy.

II. That Women ought to Paint.

III. That by Difcord things increafe.

IV. That Good is more common than Euill.

V. That all things kill themfelues.

VI. That it is poffible to find fome vertue in fome Women.

VII. That Old men are more fantaftike than Young.

VIII. That Nature is our worft guide.

IX. That only Cowards dare dye.

$X$. That a Wife man is known by much laughing.

XI. That the gifts of the Body are better than thofe of the Minde.

Problems :

I. Why haue Baftards beft Fortunes?

II. Why Puritans make long Sermons?

III. Why did the Diuell referue Iefuites till thefe latter Dayes?

IV. Why is there more Variety of Greene, than of any other Colour?

V. Why doe Young Lay-men fo much ftudy Diuinity?

VI. Why hath the Common Opinion afforded Women Soules?

VII. Why are the Faireft falfeft?

VIII. Why Venus Starre only doth caft a hadow ?

IX. Why is Venus Starre Multinominous, called both Hefperus and Vefper?

$X$. Why are new officers leaft oppreffing?

Note: The Imprimaturs are as follows:

Thefe eleuen [ten] Paradoxes [Problemes], may bee printed: this fue and twentieth of October, Anno Domini, one thoufand fix bundred thirty and two Henry Herbert

In my own copy of the book the first Imprimatur has been omitted, Fi $b$ being blank; this is unusual and difficult to explain. 


\section{IVVENILIA \\ OR}

CERTAINE

PARADOXES,

$A N D$

PROBLEMES,

WRITTEN BY

I. DON NE.

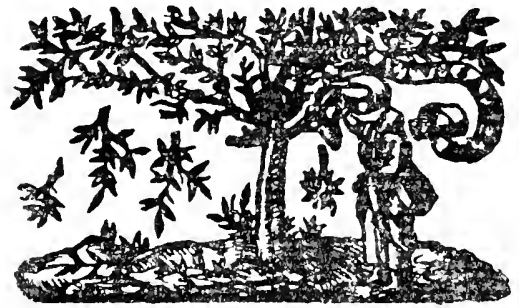

LONDON,

Printed by E.P. for Henry seyle, and are io be fold at the ligne of the Tygers head, in Saint Pauls Churchyard, Anno Dom, 1633.

Title-page of no. 43. 
Both this and the second edition were printed by Elizabeth Purslowe (16331646). The device used on the title-pages of both editions is a copy of one of those used by the family Estienne of Paris. It was first used by G. Purslowe (1614-1632) in 1618 and passed to Elizabeth Purslowe in 1632-3. It is recorded as no. 311 in McKerrow's Printers' and Publishers' Devices, London, 1913 .

Copies: BM (2), ULC, BLO (2).

Cambridge Colleges: Emmanuel, Trinity.

All Souls College, Oxford.

Lincoln Cathedral Library.

John Rylands Library, Manchester.

G. L. Keynes.

44 JUVENILIA.

$4^{\circ} \cdot \quad 1633$

Title: Iuuenilia or certaine paradoxes and problemes, written by I. Donne. [rule] The fecond Edition, corrected. [ornament between rules]

London, Printed by E. P. for Henry Seyle, and are to be fold at the figne of the Tygers head, in St. Pauls Church-yard, Anno Dom. I633.

Collation: $\mathrm{A}-\mathrm{F}^{4} ; 24$ leaves.

Contents: A I blank; A $2 a$ title; A2 $b$ list of Paradoxes; $\mathrm{A}_{3}-\mathrm{D}_{4} a$ (pp. I-27) Paradoxes I-XI; $\mathrm{D}_{4} b$ (p. 28) blank; Eı $a$ (p. 29) subtitle to Problemes; Eı $b$ (p. 30) list of Problemes; E2-F4 (pp. 3I-44) Problemes I-X.

Paradoxes and Problems: As in the previous edition, with the addition of twentythree lines to Problem I.

Note: Sir Henry Herbert's Imprimaturs are omitted from this edition, which was probably unlicensed (see bibliographical preface).

Copies : Cambridge Colleges: Jesus, St John's (imperfect).

Corpus Christi College, Oxford.

Edmund Gosse; G. L. Keynes.

45 PARADOXES, PROBLEMS, ESSAYS.

12. $165^{2}$

Title (within ornamental border): Paradoxes, problems, effayes, characters, Written By Dr Donne Dean of Pauls. To which is added a Book of epigrams, Written in Latin by the fame Author; tranflated into Englifh by J. Maine, D.D. As alfo, Ignatius his Conclave, a satyr, Trannated 


\section{Fuvenilia}

out of the Originall Copy written in Latin by the fame Author; found lately amongtt his own Papers.

De Iefuitarum difsidiis:

Quos pugnare, Scholis, clamant, hi (difcitc Regna)

Non funt Vnanimes, conveniuntq; nimis.

[rule] London, Printed by T. N. for Humphrey Mofeley at the Prince's Armes in St Paul's Church-yard, I652.

Collation: $\mathrm{A}^{8} \mathrm{~B}-\mathrm{K}^{12} \mathrm{~L}^{4} ; \mathrm{A}^{4} \mathrm{~B}-\mathrm{K}^{12} \mathrm{~L}^{4} ; \mathrm{1} 20+\mathrm{I} 16$ leaves.

Contents: Ar title; A2-A 5 dedication To the Right Honourable Francis Lord Newport, Baron of Higharcale, signed Jo. Donne, From my boufe in Cov. Gard. March 2. 1652; A6-A8a The table; A8b Ben. Jobnfon to the Author (12 lines); $\mathrm{B}_{\mathrm{I}}-\mathrm{L} 2 a$ (pp. 1-219) text; L2b-L 4 blank; Ar-L4 Essays in Divinity (as in no. 50).

Paradoxes: I.-XI. as in the editions of 1633 .

XII. That Virginity is a Vertue [placed after An EJfay of Valour, E5-E8].

Problems :

I. - X. as in the second edition of 1633 .

XI. Why doth the Pox fo much affect to undermine the Nofe?

XII. Why die none for Love now ?

XIII. Why doe women delight much in Feathers?

XIV. Why doth not Gold foyle the Fingers?

XV. Why doe Great men of all dependants, choofe to preferve their little Pimps?

XVI. Why are Courtiers fooner Atheifts, then men of other conditions?

XVII. Why are Statefmen moft incredulous?

Characters: The Character of a Scot at the firft fight.

The True Character of a Dunce.

Essay: An Eflay of Valour.

Epigrams : A Sheaf of Miscellany Epigrams:

I. Upon one who for his wives fault took it ill to be called Cuckold.

2. Upon One Roger a Rich Niggard, familiarly unacuainted with the Author.

3-4. Upon a Whore barren and not barren.

5-7. On an old Bawd.

8. On a Bawdy-houfe. 
9-10. Upon an old rich fcolding Woman who being married to a poor young man upbraided him daily with the fmallnefs of his Fortune. The Hurbands complaint.

II-I3. On her unpleafing kiffes.

14-15. On the fame old Wife.

16-19. Upon one who faw the Picture of his fcolding wife in a Painters thop.

20-22. Upon a Pipe of Tobacco miftaken by the Author for the Tooth-ach.

23-26. To the Tobacco-feller.

27-31. Upon a Town built in the place where a wood grew; From whence 'tis called the Dukes-Wood, or the Burfe.

32-36. Upon a navigable River cut through a Town built out of a Wood.

37-4I. Upon the Medows over-flown there.

42-46. Upon a piece of ground ore-flown, where once a Leaguer quartered.

47-51. A Dutch Captain of Foot, having with his Soldiers entred a Breach, and there a while fought valiantly with a Two-handed Sword; In the very point of $V$ ictory, being mortally wounded, fpake thus:

52. His Will.

53-55. To the Prince of Aurange, on his famous Victory over the Spaniards in Dukes-Wood.

56. A Panegyrick on the Hollanders being Lords of the Sea. Occafioned by the Authors being in their Army at Dukes-Wood.

57. To Sleep, ftealing upon him as he ftood upon the Guard in the corner of a running Trench, at the fiege of Duke's-Wood.

58. To his Fellow Sentinels.

59. In Comædam celeberrimam Cintbiam dictam ad inftantiam alterius fecit. Idem Anglicè verfum.

On one particular paffage of her action, when the was to be ftript of her cloaths by Fulvio, but not without much refiftance. Videns excogitavit.

Ignatius bis Conclave: As in the editions of I6I I et sequ. (subtitle dated 1653) but without the leaves $T$ he printer to the Reader.

Essays in Divinity: See no. 50 (title-page dated 1651).

Note: Printed, with the exception of the Essays in Divinity, by Thomas Newcomb (1649-1681). The lines by Ben Jonson on A8b are from his Epigrams, 1616; they were also printed in Donne's Poems of 1650 (no. 82).

Copies: BM.

Trinity College, Cambridge.

G. L. Keynes. 
PARADOXES, PROBLEMS, ESSAYS.

$12^{\circ} \cdot 1652$

Title (within ornamental border): Paradoxes, problemes, effayes, characters, Written By Dr Donne Dean of Pauls :... [rule]

London, Printed by $\mathrm{T}: \mathrm{N}$ : for Humphrey Mofeley at the Prince's Armes in St Pauls Churchyard, I652.

Collation: As in no. 45 .

Contents: A I title; A2-A6a dedication; A6b-A8a The table; A86 Ben. Fobnfon to the Autbor; $\mathrm{BI}_{1}-\mathrm{L}_{4}$ as in no. 45.

Paradoxes, etc.: As in no. 45 .

Note: In this issue the first quire of eight leaves has been reset, but the other sheets have been left untouched. There are certain minor alterations in the title-page, and the dedication, which is printed in a different type, contains an additional adulatory passage on $\mathrm{A}_{3} b$.

Copies: BM, BLO.

Christ Church, Oxford.

Edmund Gosse. 
BIATHANATOS 


\section{BIATHANATOS}

\section{Bibliographical Preface}

Biathanatos is the earliest of Donne's controversial writings. His neurotic temperament had for many years been fascinated by the thought of suicide and in this work, written probably in I608, he sought by the most ingenious casuistry to justify the act of self-destruction. "Whensoever any affliction assailes me," he wrote in the preface, "mee thinks I have the keyes of my prison in mine owne hand, and no remedy presents it selfe so soone to my heart, as mine own sword. Often Meditation of this hath wonne me to a charitable interpretation of their action, who dy so: and provoked me a little to watch and exagitate their reasons, which pronounce so peremptory judgements upon them.... And though I know, that the malitious prejudged man, and the lazy affectors of ignorance, will use the same calumnies and obtrectations towards me, (for the voyce and sound of the Snake and Goose is all one) yet because I thought, that as in the poole of Bethsaida, there was no health till the water was troubled, so the best way to finde the truth in this matter, was to debate and vexe it, I abstained not for feare of mis-interpretation from this undertaking. Our stomachs are not now so tender, and queasie, after so long feeding upon solid Divinity, nor we so umbragious and startling, having been so long enlightened in Gods path, that wee should thinke any truth strange to us, or relapse into that childish age, in which a Councell in France forbad Aristotles Metapbysiques, and punished with Excommunication the excribing, reading, or having that booke." Donne was unwilling either to publish or to destroy this curious and characteristic product of his brain, and it was therefore handed round to his friends in manuscript; one such 
copy, which was given to Lord Herbert of Cherbury in 1619 , is now in the Bodleian Library, another was sent to Sir Robert Ker in the same year, and the letters which accompanied these two copies have survived (Letters, I65I, nos. 7 and 8). His desire was that after his death the book should still be preserved but not published; his son nevertheless assumed the responsibility of making it public, and it was duly licensed on September 20, 164+. The title-page of the first issue is not dated and appears to be unfinished, but this was probably an oversight on the part of the printer. This issue is somewhat rare, the majority of copies containing the titlepage which was substituted for the original one in 1648 . Several giftcopies of the Biathanatos are known to me; one of these, in the possession of Mr S. G. Dunne, was presented to "Ye Rt. Honourable the Kinsmoll" i.e. Lady Kingsmell; two others, now in the Cambridge University Library, contain letters in the younger Donne's autograph, which are but little known ${ }^{1}$, and are of sufficient interest to warrant their being printed here:

I. $\mathrm{S}^{\mathrm{r}}$

For his much honored frinde Mr Lee at the Cockpitt

I take the bouldnesse to present to your hands this booke, hopinge that it may bee welcome to you, euen for the Patrones sake, who has receaued it soe nobly, that, I cannot doubt, but that all his frinds, will entertaine it as somethinge that belongs to my Lorde Herbert, and, has lyen still these fiftie last years, to expect a Patrone noble enough to entertaine a Peece that is an absolute Originall, and, I thinke, drawen by noe very ill a hande.

Couent Garden

$S^{r}$ your most humble Seruant Jo: Donne

October 26

2.

For $y^{e} R^{t} r^{d}$ Edward Carter Esq.

$\mathrm{S}^{\mathrm{r}}$

I haue, here, sent you a Booke, that may, peraduenture, giue you some entertainement out of the noueltie of the subiect, but that is not all 1807 . 
my reason of presentinge it to you, at this time; For, since I liued in this Parish I haue published a Volume of 80 Sermons preached by my Father, and haue prepared 60 more, which are licensed, and entered in the Printers halle, which is, as farr as I can driue them vntill the times allter' ${ }^{\prime}$; was encouradged to vndertake this worke, by the learnedest men in the kingdome, of all professions, and was often told, that I shoud deserue better by doinge soe, then by keepinge them to my owne vse, for by this meanes, I did not only preach to the present adge, but to our childrens children; Sr, I write this to you, that you may iudg what a sad condition a Scholler is in, when at a publicke vestry, in this Parish, I was told by a pittifull ignorant Baker, I was an idle man and neuer preached

$$
\begin{gathered}
\text { your humble seruant } \\
\text { Jo: Donne }
\end{gathered}
$$

A fourth presentation copy, with a letter on the fly-leaves dated Couen Garden, London, Julie 29, I 649, was sent to " $\mathrm{S}$ Constantine Huygens, Knight," translator of Donne's poems (see no. 85); this copy belonged formerly to Dr Grosart. A fifth copy, also accompanied by a letter, was presented to "J. Marckham" (Cat. of Heber Lib., pt. viii, no. 728).

Biathanatos was reprinted by an anonymous publisher in $\mathrm{I} 700$, but since that date its publication has not been undertaken ${ }^{2}$.

1 See p. 147 of present work.

2 An examination and refutation of Biathanatos is to be found in A full enquiry into the subject of Suicide. By the Rez. Charles Moore. (London. 1790. $8^{\circ}$.) Vol. 1. pp. 83-103, and Vol. II. pp. I-tI. 


\section{BIA $\Theta A N A T O \Sigma$. \\ $A$ \\ DECLAR ATION OE THAT \\ PAR ADOXE, \\ OR \\ THESIS, that}

Selfe-bomicide is nor fo Naturally Sinne, that it may never be otherwile.

$$
\text { WHEREIN }
$$

The Nature, and the extent of all thofe Lawes, which feeme to be violated by this Act, are diligenely furveyed.

Writien by 10 H $\mathrm{N}$ DON N $\overline{\text { an }}$ who afterwards received Orders from tbe Church of England, and dyed Deane of Saint Pauls, London.

Jo: Saresb. de nugis Curial. Prolog.

Non orania verse effe froficcor. Sed legentium ufibus infervirr.

Publithed by Authoritie.

$\angle O N D O N$

Printed by fohn $D$ aro fox,

Title-page of no. 47 . 


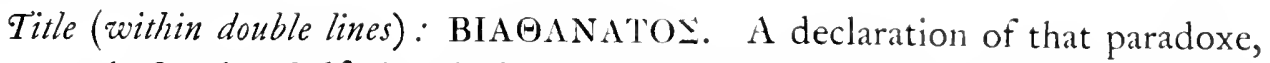
or thefis, that Selfe-homicide is not fo Naturally Sinne, that it may never be otherwife. Wherein The Nature, and the extent of all thofe Lawes, which feeme to be violated by this Act, are diligently furveyed. [rule] Written by Iohn Donne, who afterwards received Orders from the Church of England, and dyed Deane of Saint Pauls, London. [rule] Jo: Saresb. de nugis Curial. Prolog.

Non omnio vera cofe proffteor. Sed legentium ufibus infervire.

Publifhed by Authoritie. [rule]

London, Printed by John Dawfon,

Collation: $\boldsymbol{I}^{4}\left({ }^{*}\right)^{2} \mathrm{~A}^{4} \mathrm{~A}-\mathrm{Z} \mathrm{Aa}-\mathrm{Dd}^{4} \mathrm{Ee}^{2} ; 120$ leaves.

Contents: $\boldsymbol{I}_{1}$ blank; $\boldsymbol{\Phi}_{2}$ title; $\boldsymbol{I}_{3}-\boldsymbol{\Phi}_{4}$ dedication $\mathcal{T}_{0}$ the Right Honourable the Lord Philip Harbert signed by Io. Donne [jun.]; $\left({ }^{*}\right) \mathrm{I}-\left({ }^{*}\right)_{2}$ Authors cited in this Booke; $\mathrm{A}_{\mathrm{I}}-\mathrm{A}_{4}\left(\mathrm{~A}_{2}\right.$ with sign. I $_{2}$ ) contents; $\mathrm{A}_{\mathrm{I}}-\mathrm{B}_{4}$ (pp. I-I6) contents; $\mathrm{C}_{\mathrm{I}}-\mathrm{C}_{4}$ (pp. 17-24) The Preface, Declaring the Reafons, the Purpole, the way, and the end of the author; DI-Ee2 (pp. 25-2I8 [should be 220]) text, at bottom of Ee2b Imprimatur. Io: Rushworth. 20. Sept. 1644.

Note: Pp. 193-220 are numbered 191-218.

Copies: BM, ULC (3), BLO.

Cambridge Colleges: Emmanuel, St John's.

Edmund Gosse (in original sheep binding with printed label on back).

8 BIAOANATOS.

$4^{\circ} \cdot 16$ 16

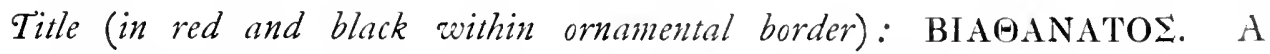
declaration of that paradoxe, or thefis, That Self-homicide is not fo naturally $\operatorname{Sin}$, that it may never be otherwife... [rule] Written by John Donne, who afterwards received Orders from the Church of England and dyed Deane of St Pauls, London. [rule] ...Publifhed by Authority. [rule]

London, Printed for Humphrey Mofeley, and are to be fold at his fhop at the Princes Armes in St Pauls Churchyard. 1648.

Collation, Contents : As in no. 47.

Note: The same sheets as in no. 47 , with cancel title-page.

J. D. 
Copies: BM (2), ALE.

Cambridge Colleges: Clare, King's, Magdalene (Pepys Library), St Catharine's, Trinity (4).

Oxford Colleges : All Souls, Christ Church, Corpus Christi, St John's.

Lincoln Cathedral Library.

John Rylands Library, Manchester.

G. L. Keynes; J. M. Keynes.

49 BIAAANATOS.

8o. $\mathbf{1} 700$

Title (within double lines): BIAOANATOE. [rule] A declaration of that Paradox, or Thefis, that Self-Homicide is not fo Naturally Sin, that It may never be Otherwife. Wherein, The Nature, and the Extent of all thofe Laws, which feem to be Violated by this Act, are Diligently Surveyed. [rule] Written by John Donne; Who afterwards Received Orders from the Church of England; and Died Dean of St. Paul's, London. [rule]

Non Omnia zera effe profteor, fed legentium ufibus infervire.

Jo. Saresb. de nugis Curial. Prolog.

[rule] London: Printed in the Year, I 700.

Collation: $\mathrm{a}^{8} \mathrm{~A}-\mathrm{N}^{3} \mathrm{O}^{4} ; \mathrm{I} \mathrm{I} 6$ leaves.

Contents: a I title; a2 dedication; a 3 authors; a4-A8 contents; $\mathrm{BI}-\mathrm{B}_{4}$ (pp. I-vin) preface; $\mathrm{B}_{5}-\mathrm{O}_{3}$ (pp. 1-I90) text; $\mathrm{O}_{4}$ blank.

Copies: BM, ALE.

Christ's College, Cambridge.

Oxford Colleges: Christ Church, Merton.

Cosmo Gordon; G. L. Keynes. 
ESSAYS IN DIVINITY 


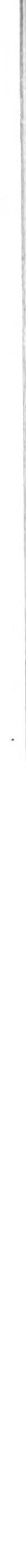




\section{ESSAYS IN DIVINITY}

\section{Bibliographical Preface}

The Essays in Divinity were written by Donne about the year I6r 4 or I6I 5. The editor, John Donne the younger, states in his preface " that they were the voluntary facrifices of feverall hours, when he had many debates betwixt God and himfelf, whether he were worthy, and competently learned to enter into Holy Orders," but Mr Gosse regards them (ii. 63) as nothing more than scholastic exercises and conjectures that "they were written to be laid before the Archbishop as a proof of the soundness of Donne's orthodoxy and the breadth of his learning." The four prayers, however, with which the volume ends, have a much greater emotional and biographical value, and are a more genuine record than the Essays of Donne's transition from a lay to a clerical life.

The volume was printed in $165 \mathrm{I}$, but it is doubtful if it was ever issued separately. It almost invariably occurs bound up with the Juvenilia of I 652 under the title of Paradoxes, problems, effayes, characters etc., and as is shewn elsewhere ( $p .50$ ) formed part of this volume. It is nevertheless quite possible that a few copies were issued separately in I65 I, although I have not yet seen a volume in contemporary binding containing the Essays alone; it is likely that such copies would have the leaf $\mathrm{A}_{3}$ intact, which has been cancelled in all the examples known to me and may have contained the original dedication of the Essays in Divinity, addressed, perhaps, not to Lord Newport, to whom the volume of 1652 is inscribed, but to some other patron of the younger Donne. Copies of the Essays occur separately in recent bindings, but this is probably owing to the fact that their owners believed them to form an independent volume, and they are of no value as evidence of a separate issue ${ }^{1}$.

The Essays in Divinity have only once been reprinted, edited by Dr Jessopp, in 1855 .

1 A copy, for instance, in the library of Mr Edmund Gosse, in modern binding, has at the end a catalogue of $8 \mathrm{pp}$. of books printed for Humphrey Moseley, publisher of the Paradoxes, Problemes, etc. of 1652, suggesting that the two were originally issued together. 
50 ESSAYES IN DIVINITY.

12. 1651

Title (within ornamental border) : Effayes in divinity; By the late $\mathrm{D}^{\mathrm{r}}$ Donne, Dean of St Paul's. Being Several Difquifitions, Interwoven with meditations and prayers: [rule] Before he entred into Holy Orders. [rule] Now made publick by his Son J. D. D ${ }^{\mathrm{r}}$ of the Civil Law. [rule] London, Printed by T. M. for Richard Marriot, and are to be fold at his Shop in $\mathrm{S}^{t}$ Dunftan's Church-yard Fleet-ftreet. I $65 \mathrm{I}$.

Collation: $\mathrm{A}^{4} \mathrm{~B}-\mathrm{K}^{12} \mathrm{~L}^{4}$; I 16 leaves.

Contents: A I blank; A2 title; [A3 cancelled]; $\mathrm{A}_{4}$ To the Reacier; $\mathrm{B}_{1}-\mathrm{K}_{1} \mathrm{I} a$ (pp. I-213) Effayes; KI $\mathrm{K}_{1}$-L4 (pp. 214-224) Prayers.

Note: Printed by Thomas Maxey (1637-1657).

Copies: BM (2), BLO.

Trinity College, Cambridge.

Christ Church, Oxford.

Edmund Gosse; G. L. Keynes.

Essays in divinity by John Donne, D.D. some time Dean of St. Paul's. Edited by Augustus Jessopp, M.A. of St. John's College, Cambridge. London: John Tupling, 320 Strand. I 855 . I $2^{\circ}$. pp. v-lxxiv $+[2]+245+[7]$. 
LETTERS 


\section{LETTERS}

\section{Bibliographical Preface}

The great majority of those of Donne's letters that have survived, have been preserved through the energy of his son, John Donne, D.C.L. A few had been printed by Marriott in the early editions of the poems. Later, in I65I, the younger Donne issued a volume containing one hundred and twenty-nine Letters to severall persons of honour; it would be untrue to say that these letters were edited by him, since they were merely thrown together in any order, for the most part without dates, and were in addition very carelessly printed. Nevertheless they have much literary and biographical importance and become of great interest when the patient scholarship of a present-day editor has assigned to them their proper dates and positions in relation to the events of Donne's life. This necessary editing has been done by Mr Gosse, and in his Life and Letters of Donne, London, I 899 (no. I 26), the letters can be read with more appreciation than had previously been possible. The younger Donne further increased our obligations to him by "editing" in I 660 with equal carelessness a collection of letters which had been made by Sir Tobie Matthew; this collection includes, among a number of letters to and from Donne, twenty-five from him which had not been printed before, and the majority of these have been incorporated by $\mathrm{Mr}$ Gosse in his book already mentioned. Nine new letters were printed by Tomlins in his annotated edition of Walton's Life, I 852. Finally Mr Gosse himself was able to add from manuscript sources eighteen letters which had not previously been printed, so that his volumes contain the only authoritative collection of Donne's letters that has yet been made. A few more letters, also used by Mr Gosse, have been gathered from other sources and are recorded in the entries following. There are still a few more which have not been printed; the copyright of these has been acquired by the Clarendon Press and they will be included in Professor H. J. C. Grierson's projected edition of Donne's letters'.

1 Contemporary copies of five long letters by Donne (four closely written pages, folio) were sold at Puttick and Simpson's on Dec. 19, 1855. I do not know whether these were published letters or not, or their present whereabouts.

J. D. 
52 POEMS.

Tille: Poems by J. D....1633 [see no. 78]

Letters : Eleven prose letters were printed among the Pocms of I633 (see pp. I08-i I I, nos. 79,88 , and $158-166)$. These were reprinted in all later editions of the Poems up to I719. Nos. 159-166 appear also among the Letters of I65I.

53 POEMS。

8o. $\quad 1635$

Title: Poems, by J. D.... I635 [see no. 79]

Letters: Four new letters were added in this edition to those already printed in the Poems of 1633 (see p. I 4 , nos. 20-23); these four appear in later editions of the Poems up to 1719 and among the Letters of 1651 .

54 LXXX SERMONS.

Fo. 1640

Title: LXXX fermons preached by...Iohn Donne,...MDcxL [see no. 29]

Letter: In Walton's Life and Death of Dr. Donne.

On B5t: ['To George Gerrard] January 7. I630 (Porms, I635, no. 23; Letters, I651, no. 87; Walton's Life, 1658, no. 1; Gosse, ii. 268).

Note: Some passages are here omitted from the letter.

55 LETTERS.

$4^{\circ} \cdot 1651$

Title: Letters to feverall perfons of honour: written by John Donne Sometime Deane of $\mathrm{S}^{\mathrm{t}}$ Pauls London. [rule] Publifhed by John Donne $\mathrm{D}^{\mathrm{r}}$. of the Civill Law. [rule]

London, Printed by J. Flefher, for Richard Marriot, and are to be fold at his fhop in $\mathrm{S}^{\mathrm{t}}$ Dunftans Church-yard under the Dyall. ${ }_{1} 6_{5} \mathrm{I}$.

Collation: $\mathrm{A}-\mathrm{Z} \mathrm{Aa}-\mathrm{Sf}^{4} ; \mathrm{I} 64$ leaves.

Contents: A I blank; A2 title; $\mathrm{A}_{3}-\mathrm{A}_{4}$ The Epiftle Dedicatory To the moft virtuous

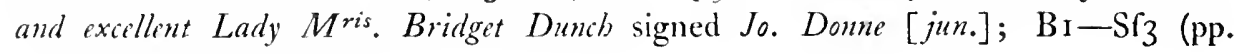
$\mathrm{I}-3 \mathrm{I} 8)$ text; $\mathrm{Sf}_{4}$ blank.

Frontispicce: Inserted between Ar and A2. A bust of Donne at the age of 59 within an oval, $12 \times 9.5 \mathrm{~cm}$., engraved by Pieter Lombart after the oil-painting now at the Deanery of St Paul's. The whole engraving measures $15.5 \times 10 \mathrm{~cm}$., and is inscribed on a cloth hanging beneath the portrait: 
Viri feraphici Joannis Dome Qua-

dragenarii Effigies r'era, Qui post

eam cotatem Sacris initiatus Ec-

cleffer Sii Pauli Deconus obiit.

$$
\text { Año }\left\{\begin{array}{l}
\text { Dōm } \mathrm{I}_{3} \mathrm{3}^{\circ} \\
\text { Etatis suce } \quad 59^{\circ}
\end{array}\right.
$$

The engraving is signed at the right-hand bottom corner: Lombart fiulp. A londre.

Letters :

PAGE

I. To the worthieft Lady Mrs. Bridget White. Strand S. Peters day at nine. [29 June I610 !] (Gosse, i. 234) ${ }^{1}$

2. To the worthieft Lady Mrs B[ridget] W[hite] Strand S. Peters day at + . [ 16 r 0 ? ?] (Gosse, i. 235)

3. To the fame. Novemb. 8 [1610 ?] (Gosse, i. 235)

4. To the Honourable Lady Mrs B[ridget] W[hite] [July I6ro] (Gosse, i. 236)

5. To the Honourable L. the Lady Kingfmel upon the death of her hufband. At my poor houfe at S. Pauls. 26. Octob. I624. (Walton, 1658, no. 5; Tobie Matthew collection, no. 4; Gosse, ii. 2 Io)

6. To my honoured friend Sr. T[homas] Lucey. From Micham my clofe

prifon ever fince I faw you, 9 Octob. [1607] (Gosse, i. 1 73)

7. To the Nobleft Knight Sr. Edward Herbert L. of Cherbury; fent to him with his book Biathanatos. [April 1619] (Gosse, ii. 125. MS. in Bodleian)

8. To Sr. Robert Carre [Ker] now Earle of Ankerum, with my Book Biathanatos at my going into Germany [April 1619] (Gosse, ii. 124)

9. To the Counteffe of Bedford [C. I6I3] (Gosse, ii. +2)

10. To the right honourable the Countefs of Montgomery [April I6I9] (Gosse, ii. 123. MS. extant)

I1. To Sir H[enry] R [Goodyer] [I609 ?] (Gosse, i. 22.5)

12. To Sir H[enry] G[oodyer] [I608 ?] (Walton, 1658, no. 4; Gosse, i. 195) 3 I

13. To my worthy and honoured friend Mr George Garet [Gerrard] [I6I 4 ] (Gosse, ii. 48)

14. To Mr. George Garet [Gerrard] [1609 !] (Gosse, i. 232)

15. To Mrs. Martha Garet [Gerrard] [16I3] (Gosse, ii. I7)

16. To Sir Thomas Roe [1612 ?] (Gosse, ii. II)

${ }^{1}$ Not in the Tobie Matthew collection as stated by Mr Gosse. 
Letters :

17. To all my friends: Sir H[enry] Goodere [16 12 ?] (Walton, I658, no. 2 ; Gosse, ii. 7)

I8. To Sir H[enry] Goodere [Sept. I608] (Walton, I658, no. 3; Gosse, i. I 90)

I9. To Sir H[enry] Goodere [ I 16 I I] (Gosse, i. 239)

20. To the fame [1608 $\vdots]$ (Gosse, i. 193)

21. To Sr H[enry] G[oodyer] [1609] (Poems, I633, no. 163; Gosse, i. 2 I 8)

22. [To a Perion of Honour] Firft Saturday in March 160\%. (Gosse, i. 181) 6 I

23. To the Countefle of Bedford [1609] (Poims, 1633, no. 164; Gosse, i. 217 )

24. To the Honourable Knight Sir H[enry] Goodere. From your houfe at Micham friday morning [1609] (Gosse, i. 223)

25. To Sir H[enry] G[oodyer ?] [1608 ?] (Poems, 1633, no. 166; Gosse, i. I 83. Probably not to Goodyer)

26. To Sir G. F. [April 1612] (Gosse, i. 305)

27. To Sir H[enry] G[oodyer] [1608] (Poems, I633, no. I65; Gosse, i. 185 )

28. To the Honourable $\mathrm{K}^{\mathrm{t}} \mathrm{Sr} \mathrm{H}$ [enry] Goodere one of the Gent. of his Majefties privy Chamber. From my lodging in the Strand, whither I thall return on Munday, is June 1607 (Gosse, i. I 56)

29. To Sr H[enry] G[oodyer] [July 1623] (Gosse, ii. I79)

30. To Sir H[enry] G[oodyer] [1607?] (Pocms, 1633, no. I6 I ; Gosse, i. I69)

31. To your felfe [George Gerrard] Spa 26 July here [ 6 July] I6I2. (Gosse, i. 312)

32. To my Lord G. H. [? George Hastings] [Norember I6 I I] (Gosse, i. 283)

33. To Sir H[enry] G[oodyer] [1607] (Poems, I633, no. I60; Gosse, i. 1 77)

34. To my very true and very good friend Sir Henry Goodere [April I6 5 ?] (Gosse, ii. 77)

35. To Sir G[eorge] M[ore] [c. 1604] (Gosse, i. I 22)

36. To Sr H[enry] G[oodyer] [1609] (Poems, 1633, no. 159; Gosse, i. 227)

37. To your felfe [George Gerrard] 'Tuefday [I6I3] (Gosse, ii. I 4)

38. 'To Sir H[enry] G[oodyer] Micham, 15. Auguft. 1607. (Poems, I633,

no. I62; Gosse, i. 168)
39. To my moit worthy friend Auguft [1609] (Gosse, i. 216)

40. 'To Sir I[ohn] H[arington] 6 Aug. 1608. (Gosse, i. 188)

39. To my molt worthy friend Sir Henry Goodere. Micham the 14

4. To Sir H[enry] Wootton [16 1 2 i] (Gosse, i. 290)

42. To the Honorable Knight Sir H[enry] Goodere. Paris the 9 Apr. I6r2. here. (Gosse, i. 295) 
Letters:

PAGE

43. To Sir H[enry] Wotton [probably to Sir Henry Goodyer] Octob. the $4^{\text {th }}$ 1622. almoft at midnight. (Gosse, ii. I69)

44. A. V[ueftra] Merced. [=To your Worship; probably to Sir Henry

Goodyer] [1608] (Gosse, i. 214 )

45. To the beft Knight Sir H[enry] Wootton. March 1 4. I60\%. (Gosse, i. 179 )

46. To Sir H[enry] G[oodyer] [November I608] (Gosse, i. I98)

47. To the Honourable Knight Sir H[enry] Goodere [1607 ?] (Gosse, i. 1 54)

140

143

$1+6$

48. To the Honourable Knight H[enry] G[oodyer] I 3 Decemb. [I6 I4] (Gosse, ii. 64)

148

49. To Sir H[enry] G[oodyer] Peckham Monday afternoon [i6o9?] (Gosse, i. 2 1 3)

50. To the Honourable Sir R[obert] D[rury] [1614 ?] (Gosse, ii. 36)

151

5I. To the Honourable Knight Sir H[enry] Goodere. Aug. 30 I6II. [1621] (Gosse, ii. I4 I)

52. To his honourable friend $\mathrm{Sr} \mathrm{H}$ [enry] G[oodyer] Micham, Thurfday

late [1609] (Gosse, i. 22 I)

53. To Sr T. H. [? Sir Thomas Lucy] [5 October I62 I] (Gosse, ii. I 49)

54. To Sir H[enry] G[oodyer] i 4 March [16i t] (Gosse, ii. 37)

55. To the Honourable Knight Sir H[enry] G[oodyer] Aug. I 9 [I6It] (Gosse, ii. 49)

56. To Sir H[enry] Goodere at Polefworth. 9 Martii [I6I9] (Gosse, ii. I 2 I)

57. To the beft Knight Sir H[enry] G[oodyer] 26 Febr. I62 I [1622] (Gosse, ii. I 57)

1 76

58. To my beft of friends Sir H[enry] G[oodyer] Monday at night [Auguft I613] (Gosse, ii. 18)

59. To my worthy friend G. K. Jan. I9 [16I3] (Gosse, ii. 24)

6o. To Sir G. B[rydges ?] [Feb. I6It ?] (Gosse, ii. 35)

6i. To the Honourable Knight Sir G. P. [Sir Henry Goodyer] 18 Octob. I622. (Gosse, ii. I 70)

62. To my much honoured friend $\mathrm{Sr} T$ [homas] Lucy [Bruffels] Aug. I6 here. 1622. (Gosse, i. 314)

63. To the honourable Knight Sir H[enry] G[oodyer] 8 Decemb. [I6I4] (Gosse, ii. 66)

64. To my good friend $\mathrm{Sr} \mathrm{H}$ [enry] $\mathrm{G}$ [oodyer] Friday 8 in the morning [ 1608 !] (Gosse, i. 2 I3)

65. To Sir H[enry] G[oodyer] Vigilia St Tho. [Dec. 20] I6I4. (Gosse, ii. 67)

66. To the worthy Knight Sir 'Tho. Lucy. I I Octob. I62 I. (Gosse, ii. I 50) 199 
Letters :

67. To Sir G. B[rydges i] Decemb. 23 [1613] (Gosse, ii. 30)

68. To Sir H[enry] Goodere [1620 ?] (Gosse, ii. I 38)

69. To Sir H[enry'] G[oodyer] [I608] (Gosse, i. I 82)

70. To Sir T[homas] R[oe] Micham, the laft of I607. as I remember [i.e. March 24, I608] (Gosse, i. I 82)

71. To Sir Henry Goodere [? date] (Gosse, ii. 372)

72. To my good friend G. H. I2. Decemb. I600. (Gosse, i. 93)

73. To your felf [George Gerrard] At my Micham Hofpitall, Aug. Io. [1608 ?] (Gosse, i. I 89)

206

74. To the gallant Knight Sir Tho. Lucy. [probably to Sir Henry Goodyer]

Drury houfe the 22 of Decemb. I607 [ 1617 ] (Gosse, ii. I I 7)
To Sir H[enry] G[oodyer]

75. To Sir H[enry] G[oodyer] $2+$ Septemb. [ I622] (Gosse, ii. I 68)

76. To Sir H[enry] G[oodyer] Pyefford [Pyrford] 3 a clock juft as yours came [1604] (Gosse, i. I 28)

77. To Sir H[enry] G[oodyer] [July I 609] (Gosse, i. 230)

78. To Sir H[enry] G[oodyer] [March I615] (Gosse, ii. 72)

79. To Sir Thomas Lucy +. Apr. 16 19. (Gosse, ii. I26)

8o. To the honourable Knight Sr Henry Goodere. Micham Wednefday [ I608] (Gosse, i. 224)

8I. To Sir H[enry] G[oodyer] at Polefworth [Oct. 25, I 62 I] (Gosse, ii. I 52)

82. To my worthy friend F. H. [? to George Herbert] [c. I628] (Gosse, ii. 255)

83. To Sir H[enry] G[oodyer] [Sept. I622] (Gosse, ii. I66)

84. To the worthieft Knight Sir Henry Goodere [Dec. 21, 1625] (Gosse, ii. 226)

85. To my honoured friend G[eorge] G[errard] Efquire. Paris the 14 of Aprill, here, I6I2. (Poems, I635, no. 21 ; Gosse, i. 303)

86. To my honoured friend G[eorge] G[errard] Efquire [Aberyhatch Nov. 2. I630] (Poems, I635, no. 22; Gosse, ii. 266)

87. [To George Gerrard] [Jan. 7, I630] (Poems, I635, no. 23; 80 Sermons, ı́ ło; Gosse, ii. 268)

88. To the Lady G[rymes ?] [Amiens, Feb. 7, I6I2] (Poems, I635, no. 20; Gosse, i. 289)

89. To your felfe [George Gerrard] [Paris April 9, I6I2] (Gosse, i. 300)

90. To the Honourable Knight, Sir Robert Karre [Ker] [Feb. I624] (Gosse, ii. I 89)

91. To your felfe [George Gerrard] [July 16 12] (Gosse, i. 310)

92. [To George Gerrard i] [Paris, April I 4, I6 I2] (Gosse, i. 301)

93. To my Honoured friend Mr George Gerrard [Oct. I6 I 2 ?] (Gosse, ii. I2) 
Letters:

PAGE

94. To my very worthy friend Mr George Gerrard [March? 4, 16 I 2

Paris] (Gosse, i. 294)

259

95. To your felfe [George Gerrard] [Amiens, Feb. I6I2] (Gosse, i. 286) 262

96. To my Honoured friend M. George Garrat [Gerrard] [Amiens, Dec. I6 I I] (Gosse, i. 285)

97. To your fair fifter [Gerrard's] [Spa, July, I6 I 2] (Gosse, i. 3 I I)

264

266

98. To the Honourable Knight Sir Henry Goodere [probably to the Earl of Somerset] [1614] (Gosse, ii. 5I)

267

99. To the Honourable Knight Sir Robert Karre [Ker] [I6 I 3] (Gosse, ii. 26)

270

I 00. To the Honourable Knight Sir Robert Karre [Ker] Gentleman of his

Highnefles Bedchamber. I7 Aprill. [I6I5] (Gosse, ii. 75)

$27 \mathbf{I}$

I01. To the Honourable Knight Sir Robert Karre [Ker] [May I6I4] (Gosse, ii. 45)

102. Ditto [1610 ?] (Gosse, i. 239)

103. Ditto. 25. Julii [1622] (Gosse, ii. 165)

104. Ditto. [1622] (Gosse, ii. I64)

105. Ditto. 2. Aug. 1622. (Gosse, ii. 165)

ı06. To my Honoured Friend, Mafter George Gherard [Gerrard] [16 13] (Gosse, ii. 29)

107. To my very much honoured friend George Garrard [Gerrard] Efquire at Sion [Oct. 1630] (Gosse, ii. 265)

I08. To my very much refpected friend $M^{r}$ George Garrard [Gerrard] [16 14] (Gosse, ii. 50)

I09. To my Honoured friend M. George Gherard [Gerrard] over againft Salifbury houfe [ 1622 ?] (Gosse, ii. 172 )

1 10. To my very much Honoured friend George Garret [Gerrard] Eiquire [Abury Hatch, Dec. I630] (Gosse, ii. 267)

I1 I. To the Honourable Knight Sir Robert Karre [Ker], Gentleman of his Highneffes Bed-chamber. 27 January. [1615] (Gosse, ii. 71)

273

$27+$

276

278

279

280

28 I

$28_{3}$

285

286

288

1 12. To the Right Honourable the Lord Vifcount of Rochefter [1612]

(Tobie Matthew collection, no. 22; Gosse, ii. 22)

1 13. To the Honourable Knight Sir Robert Karre [1610 !] (Gosse, i. 238) 292

I 14. To your lelfe [George Gerrard] [ [1612] (Gosse, ii. I0)

294

I 1 5. To the Honourable Knight Sir Robert Karre [Ker], Gentleman of his Highneffes Bedchamber [June? I6 I 5] (Gosse, ii. 8I)

I 16. To the Honourable Knight, Sir Robert Karre [Ker] [I6I 4 !] (Gosse, ii. 39)

I17. Ditto. 20. Mar. [1614] (Tobie Matthew collection, no. 18; Gosse, ii. I 5) 
Letters :

I 8. Ditto. [? date] (Gosse, ii. 372)

I19. Ditto. 4 Novemb. [1616] (Gosse, ii. 87)

120. Ditto. [? date] (Gosse, ii. 372)

121. To your felfe [George Gerrard] Drury houfe, 23 Sept. [1613] (Gosse, ii. 29)

122. To the Right Honourable Sir Robert Karre [Ker] [April 2, 1627] (Gosse, ii. 243)

123. To the Right Honourable Sir Robert Karre [Ker], at Court [April 1627] (Gosse, ii. 246)

124. Ditto. [April, 1627] (Gosse, ii. 244)

125. Ditto. [April 3, 1625] (Gosse, ii. 220)

126. Ditto. [March, 1625 ?] (Gosse, ii. 216)

127. Ditto. [April 2, 1625] (Gosse, ii. 219)

128. Ditto. + Jan. 1626. (Gosse, ii. 24I)

129. To my Noble friend Mris Cokain at Arburne. 15 Jan. 1630. Abreyhatch. (Gosse, ii. 269)

Note: The portrait by Lombart, which appears in this and the succeeding edition of the Letters, is very frequently missing. The same plate was used in two editions of IValton's Lives, 1670 and 1675 , but by this date it had become worn and the impressions are poor.

Copies : BM (2), BLO, ALE.

Cambridge Colleges: Magdalene, St John's (no portrait), 'Trinity.

Christ Church, Oxford.

Salisbury Cathedral Library (Izaak Walton's copy, with his autograph in two places; also that of his son, Canon Izaak Walton, dated 1683 ).

Edmund Gosse; G. L. Keynes; J. M. Keynes.

Title: Letters to feverall perfons of honour :...

London, Printed by J. Flefher, and are to be fold by John Sweeting, at the Angel in Popeshead-Alley. I654.

Collaition, Contents, Frontispiece, Letters: As in no. 55.

Note: The same sheets as in no. 55 , with cancel title-page.

Copies: BM (2).

Cambridge Colleges: Corpus Christi, 'Trinity.

G. L. Keynes; J. M. Keynes. 
Title (within single line): Cabala. Mylteries of State, in letters of the great Minifters of K. James and K. Charles. Wherein Much of the publique Manage of Affaires is related [rule] Faithfully Collected by a Noble Hand. [ornament between rules]

London, Printed for M.M. G. Bedell, and T. Collins, and are to be fold at their Shop at the Middle-Temple Gate in Fleetftreet. I654.

Collation: $\mathrm{A}^{8} \mathrm{~B}-\mathrm{Z} \mathrm{Aa}-\mathrm{Zz}^{4} ; 192$ leaves.

Contents: $A_{1}$ blank; $A_{2}$ title; $A_{3}-A_{4}$ preface; $A_{5}-A_{8}$ contents; $\mathrm{B}_{1}-\mathrm{Yy}_{2}$ a (pp. 1-347) text; Yy2b blank; $\mathrm{Y}_{3} 3-\mathrm{Zz}_{4}$ index.

Letters : Donne's letters are as follows :

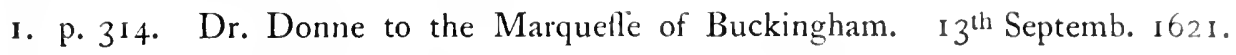
(Gosse, ii. 147)

2. p. 315. Dr. Donne to the Duke [of Buckingham] [1623-4] (Gosse, ii. 207; Tobie Matthew collection, no. 9)

Note: In the same year $A$ fupplement of the Cabala was issued, and a general titlepage: Cabala: five forinia facra...1654., was inserted between $A_{1}$ and $A_{2}$ of the present work.

Copies : BM etc.

8 WALTON'S LIFE OF DONNE. I $2^{\circ} . \quad 1658$

Title: The Life of John Donne... I658. [see no. I06]

Letters :

I. p. 100. [To George Gerrard Jan. 7 1630] (Poems, 1635, no. 23; 80 Sermions, I640; Letters, I651, no. 87; Gosse, ii. 268)

2. p. 122. To all my friends: Sir H. Goodere [1612] (Letters, 1651, no. 17; Gosse, ii. 7)

3. p. 128. To Sir H. Goodere [Sept. 7, 1608] (Letters, 1651, no. 18; Gosse, i. 190)

4. p. 134. To Sir H. Goodere [1608 ?] (Letters, I65 I, no. 12; Gosse, i. 195)

5. p. I4I. To the Honble Lady, the Lady Kingsmel, upon the death of her Husband. 26 Octob. 1624. (Letters, 1651, no. 5; Gosse, ii. 210)

Note: Part of no. 3 was incorporated in the edition of Walton's Lives published in 1670 ; nos. 2, 4, and 5 were omitted. Walton's version of no. 3 is different from that of the Letters of 1651 .

J. D. 
Title: A collection of letters, made by $\mathrm{S}^{\mathrm{r}}$ Tobie Mathews $\mathrm{K}^{\mathrm{t}}$. With a Character of the moit Excellent Lady, Lucy, Counteffe of Carleile: By the fame Author. To which are Added many Letters of his own, to feverall Perfons of honour, Who were Contemporary with him. [rule] London, Printed for Henry Herringman, and are to be fold at his Shop, at the fign of the Anchor in the Lower walk in the New Exchange. I 660 .

Collation: $[\mathrm{a}]^{2} \mathrm{~A}-\mathrm{Z} \mathrm{Aa}^{3} \mathrm{Bb}^{4} ; 198$ leaves.

Contents: [a1] blank; [a2] title; $\mathrm{A}_{1}-\mathrm{A}_{3}$ dedication $\mathcal{T}_{0}$ the Right Honourable Lucy, Counteffe of Carleile signed by Jobn Donne [jun.]; A 4-A8 The Cbaracter of the moft excellent Lady, Lucy Countefs of Carleile; $\mathrm{B}_{1}-\mathrm{C}_{\mathrm{I}} \tau_{\mathrm{T}}$ the Reader; $\mathrm{C}_{2}-\mathrm{Bb} 3$ (pp. I-356) text; Bbt blank.

Frontispiece: A bust of the subject in an oval, $9 \times 7 \mathrm{~cm}$., inscribed below: The lively Portraieture of $\mid S^{r}$ Tobie Matbewes $K n^{t} \mid$ James Gammon sculp. The plate-mark measures $1+\times 9.5 \mathrm{~cm}$.

Letters to and from Donne:

PAGE

I. Doctor Dunne, in kindnefse to an abfent Friend.

2. Of the fame to the fame, upon the like occafion.

3. Doctor Dunne, with a kind of labour'd Complement, to a Friend of his.

4. Doctor Dunne writes Confolatorily to a Lady, upon the Death of her Husband ['To the Lady Kingsmell, 26 Oct. I624] (Letters, I65I, no. 5; Gosse, ii. 210)

5. A Letter from one, to the Queen of Bohemia; upon prefentation of a Book of Meditations ${ }^{1}$ to her. [1624] (Gosse, ii. 205)

6. A Letter from the Queen of Bohemia, in anfwer to the former. [I624] (Gosse, ii. 206)

7. A Letter from the fame Perfon to the Queen of Bohemia, upon prefenting of a Sermon² to her. [1626] (Gosse, ii. 233)

8. A Letter from the fame Queen, in Anfwer to the last Letter. [ib.]

9. A Letter from one to the Duke of Buckingham; upon prefenting his Meditations $^{3}$ to him. [1624] (Gosse, ii. 207. Cabala, p. 315)

10. A Letter from the fame Perfon to a Lord, upon prefenting of fome of his work ${ }^{3}$ to him. [162.4] (Gosse, ii. 208)

1 Devotions, $162+$.

2 The first sermon preached to King Charles, 1625. "Derotions, 1624. 
Letters to and from Donne:

PAGE

I1. A Letter from the Lord of Carlile to J. D. therein fignifying the King's pleafure, in having a Sermon ${ }^{1}$ Printed, which was formerly prefented to his Majesty in writing. [1622] (Gosse, ii. 160)

12. A Letter from J. D. to the Queen of Bohemia, with the prefenting of the fame Sermon to her. [Oct. 1622] (Gosse, ii. I61)

13. A Letter from J. D. to Sr. Robert Carre Knight, when he was in Spain; about feverall matters. [1624] (Gosse, ii. I 91)

14. A Letter from the aforeaid J.D. to the aforefaid Sir Robert Carre,
Earl of A. fetting forth his fervant love towards him. [ [ 624] (Gosse,

14. A Letter from the aforefaid J.D. to the aforefaid Sir Robert Carre,
Earl of A. fetting forth his fervant love towards him. [1624] (Gosse, ii. 190)

15. A Letter from J. D. to my Lord's Grace of Canterbury, concerning a third Perfon. [c. 1622] (Gosse, ii. 178)

16. The Anfwer to the fame. [c. 1622]

17. A Letter from J. D. to the Earl of Someriet, thankfully acknowledgeing the Earls Kindnefs to him in his ficknefs, as alfo with a strong proteftation of fervice. [C. 1614] (Gosse, ii. 40)

304

305

307

309

310

3II

18. A Letter from the fame Perion, to a worthie Knight. It confists of much kindnefs and friendhip. [To Sir Robert Ker, 20 March I6I4] (Letters, 1651, no. 117. Gosse, ii. 15)

19. A Letter from the Lord of Doncafter, when he was in France, to Doctor Donne. It confists of much kindnefs and friendfhip. [c. 1622]

20. A Letter from J. D. to the Lord of Somerfet. [c. I6I4] (Gosse, ii. 4I) 3 I3 $3 \mathrm{I}+$

21. A Letter from J. D. to the Lord of Rochefter. It confists of feverall matters, with much kindnefle. [1613] (Gosse, ii. 28)

22. The fame perfon to the Lord of Rochefter. It confists of high Complements, and much kindnefs. [1612] (Letters, 1651, 110. I12; Gosse, ii. 22)

23. A Letter from Doctor Donne, to the fame Lord of Rochefter, of the fame kind. [Oct. 1612] (Gosse, ii. 20)

24. A Letter from Doctor Donne, to the Lord Hay. [16I2] (Gosse, ii. 21) 316

25. A Letter of the Lord of Doncalter, from Bourdeux, to Doctor Donne: wifhing him to referve fome Wine for his Entertainment. I9 May. [1622]

26. Doctor Donne, to his Mother: comforting her after the death of her Daughter. [1616] (Gosse, ii. 88)

27. A Letter from Ben. Johnion to Doctor Donne, in clearing himielf upon a former accufation.

${ }^{1}$ A sermon upon the xx. verse of the 2 . chapter of the Booke of Julges, 1622. 
Letters to and from Donne:

28. A Letter from Doctor Donne to the Lord Hay, acknowledging former courtefies, and cleering himself from an accufation. [c. 1608] (Gosse, i. 201)

29. The fame Perfon, to the Lord Hay. [c. 1608] (Gosse, i. 202)

30. A kind Letter from the Lord Hay, to Doctor Donne.

31. Doctor Dome to the fame Lord, requefting a Courtefie. [1615] (Gosse,

32. A Letter of much kindneffe from Doctor Donne, to Sir Toby Mathew,

from Colleyn. [1619] (Gosse, ii. 136)
33. Doctor Donne to Mrs. Cockaine, occafioned by the report of his death. [1628] (Gosse, ii. 259)

34. A Letter of much kindneffe from Doctor Donne, to the fame friend. [May I628] (Gosse, ii. 256)

35. A Letter between the lame Perfons. [Aug. 24, 1628] (Gosse, ii. 257)

36. A Letter from the aforefaid Doctor Donne to the fame friend, occafioned by the death of her fon. [1629] (Gosse, ii. 260)

37. A Letter between the fame Perfons. [Jan. 1631] (Gosse, ii. 271)

Note: This collection was edited by John Donne, jun., whose name was added to the title-page of the issue of 1692 (see no. 62). "Sir Tobie Matthew was son of Dr. Tobie Matthew, Archbishop of York; he was born in Oxford in 1578, while his father was Dean of Christchurch. During his travels he was reduced to the Romish religion by Father Parsons. This occasioned his absence from England from 1607 to 1617 , when he had leave to return. He was ordered to leave it again in Oct. 1618; but in 1622 was recalled to assist in the match with Spain; and on account of his endeavours to promote it was knighted by King James at Royston, Oct. I0, 1623. He was much cultivated by Lord Bacon, and translated the Essays into Italian. He died at Ghent, Oct. 13, I655." (Transcribed from a MS. note on the fly-leaves of the ULC copy.) Three of Donne's letters (nos. 1-3) in this collection have not been reprinted.

Copies: BM, ULC.

Edmund Gosse; G. L. Keynes.

60 WALTON'S LIFE OF HERBERT.

8. 1670

Title: The life of Mr. George Herbert. [rule] Written by Izaack Walton. [rule] To which are added fome letters Written by Mr. George Herbert, at his being in Cambridge: with others to his Mother, the Lady 
Magdalen Herbert: Written by John Donne, afterwards Dean of

St. Pauls. [rule]

$$
\text { Wifdom of Solom. 4. } 10 .
$$

He pleafed God, and was beloved of him: fo that whereas he lized among finners, he tranflated him.

[rule] London, Printed by Tho: Newcomb, for Rich: Marriott, Sold by moft Bookfellers. M.DC.Lxx.

Collation: $\mathrm{A}^{8+1} \mathrm{~B}-\mathrm{I}^{8} \mathrm{~K}^{2} ; 67$ leaves.

Contents: A I frontispiece; $[\mathrm{A}]^{*}$ leaf inserted, recto with title as above, verso with Imprimatur Sant: Parker April 21. 1670; A2a subtitle to Life; A2b Imprimatur as before; $\mathrm{A}_{3}-\mathrm{A}_{5}$ a [A3 with sign. A 2] (pp. 5-9) verses To...Mr. Izaack W alton... signed Sam: Woolforde; A5b-A6 (pp. I0-12) The Introduction; $\mathrm{A}_{7}-\mathrm{F}_{4} a$ (pp. I3-I I9) The Life; F 4 b blank; F5 subtitle to Letters; F6-KI (pp. I23-I 46 ) $M r$. Herberts Letters and Dr. Donnes Letters; $\mathrm{K}_{2}$ verses On Mr. George Herbert's Book, Intituled, The Temple...by Mr. Crafbaw.

Frontispiece: Bust of George Herbert within an oval, $9.5 \times 7 \mathrm{~cm}$., inscribed below: The Effigies of $M^{r}$ : George Herbert: | Author of those Sacred Poems called $\mid$ The Temple. It is signed: $R:$ White fculp. The whole engraving measures $13.5 \times 8 \mathrm{~cm}$.

Letters : Donne's letters are as follows:

1. pp. 24-26. With the verses To the Lady Magdalen Herbert, of St. Mary Magdalen. Micham, July II. 1607. [?] (Gosse, i. 167)

2. pp. 141-2. To the worthieft Lady, Mrs. Magdalen Herbert. Michin [Micham], July I I. I607. (Gosse, i. I64)

3. pp. 143-4. Ditto. London, July 23. 1607. (Gosse, i. 165)

4. pp. 145-6. Ditto. Auguft 2d. 1607. (Gosse, i. 166)

Note: These letters are also found in the subsequent editions of Walton's Lives, 1670 etc. The title-page printed above, which is an insertion, does not occur in most copies of the book and is not mentioned by Hazlitt. It occurred, however, in a copy, which was recently in my own possession.

Copies: BM, ULC.

Edmund Gosse.

WALTON'S LIVES.

8.. 1670

Title: The Lives [of] Dr. John Donne, Sir Henry Wotton, Mr. Richard Hooker, Mr. George Herbert [rule] Written by lzaak Walton. [rule]... London, Printed by Tho. Newcomb for Richard Marriott. Sold by moft Bookfellers. I670. $8^{\circ}$. 
Letters: In the life of Donne:

I. p. 29. [Probably to Sir Henry Goodere] Aug. Io [1608 ?] (Gosse, i. I 89)

2. p. 29. [To Sir Henry Goodere] Sept. 7 [1608] (Letters, I65 I, no. I 8 ; Walton's. Life, 1658, no. 3; Gosse, i. I90)

3. p. 69. [To George Gerrard. January 7. 1603] (Poems, 1635, no. 23; 8o Sermons, 1640; Letters, 1651, no. 87; Walton's Life, 1658, no. I; Gosse, ii. 268)

With the life of Herbert :

4-7. Letters to Mrs. Magdalen Herbert as in no. 60.

Note: The first of these, which is an extract only, does not appear anywhere else.

The second is here incomplete though it was printed entire among the letters at the end of Walton's Life of Donne, 1658.

62 TOBIE MAT'THEW COLLECTION.

8. 1692

Title: A collection of letters Made By $\mathrm{S}^{\mathrm{r}}$ Tobie Mathews, $\mathrm{K}^{\mathrm{t}}$....Publifhed by the Rev ${ }^{d}$ Dr J. Donne. [rule]

Printed for Tho. Horne, Tho. Bennet, and Francis Saunders; at the Royal-Exchange, St. Paul's Church-yard, and the New-Exchange in the Strand. I692.

Collation, Contents, Frontispiece, Letters: As in no. 59.

Note: A reissue of no. 59 with a new title-page inserted after the original title-page of 1660 .

Copy: ULC.

63 DONNE'S WORKS.

6 vols. 8 o. $\quad 1839$

The Works of John Donne, D.D. [Edited] by Henry Alford... I 839 [see no. 33]

Letters: In vol. vi :

pp. 299-440. Letters to Several Persons of Honour (rearranged by the editor)

pp. 440-44I. Henrico Goodyere (Latin letter from Poems, I633, no. I 58)

64 WALTON'S LIFE.

8. $[1852]$

The Life of John Donne, D.D. ... By Isaac Walton. [edited by T. E. Tomlins, I 852] [see no. I07]

Letters: Several letters from the Loseley MSS. were printed here for the first time :

I. To the Right Worshipful Sir George More, Kt. From my lodginge in $y^{\mathrm{e}}$ Savoy, $2^{\circ}$ Februar. I600-I. (p. 24. Gosse, i. IOI) 


\section{-}

2. To the right wor. Sr. Geo. More, Kt From the Fleete, I Io Febr., I60I. (p. 29. Gosse, i. 104)

3. To the right honble my very good L. and Master, Sir Tho. Egerton, knt., L. keeper of the greate Seale of Englande. Fleete, 12 ${ }^{\circ}$ Febr. I60 I. (p. 30. Gosse, i. 105)

4. To the right wor'pll Sir George More, Knight. From my chamber whither by your favour I am come, 13 feb. I601. (p. 30. Gosse, i. I06)

5. To the right hon. my very good L. and Master Sr Tho. Egerton, knt.... 13 Feb., 160r. (p. 31. Gosse, i. 107)

6. To the right honorable my very good Lord and Master Sr Tho. Egerton, knt. [Feb. 1601] (p. 3i)

7. To the right worshipfull Sr George More, knight. Mar. I60I. (p. 33 . Gosse, i. I 12 )

8. To the right honorable my very good L. and master, $\mathrm{S} r$ Thomas Egerton, knight. Io Martii, 1601. (p. 34. Gosse, i. 114)

9. To the right wor. Sr Robert More, knight at Lothersley. Io Aug. I6I 4. (p. 74. Gosse, ii. 47)

Note: No. 6 above does not seem to have been reprinted by Mr Gosse.

65 CAMDEN SOCIETY.

$4^{\circ} . \quad 1868$

Letters and other Documents illustrating the Relations between England and Germany at the commencement of the Thirty Years War. Second series...Edited by S. R. Gardiner. Printed for the Camden Society. M.DCCC.LXVIII. $4^{\circ}$ pp. xi +194 .

Letter: No. v. pp. 5-6. To Sir Dudley Carleton. Mastrich. 3I Aug. 16I9, stylo vetere. (State Papers, Holland. Gosse, ii. I 43)

CAMDEN SOCIETY. $4^{\circ} \cdot \quad 187 \mathrm{r}$

The Fortescue Papers...Edited...by S. R. Gardiner...Printed for the Camden Society M.Dccc.Lxxi. $4^{\circ}$ pp. $[i v]+x x x v+225$.

Letter: No. crirl. pp. 157-I58. To the Right Honourable my singular good L. the Marquis of Buckingham. 80 August 1621. (Gosse, ii. 140)

67 GOSSE.

8.. I 899

The Life and Letters of John Donne ... By Edmund Gosse ... I 899 2 vols. $8^{\circ}$ (see no. 126 )

Letters: The following letters were printed here for the first time-

I. To my very honest and very assured friend Robert Cotton Esq., at his house 
in Blackfriars. From my prison in my chamber 20th February I601. (i. 109. MS. in BM)

2. [To Sir Henry Goodyer] 23rd February I60I from my chamber at Mr. Haines' house by the Savoy. (i. I 09. MS. in possession of J. H. Anderdon, Esq.)

3. To Robert Cotton, Pyrford. [1603 ?] (i. I23. MS. in BM)

4. [To a brother of Mrs. Donne] Amiens, 7 Febr. here, I6II. (i. 287. From the Loseley MSS.)

5. [To : ] [ 1612$]$ (i. 309. MS. in possession of J. H. Anderdon, Esq.)

6. [To ?] From my Hospital, July 17, 1613. (ii. 16. MS. in possession of J. H. Anderdon, Esq.)

7. [To ?] Sat. I2 Feb. I6 I3. (ii. 33. MS. in possession of J. H. Anderdon, Esq.)

8. To Sir Robert More. At my poor hospital, 28th July 16r 4. (ii. 46. From the Loseley MSS.)

9. [To Sir Robert More] At my poor house, 3 December I6I4. (ii. 60. From the Loseley MSS.)

10. To Sir Henry Marten. At my house at S. Paul's, May 9, I622. (ii. 156. ? source)

I I. To the Right Honourable Sir Thomas Roe, Ambassador for His Majesty of Great Britain to the Grand Seignior. At my poor house at St. Paul's, London, Ist December, I622. (ii. I73. Domestic State Papers, James I)

12. To the Most Honourable and my most honoured Lord, the Marquess of Buckingham [1623] (ii. 176 . Bodleian, Tanner MSS.)

13. [To a lady at the Court of Bohemia] Ist February, I623. (ii. 206. MS. in possession of J. H. Anderdon, Esq.)

14. To the Right Worshipful Sir N. Carew, at Bedington. At my house at St. Paul's, Ist September 1624. (ii. 209. Domestic State Papers)

15. To Sir Nicholas Carew. At my house at Drury House, September $17^{\text {th. }}$ [1624] (ii. 209. Domestic State Papers)

16. To Secretary Conway. At my poor house at Paul's, 7 th December I624. (ii. 213. Domestic State Papers)

17. [To?] At Chelsea, 25th November, 1625. (ii. 222, 310. Domestic State Papers)

18. To Sir Nicholas Carew. At Paul's house, 26th January, 1626. (ii. 232. MS., much damaged, in possession of the Rev. S. Simpson)

68 LETTERS.

Letters to Several Persons of Honour. Edited by C. S. Merrill. New York. I9 I I.

Note : Edition limited to 600 copies. 
OCCASIONAL PIECES

J. D. 


\section{.}




\section{OCCASIONAL PIECES}

\section{Bibliographical Preface}

In this section I have included only those few pieces, which are certainly by Donne and were printed in various books during his lifetime. A few other poems by Donne were printed in books published between 1640 and I675, and these I have recorded in the footnotes to the section containing the collected Poems. A number of other poems, which have been attributed to Donne, though actually spurious or of doubtful authenticity, are to be found in other publications of the seventeenth century, but I have not considered these to be of sufficient importance to be given a place in this bibliography; they will, for the most part, be found recorded in Professor Grierson's edition of the poems.

is VOLPONE.

$4^{\circ} \cdot 1607$

Ben: Ionfon his Volpone Or the foxe...

Printed for Thomas Thorppe. 1607. $4^{\circ}$.

Poem: On A. AmiciJimo, \& meritiffimo Ben: lonfon [signed] I[ohn] D[onne]

Note : First printed among Donne's poems in the edition of 1650 . Found also in The Works of Beniamin Jonson, 1616, F.

10 CORYA'T'S CRUDITIES.

8. 1611

[Coryat's Crudities]...

London, Printed by W. S. Anno Domini 16 I I $8^{\circ}$. 
Popms: Under Panegyricke Verses vpon the Author and his booke.

I. On $\mathrm{d}_{3}-4$. Incipit Ioannes Donne (Oh to what height will loue of greatneffe driue)

2. On d4. In eundem Macaronicon. Explicit loannes Donne (Quot, dos bac, Linguists perfotti, Disticha fairont)

3. On $\mathrm{f}_{5} b$. Incipit Ioannes Donne (Loe her's a Man, worthy indeed to trauell)

Note: No. I was first printed among Donne's poems in the edition of 1649. The second and third are given by Chambers, ii. 289-290, and by Grierson, i. 174, ii. 129 .

7I CORKINE'S BOOK OF AYRES.

1612

A Second Booke of Ayres by William Corkine. 1612 .

Note: This book, a copy of which I have not been able to find, contains two of Donne's poems, Breake of Day and The Baite (Poems, 1633, nos. II 5 and 97), set to music. The settings were transcribed for Prof. Grierson and are printed by him, ii. $55-57$.

72 LACHRYMAE LACHRYMARUM. $4^{\circ} \cdot 1613$

Lachrymæ Lachrymarum or The Spirit of Teares Distilled for the vntymely Death of The incomparable Prince, Panaretus. by Iosuah Syluester. The third Edition, with Addition of His Owne [London Printed by Humfrey Lownes. 16I3] $4^{\circ}$.

Porm: On EI-E2. Elegie On the vntimely Death of the incomparable Prince, Henry. By Mr. Donne.

Note: Reprinted in all the editions of the poems ( 1633 , no. 84) with title "Elegie on Prince Henry."

73 OVERBURIE'S CHARACTERS.

8.. 1615

New and choife characters, of feuerall Authors: Together with that exquifite and vnmatcht Poeme, the wife, Written by Syr Thomas Ouerburie. With the former Characters and conceited Newes, All in one volume. With many other things added to this fixt Impreffion... London Printed by Thomas Creede, for Laurence Line,... I6 $15 . \quad 8^{\circ}$. Prose piece: On F $1 b-F_{2} b$. Newes from the very Countrey, [signed] I[ohn] D[onne] Note : First printed among Donne's poems in the edition of 1650. 
ANNIVERSARIES 



\section{ANNIVERSARIES}

\section{Bibliographical Preface}

The First Anniversarie was composed by Donne in memory of Elizabeth Drury $^{1}$, daughter of his patron Sir Robert Drury of Hawsted in the county of Suffolk. The Funerall Elegie is believed to have been written in I610 at the time of her death and the Anatomie of the World a year later, in I6 I I. To the praise of the Dead and the Anatomy is not by Donne and was probably written by Joseph Hall, who was rector of Hawsted from I 600 to I608. The second Anniversarie was written early in I6 12, but again only $O f$ the progres of the Soule was by Donne, The Harbinger to the Progres being by Hall. Donne's name does not appear in any of the editions recorded below, but their authorship was doubtless well known, and Donne refers to the poems in a letter to George Gerrard, dated April I 4, I6 I $2^{2}$. According to Grierson these editions were printed with increasing carelessness, but when the Anniversaries were reprinted in the collected Poems of I 633 they were more carefully edited; they also appear in all later editions of the Poems. All the separate editions of the Anniversaries contain marginal notes; these were somewhat imperfectly reproduced in 1633 and in later editions were omitted altogether. For further details concerning the Anniversaries, see Gosse, i. 273-278, and Grierson, ii. 178-189, who gives facsimile reproductions of all the title-pages.

1 A contemporary portrait of Elizabeth Drury is reproduced in Gosse, i., facing p. 272.

2 Letters, 165 I, no. 85. 
96

74 AN ANATOMY OF THE WORLD.

80. 16 II

Title (within woodcut border): An anatomy of the World. Wherein, by occafion of the vntimely death of Miftris Elizabeth Drury the frailty and the decay of this whole world is reprefented. [rule]

London, Printed for Samuel Macham. and are to be folde at his thop in Paules Church-yard, at the figne of the Bul-head. An. Dom. i6 I.

Collation: $\mathrm{AB}^{8}$; 16 leaves ${ }^{1}$.

Contents: A I blank; A2 title; $\mathrm{A}_{3}-\mathrm{A}_{4}$ a To the praife of the Dead, and the Anatomy (in italics); $\mathrm{A}_{4} b-\mathrm{B}_{5}$ An anatomy of the $I$ orld (in italics); $\mathrm{B}_{6}-\mathrm{B}_{7} A$ funerall Elegie (in roman type); $\mathrm{B} 8$ blank.

Copy: Library of Lord Ellesmere, Bridgewater House.

75 FIRST AND SECOND ANNIVERSARIES.

8. 1612

First title (within double lines): The Firft Anniuerfary. An anatomy of the World. Wherein, By Occafion Of the vutimely death of Miftris Elizabeth Drury, the frailty and the decay of this whole World is reprefented. [ornament]

London, Printed by M. Bradwood for S. Macham, and are to be fold at his Thop in Pauls Church-yard, at the figne of the Bul-head. I6 I2.

Second title (ditto): The Second Anniuerfarie. Of the progres of the Soule. Wherein: By Occafion Of The Religious Death of Miftris Elizabeth Drury, the incommodities of the Soule in this life and her exaltation in the next, are Contemplated. [rule]

London,... I 6 I 2 .

Collation: $\mathrm{A}-\mathrm{D}^{8}, \mathrm{E}-\mathrm{G}^{\mathrm{s}} \mathrm{H}^{6} ; 62$ leaves.

Contents: A I first title; $\mathrm{A}_{2}-\mathrm{A}_{4} T_{0}$ the praise of the Dead, and the Anatomy (in italics); $\mathrm{A}_{5}-\mathrm{D}_{2}$ (pp. I-44) The Firft Anniuerfary; $\mathrm{D}_{3}-\mathrm{D}_{7}$ (pp. 45-54) A funerall Elegie (in italics); D8 blank except for marginal rules; EI second title; $\mathrm{E}_{2}-\mathrm{E}_{4} a$ The Harbinger to the Progres (in italics); $\mathrm{E}_{4} b$ blank; $\mathrm{E}_{5}-\mathrm{H}_{5} a$ (pp. I49) The Second Anniuerfary; $\mathrm{H}_{5} b-\mathrm{H} 6$ blank except for marginal rules.

Note: The text of The Firft Anniuerfary contains some variations from that of I6I I, and is considered by Grierson to have been somewhat carelessly printed.

1 I am indebted for the collation to Mr Strachan Holme, Librarian at Bridgewater House. 


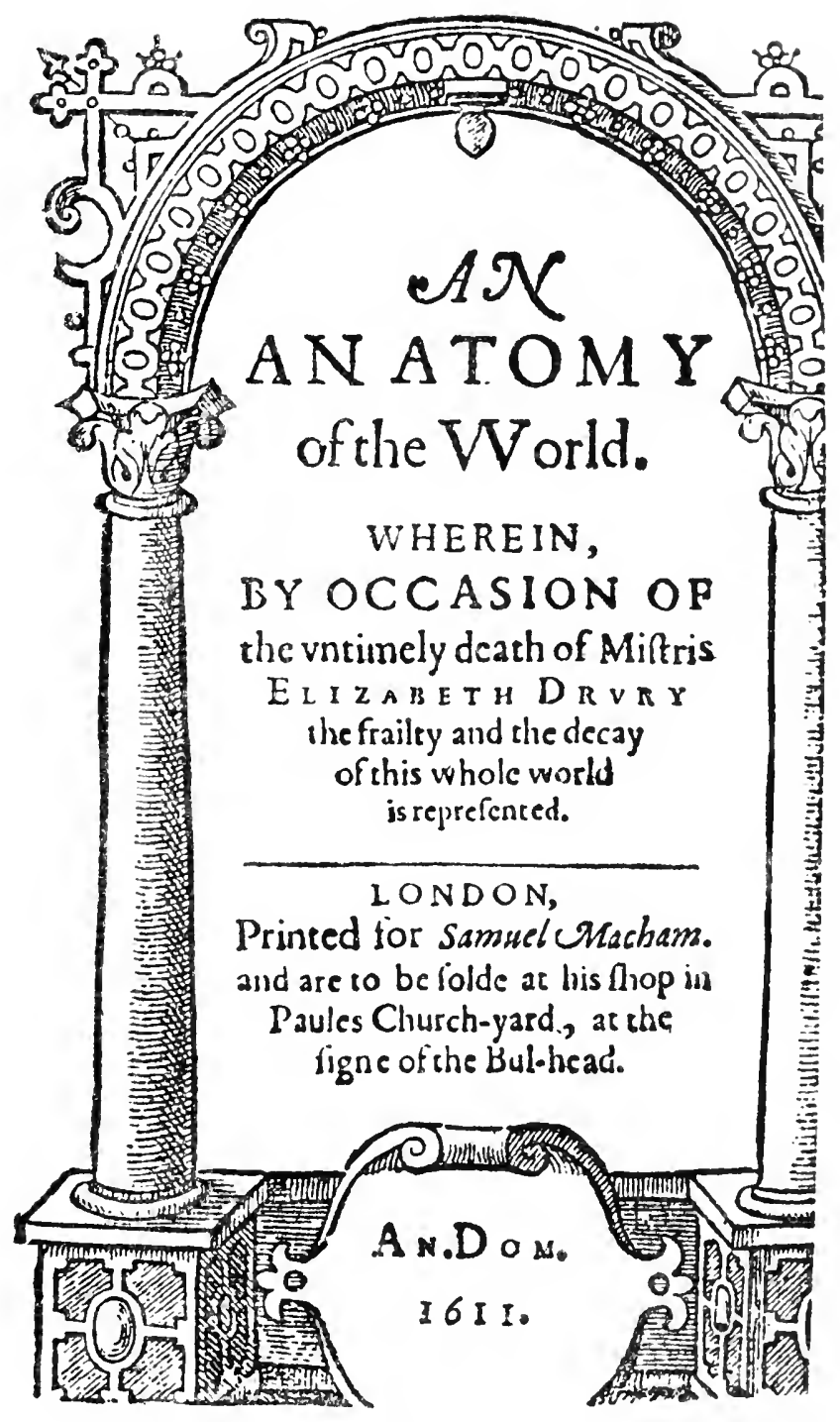

Title-page of no. 74 . 
$9^{8}$

Copies: Hoe Library (sold in New York, 26 April, 1911).

Huth Library (sold at Sotheby's, I3 June, 1912).

Library of Mr John Pearson (sold at Sotheby's, 28 January, 1914).

76 FIRST AND SECOND ANNIVERSARIES.

8o. $\mathbf{1} 62 \mathrm{I}$

First title (within double lines): The Firft Anniuerfarie. [rule] An anatomie of the World... [ornament]

London, Printed by A. Mathewes for Tho: Dewe, and are to be fold at his thop in Saint I)unftons Church-yard in Fleetettreete. I62 I.

Second title (ditto): The fecond Anniuerfarie. [rule] Of the progres of the Soule... [ormament]

London,... I 62 I.

Collation: $\mathrm{A}-\mathrm{D}^{*}, \mathrm{E}-\mathrm{H}^{8} ; 6_{4}$ leaves.

Contents: A 1 blank; A2 first title; $\mathrm{A}_{3}-\mathrm{A}_{5} a$ To the praife of the Dead, and the Anatomy; $\mathrm{A}_{5} b$ blank; $\mathrm{A}_{6}-\mathrm{D}_{3}$ (pp. $\left.\mathrm{I}-44\right)$ An anatomy of the World; $\mathrm{D}_{4}-\mathrm{D} 8$ (pp. 45-54) A funerall Elegie; EI second title; E2-E4a The barbinger to the Progreffe; $\mathrm{E}_{4} b$ blank; $\mathrm{E}_{5}-\mathrm{H}_{5} a$ (pp. $\left.\mathrm{I}-49\right)$ Of the progres of the Soule; $\mathrm{H}_{5} b-$ H8 blank.

Note: The text of this edition contains further variations.

Copies: BM, BLO (imperfect).

Edmund Gosse.

A copy was sold at Hodgson's, 25 June, 1913, and resold, 23 July, 1913.

77 FIRST AND SECOND ANNIVERSARIES.

8.. 1625

First title (within woodcut border): An anatomie of the World....The firit Anniuerfarie. [rule]

London Printed by W. Stansby for Tho. Dewe, and are to be fold in S. Dunftanes Church-yard. I 625 .

Second title (ditto): Of the progres of the foule... The fecond Anniuerfarie. [rule]

London... 1625 .

Collation: $\mathrm{A}-\mathrm{H}^{8} ; 6+$ leaves.

Contents: $\mathrm{A}_{1}-\mathrm{A}_{2}$ blank; $\mathrm{A}_{3}$ first title; $\mathrm{A}_{4}-\mathrm{A} 6 a$ To the praife of the Dead, and the Anatomy; A6b blank; $\mathrm{A}_{7}-\mathrm{D}_{4}$ (pp. I-44) An anatomie of the $W$ World; $\mathrm{D}_{5}-\mathrm{E}_{\mathbf{1}}$ 


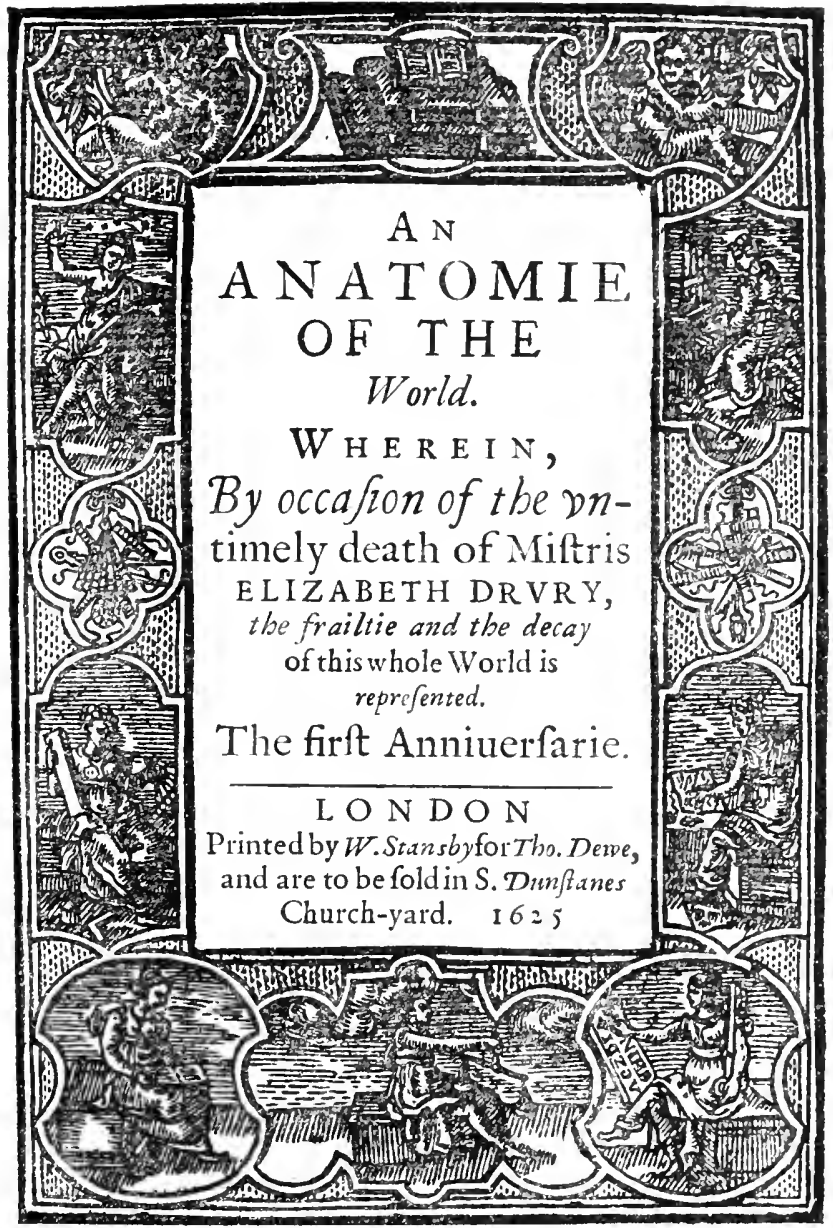

First title-page of no. 77 . 
(pp. 45-54) A funerall Elegie; $\mathrm{E}_{2}$ second title; $\mathrm{E}_{3}-\mathrm{E}_{5}$ a The harbinger to the Progreffe; $\mathrm{E}_{5} b$ blank; E6-H6a (pp. I-49) Of the progres of the Soule; H6b-H8 blank.

Note: I do not know whence the woodcut border representing the seven Liberal Arts, which surrounds the title-pages of this edition, was originally derived, but the same design occurs elsewhere; it is found, for instance, (though reversed) on the title-page of A Newe Almanacke and Prognoffication for the year of our Lord God, 1615. By Thomas Bretnor. Cum priuilegio [1615].

Copies : BM, BLO.

Hoe Library (sold in New York, 26 April, I9I1).

G. L. Keynes (imperfect). 


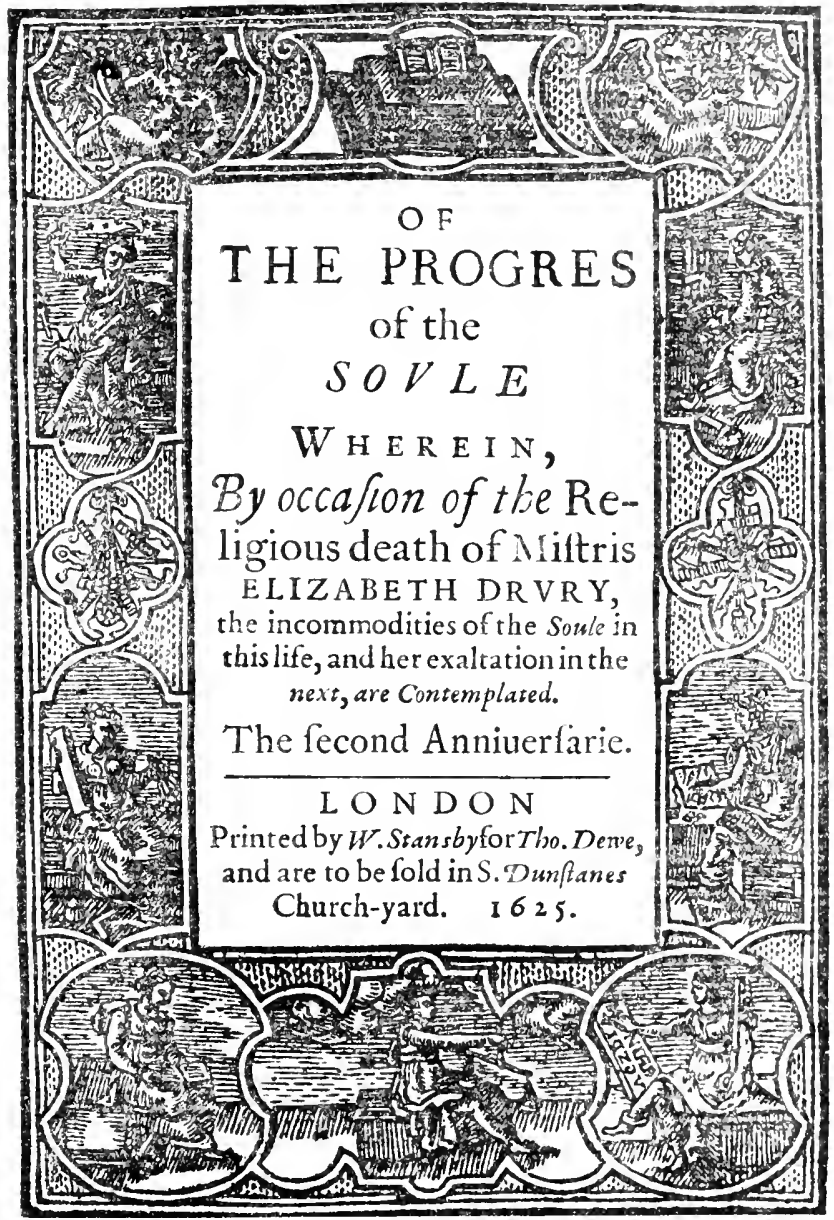

Second title-page of no. 77 . 


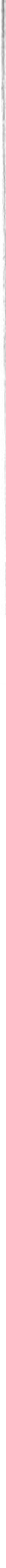


COLLECTED POEMS 


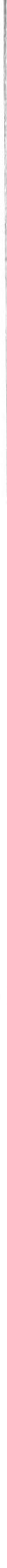




\section{COLLECTED POEMS}

\section{Bibliographical Preface}

The texts of the various editions of the collected Poems have been exhaustively dealt with in the recent Oxford edition by Professor Grierson; he gives also type-facsimiles of all the title-pages, but he only mentions some of the more strictly bibliographical details, which will be found recorded under the entries following. Very few of Donne's poems were published during his lifetime (see section on Occasional Pieces), but a large number of MS. copies were in circulation, and between twenty and thirty of these, which are all described by Grierson, ii. lxxix-cxii, have survived'. Donne died in March, I63I, and the publisher, John Marriot, seems to have entered upon the preparation of his poems for the press very shortly afterwards, helped, Grierson conjectures, by Henry King, Bishop of Chichester. The poems were registered at Stationers' Hall on September I 3,1632 , and the following entry was made :

\section{I $3^{\circ}$ Septembris 1632}

John Marriot. Entred for his Copy vnder the handes of Sir Henry Herbert and both the Wardens a booke of verses and Poems (the five satires, the first, second, Tenth, Eleventh, and Thirteenth Elegies being excepted) and these before excepted to be his when he bringes lawfull authority

written by Doctor John Dum

(Arber's Transcripts, I 877, iv. *249)

\footnotetext{
1 One of these MS. collections, designated $D$ by Grierson, ii. 1xxxiii, which was formerly' in the library of the late Edward Dowden, is now in the possession of a momber of the Baskerville Club, Mr Wilfred Merton.
}

J. D. 


\section{Bibliography of Jobn Donne}

Another entry is found shortly afterwards :

$$
3 I^{\circ} \text { octobris }\left[\mathrm{I}_{6} 3_{2}\right]
$$

John Marriott. Entred for his Copy vnder the hands of Sir Henry Herbert and Master Aspley warden The five Satires written by Doctor $\mathrm{J}$ : Dun these being excepted in his last entrance

(ibid. iv. 26I)

There is no further entry, however, concerning the excepted elegies. The first edition of the Poems, dated ${ }_{1} 6_{33}$, is, according to Grierson, the most trustworthy of the original editions, though the arrangement is somewhat chaotic. In 1635 the pieces were rearranged and a considerable number were added, but the additions contain a large proportion of spurious poems. Two more were added in $16+9$ and several unimportant pieces in I650. Several more were added in 1669, but of these only two are by Donne. In i 650 the younger Donne had secured control of the publication and the edition of that year contains a characteristic dedication from his pen. Of all the seventeenth century editions that of i 633 occurs most commonly and it contains, as has been said, the best text; the edition of r 669 is the most complete, but it contains many very bad readings and a large number of spurious pieces. Some of Donne's poems were translated into Dutch by Sir Constantine Huyghens early in the seventeenth century, though the translations were not published until 1672 (see no. 85); no other foreigner has yet repeated the attempt.

After Tonson's edition of I 7 I 9 very slight notice was taken of Donne's poems during the eighteenth century and, indeed, no edition of importance was published until they were edited by Grosart for the Fuller Worthies Library in 1872-3. The Grolier Club of New York issued an important edition in $\mathrm{I} 895$ and an exceedingly useful edition was prepared by Mr E. K. Chambers for the Muses' Library in 1896. All previous editions, however, have now been superseded by that edited in I9I 2 for the Clarendon Press by Professor H. J. C. Grierson, whose scholarship and industry have provided for readers of Donne's poems as good a text as can possibly be expected. A number of poems not previously printed were added successively by Chambers, Gosse, and Grierson. 
POEMS.

4. 1633

Title: Poems, By J. D. with elegies on the authors death. [double rule] London. Printed by M.F. for Iohn Marriot, and are to be fold at his Thop in St Dunitans Church-yard in Fleet-ftreet. 1633.

Collation: $\mathrm{A}^{4} \mathrm{~A}^{2} \mathrm{~B}-\mathrm{Z} \mathrm{Aa}-\mathrm{Zz} \mathrm{Aaa}-\mathrm{Fff}^{4} ; 210$ leaves.

Contents: A I blank; $\mathrm{A}_{2}$ title; $\mathrm{A}_{3}-\mathrm{A}_{4}$ Epiftle to The Progrefle of the Soule (Infinitati facrum, 16. Auguffi 1601. Metempfycosis); $\mathrm{A}_{1}-\mathrm{A} 2 a$ The printer to the Understanders; A2b Hexaftichon Bibliopolae signed Jo. Mar [riott]; B1-Fff (pp. 1- - 06$)$ text; Fff 4 blank.

Poems, satyres, letters, and elegies upon the author:

Poëms : I. The Progresse of the Soule, [stanzas] I-LII

PAot.

2-8. Holy Sonnets: i. La Corona

$v$. Crucifying

ii. Annunciation vi. Resurrection

iii. Nativitic vii. Ascention

iv. Temple

28

9-20. Holy Sonnets I-XII

2I-36. Epigrams: i. Hero and Leander

ix. Antiquary

ii. Pyramus and Thisbé $x$. Disinherited

iii. Niobe

xi. Phryne

iv. A burnt ship

xii. An obscure writer

v. Fall of a wall

xiii. [Klockius]

vi. A lame beggar

xiv. Raderus

vii. A selfe accuser

xv. Mercurius Gallo-Belgicus

viii. A licentious person

37. Elegie I [Iealousie. 1635]

38. Elegie II [The Anagram. 1635] +5

39. Elegie III [Change. 1635 ]

40. Elegie IV [The Perfume. 1635] 49

41. Elegie V [His Picture. 1635] 51

42. Elegie VI [Elegie on the L. C. 1635] 52

43. Elegie VII [Elegie VI. I635] 53

44. Elegie VIII [Elegie VII. I635]

45. The Storme. To Mr. Christopher Brooke 56

46. 'The Calme 59

47. To Sr Henry Wotton (Sir, more then kisses, letters mingle Soules) ú

48. The Crosse 64

49. Elegie on the Lady Marckham 66

50. Elegie on Mris Boulstred (Death I recant) 69 
Io8 Bibliography of Fobn Donne

Poems, satyres, letters, and elegies upon the author:

PAGE

51. To Sr Henry Goodyere

52. To Mr. Rowland Woodward (Like one who in her third widdowhood) 74

53. To Sr Henry Wootton (Here's no more newes) 76

54. To the Countesse of Bedford (Reason is our Soules left hand) 77

55. 'To the Countesse of Bedford (You have refin'd mee) 79

56. To Sr Edward Herbert at Iulyers 82

57. To the Countesse of Bedford (T'have written then, when you writ) 84

58. To the Countesse of Bedford. On New-yeares day (This twilight of two yeares)

59. To the Countesse of Huntingdon (Man to God's image)

6o. To M[r] I. W. [? T. W., i.e. Thomas Woodward]

90

6I. To $M[r] T$ homas] W[oodward] (Hast thee harsh verse)

93

62. To M[r] T[homas] W[oodward] (Pregnant again with th' old twins

Hope, and Feare) [last four stanzas printed separately with title Incerto in 1635]

63. To $M[r] C$ hristopher] $B[$ rooke $]$

64. To $M[r] S[a m u e l] B[$ rooke]

65. To $M[r]$ B. B. [? Basil Brooke]

66. To $M[r] R$ [owland] $W$ [oodward] (If, as mine is, thy life a slumber be)

67. To $M[r]$ I. I.

100

68. To M[r] I. P. [? should be I. L.]

IOI

69. To E[arl] of D [oncaster] with six holy Sonnets

102

70. To Sir H[enry] W[otton] at his going Ambassador to Venice ${ }^{1}$

103

7 I. To M[rs] M[agdalen] H[erbert]

72. To the Countesse of Bedford (Honour is so sublime perfection)

104

106

73. To the Countesse of Bedford. Begun in France but never perfected. (Though I be dead, and buried)

74. A Letter to the Lady Carey, and Mrs Essex Riche From Amyens

I I I

75. To the Countesse of Salisbury. August. I6I4

I 12

I I 5

76. An Epithalamion, Or mariage Song on the Lady Elizabeth, and Count Palatine being married on St. Valentine's day

77. Eclogue. I6r3. December 26.

78. Epithalamion made at Lincolnes Inne

79. To the Countesse of Bedford [letter c. 16 I4] (Gosse, ii. 43 from a MS. copy in BM)

1 Printed in Reliquiat Hottoniana. Second ed. London. $16 ;+.8^{\circ} \cdot$ p. 36 . Also in Walton's Lire', 16 ;0 etc. 
Poems, satyres, letters, and elegies upon the author:

PAGE

80. Obsequies to the Lord Harringtons brother. To the Countesse of Bedford [accompanying preceding letter]

81. Elegie (As the sweet sweat of Roses in a still) [Elegie VIII. The Comparison. 1635]

82. Elegie. The Autumnall [Elcgie IX. 1635]

83. Elegie (Image of her whom I love) [Elegie X. The Dreame. 1635] 153

84. Elegie on Prince Henry ${ }^{1} \quad 15+$

85. Psalıne 137 [stanzas] I-XI [spurious; probably by Francis Davison] 157

86. Resurrection, imperfect.

87. An hymne to the Saints, and to Marquesse Hamylton [accompanying succeeding letter]

88. [Letter to Sir Robert Ker, March, 1625$]^{2}$ (Gosse, ii. 215)

89. An Epitaph upon Shakespeare [spurious; by William Basse]

90. Sapho to Philænis

91. The Annuntiation and Passion

92. Goodfriday, 1613. Riding Westward

$164[1+8]$

93. The Litanie I-XXVIII

$165[1+9]$

166

94. (Send home my long strayed eyes to mee) [The Message. 1635]

$168[152]$

170

172

95. A nocturnall upon S. Lucies day, Being the shortest day

96. Witcheraft by a picture

97. (Come live with mee and bee my love) [The Baite. 1635]"

98. The Apparition

99. The broken heart

100. A Valediction forbidding mourning ${ }^{4}$

101. The good morrow

102. Song (Goe, and catche a falling starre) $)^{5}$

103. Womans constancy

104. (I have done one braver thing) [The undertaking. 1635]

105. The Sunne Rising

106. The Indifferent

108. The Canonization

1 First printed in Lachryma Lachrymarum, 1613 ; see no. 72.

2 Not found among the Letters of 1651 ; but reprinted from the original MS. in Epistolary Curiosities. Ist series. Ed. Rebecca Warner. Lond. 1818. $8^{\circ}$.

${ }^{3}$ Printed in Walton's Compleat Angler, Lond. 1653. $8^{\circ}$. p. 18 . See also 110. 71.

* Printed in Walton's Lives, Lond. 1675. 8\%. p. 33.

"Printed in Poems: by Francis Beaumont, Lond. 16;3. 8". on $G_{+}$. 
Poems, satyres, letters, and elegies upon the author:

PAGE

109. The triple Foole

I о. Lovers infinitenesse

I I . Song (Sweetest love, I do not goe)

112. The Legacie

I13. A Feaver

114. Aire and Angels

I 1 5. Breake of day ${ }^{1}$

116. The Anniversarie

117. A Valediction of my name, in the window. I-XI

118. Twicknam garden

119. Valediction to his booke

120. (Good wee must love) [Community. I635]

121. Loves growth

122. Loves exchange

123. (Some man unworthy to be possessor) [Confined love. 1635]

124. The Dreame

125. A Valediction of weeping

126. Loves Alchymie

127. The Flea

i28. The Curse

129. An Anatomie of the World. The first Anniversary

130. The progresse of the soule. The second Anniversary

I3I. The Extasie

132. Loves Deitie

133. Loves diet

134. The Will

135. The Funerall

136. The Blossome

137. The Primrose

I38. The Relique

I39. The Dampe

140. The Dissolution

141. A Ieat Ring sent

142. Negative love

143. The Prohibition

144. The Expiration

145. The Computation
204

205

206

208

209

2 I I

212

213

214

218

219

222

223

224

226

227

228

229

230

231

233

257

277

280

281

283

285

286

288

289

290

291

292

293

294

295

295

${ }^{1}$ Set to music in Corkine's Booke of Ayres. See no. 71. 
Poems, satyres, letters, and elegies upon the author:

PAGE

146. Elegie (Language thou art too narrow) [Elegie XI. Death. 1635] 296

147. Elegie to the Lady Bedford (You that are she)

298

148. Elegie (To make the doubt cleare) [Elegie XVII. The Expostulation. $\left.{ }^{16} 6\right]^{1}$

149. (No Lover saith, I love) [The paradox. I635]

150. A Hymne to Christ, at the Authors last going into Germany

300

302

304

151. The Lamentations of Ieremy, for the most part according to Tremelius.

Chap. I-V

Satyres: 152-156. Satyre I-V

Poëms : 157. A Hymne to God the Father [stanzas] I-III²

Letters: 158. [To] Hen. Goodeere [in Latin] (Alford, vi. 440)

I 59. To Sir H[enry] G[oodyer] [1609] (Letters, I65I, no. 36; Gosse, i. 227)

I60. Ditto [1607] (Letters, I651, no. 33; Gosse, i. 177)

351

16I. Ditto [1607] (Letters, I65 I, no. 30 ; Gosse, i. I69)

162. Ditto [Aug. I 5, I607] (Letters, I651, no. 38 ; Gosse, i. I68)

I63. Ditto [1609] (Letters, I65I, no. 21 ; Gosse, i. 218)

362

I64. To the Countesse of Bedford [1609] (Letters, I65I, no. 23; Gosse, i. $2(7)$

I65. To Sr H[enry] G[oodyer] [1608] (Letters, 165 I, no. 27; Gosse, i. I 85)

I66. Ditto [1608] (Letters, I65I, no. 25; Gosse, i. I83)

Elegies upon the Author: 167 . To the memorie of my ever desired friend Dr. Donne [by] H[enry] K[ing $]^{3}$

I68. To the deceased Author, Upon the Promiscuous printing of his Poems, the Looser sort, with the Religious [by] Tho: Browne*

169. On the death of Dr. Donne [by] Edw. Hyde ${ }^{5}$

I 70. On Doctor Donne By Dr C[orbet] B[ishop] of O[xford] ${ }^{6} \quad 378$

I 7r. An Elegie upon the incomparable Dr. Donne [by] Hen. Valentine 38 r

1 Printed among Underwoods in Ben Jonson's Works, Lond. 16 fo. Fo. p. 20 .

2 Printed in Walton's Life, 1640 etc.

${ }^{3}$ Also in Death's Duell, 1632 ; Walton's Life, 1658 ctc.; King's Pocms, 1657 etc.

4 This Elegy is omitted from later editions of the poems. Its author is identified by Mr Gosse with Sir 'Thomas Browne of Norwich (Life of Sir T. B. By E. Gosse. Lond. 1905. 80. p. 18), and Grierson (ii. 255) accepts this identification, though there is no evidence in support of it. It seems to me most improbable that the elegy is by Sir 'Thomas Browne. Possibly it is by the signatory of the Imprimatur of the 80 Sermons, 1640 (see no. 29).

5 Also in Death's Duell, 1632.

"Also in Walton's Life, 1658 etc.; Corbet's Poems, $16+7$. 
Poems, satyres, letters, and clegies upon the author:

172. An Elegie upon Dr. Donne [by] Iz[aak] Wa[lton] ${ }^{1}$

173. An Elegie upon the death of the Deane of Pauls, Dr. Iohn Donne:

By Mr. Tho: Carie'2

174. An Elegie on Dr. Donne: By Sir Lucius Carie

175. On Dr. Donnes death: By Mr. Mayne of Christ-Church in Oxford $3^{89}$

176. Upon Mr. J. Donne, and his Poems [by] Arth. Wilson

177. In memory of Doctor Donne: By Mr. R. B.

178. Epitaph [anon.]

I79. Epitaph upon Dr. Donne, By Endy: Porter

Note: This book appears to have been repeatedly corrected as it passed through the press and consequently it is found in a number of different states. I have not collated in detail the texts of the numerous copies that have been in my hands, but I have applied to most of them a rough test which has served to some extent to differentiate them. This test depends on the three following points :

i. The signature on the first leaf of The printer to the Understanders is in the earliest copies *, but it was afterwards altered to $A$.

ii. Page 8, line 7 , has in earlier copies "to fee the Prince," but this was altered later to " to fee the Princeffe."

iii. Page 326, third line from bottom, has in earlier copies "Charitably warm'd of thy finnes," and in later copies "Charitably warn'd of thy finnes."

Thus one finds copies on the one hand with sign. *, "to fee the Prince," and "Charitably warm'd"; this is the earliest form of all. On the other hand the majority of copies have sign. A, "to fee the Princefle," and "Charitably warn'd." There occur also every possible combination of these three misprints, indicating intermediate states. The pagination, which is faulty, varies in different copies; the mistakes, which occur in a copy of the final form of the book as determined by the above test, are noted in square brackets in the page references of the list of contents given above.

The first quire of the book consists of four leaves : first leaf blank, second leaf title, third and fourth leaves (with sign. $\mathrm{A}_{3}$ and $\mathrm{A}_{4}$ ) the Epifle etc. The two leaves with The printer to the Understanders and Hexastichon Bibliopolae (with sign. $\mathrm{A}$ and $\mathrm{A} 2$ ) are an insertion, and are placed sometimes after the Epifle, but more often in the centre of the first quire, so that the collation then appears to be: [a] I blank, [a]2 title, $\mathrm{A}_{1}-\mathrm{A}_{2}$ The printer etc., $\mathrm{A}_{3}-\mathrm{A}_{4}$ Epiftle etc., and this has misled

1 Also in Walton's Lives, 1670 etc.

- Also in Carew's Poems, 1640. 
some authorities. The correct collation is printed above. Sometimes the two leaves of $T$ be printer etc. are omitted altogether.

This edition of the Poems properly contains no portrait, but the engraving by Lombart is found inserted in some copies, or, very rarely, the engraving by Marshall printed on paper of quarto size'.

This edition and those issued up to I649 were printed by Miles Fletcher ( I6I I-I664).

Copies : BM, ULC (imperfect), BLO (2).

Cambridge Colleges: Christ's, Clare (the earliest state), Corpus Christi, Gonville and Caius, St John's, 'Trinity (2).

Oxford Colleges : All Souls, Christ Church, Corpus Christi, St John's.

Lincoln Cathedral Library.

John Rylands Library, Manchester.

Edmund Gosse; G. L. Keynes (imperfect).

POEMS.

$8 \circ .1635$

Title: Poems, By J. D. with elegies on the authors death. [double rule] London Printed by M. F. for John Marriot, and are to be fold at his Shop in $\mathrm{S}^{\mathrm{t}}$ Dunftans Church-yard in Fleet-ftreet. $\quad$ I635.

Collation: $A-Z$ Aa-Dd ${ }^{8} ; 216$ leaves.

Contents: A I title; $\mathrm{A}_{2}-\mathrm{A}_{4} a$ The printer to the understanders; $\mathrm{A}_{4} b$ Hexajticbon Bibliopolae and Hexaftichon ad Bibliopolam. Incerti.; A $5-\mathrm{A} 6$ a Epiftle to The Progrelle of the Soule; A6b blank; A7-Bb8 (pp. I-388) text; CcI-Dd8a Elegies upon the Autbor (errata at bottom of $\mathrm{Dd} 8 a)$; Dd8b blank.

Frontispiece: Inserted before AI. A portrait of Donne at the age of $\mathrm{I} 8$, engraved by Marshall; the painting from which the engraving was done is not known². A bust of the subject is shewn, within an oval, $8.5 \times 6 \mathrm{~cm}$. His dress is plain, but he is represented with long hair and with a large ear-ring in the shape of a cross hanging from his right ear. His right hand is grasping the hilt of his sword. Above the oval, on the left, the engraving is inscribed: Anno Dni. I591. | attatis suae. I 8.; above, on the right, is a crest with motto: Antes muerto que mudado". Below are eight lines of verse, beginning: This was for youth, Stringth, Mirth, and wit, and signed $I z: I V a:[I z a a k W$ alton]. At the bottom, on the left, the engraving is signed: Will: Marshall. foulpsit. The plate-mark measures $12.3 \times 7.7 \mathrm{~cm}$.

I A copy is recorded by Lowndes.

2 $\mathrm{Mr}$ Lawrence Binyon has suggested that it may have been by Nicholas Ililliasd, 1537-1619 (Grierson, ii. 134).

i.e. Sooner death than change.

J. D. 
Poems, etc.: As in the edition of 1633 with the omission of nos. 87 and 166 , and with the addition of the following:

Poems : I. Song (Soule's joy now I am gone) [spurious; probably by the Earl of Pembroke]

PAGE

2. Farewell to Love

3. Song (Deare Love continue nice and chaste) [spurious; by Sir John Roe]

4. Song (Stand still and I will read to thee) [A Lecture upon the Shadow. I650]

5. Elegie XII. The Bracelet

6. Elegie XIII. (Come, Fates ; I feare you not) [spurious; probably by Sir John Roe]

7. Elegie XIIII. His parting from her

8. Elegie XV. Julia

9. Elegie XVI. A tale of a Citizen and his IVife

Satyres: Io. Satyre VI [Satyre VII, 1669] [spurious; probably by Sir John Roe]

Poems: II. To the Countess of Huntingdon (That unripe side of earth) [spurious; probably by Sir John Roe]

12. A Dialogue between Sr Henry Wotton and Mr. Donne [spurious; by Pembroke and Ruddier]

13. To Ben Iohnson, 6 Ian. I603 [spurious; by Sir John Roe]

14. To Ben Ionson, 9 Novembris. I603 [ditto]

I 5. To Sir Tho. Roe. I603 [ditto]

17. Elegie (That I might make your Cabinet my tombe) [repeated in no. 33

On himself]

I8. Elegie on Mistris Boulstred (Death, be not proud) [spurious; probably by Sir John Roe]

Letters : I 9. Doctissimo Amicissimoque v. D. D. Andrews

20. To the La[dy] G[rymes ?] Amyens, Feb. 7, i6 I I (Letters, I65 I, no. 88; Gosse, i. 289)

21. To My honour'd friend G[eorge] G[errard] Esquier, Paris, April I4, I6I 2 (Letters, 1651 , no. 85 ; Gosse, i. 303)

22. Ditto. Aberyhatch, Nov. 2, 1630 (Letters, I65I, no. 86 ; Gosse, ii. 266)

23. Ditto. Jan. 7, I630 (80 Sermons, I640; Letters, I651, no. 87 ; Gosse, ii. 268)

Divine Poems : 24-27. Holy Sonnets XIII-XVI 
PAC;E

28. On the blessed Virgin Mary [spurious; probably by Henry Constable]

342

29. Upon the translation of the psalms by Sir Philip Sidney and the Countesse of Pembroke his Sister

30. Ode

31. To Mr Tilman after he had taken orders

32. On the Sacrament [spurious; ascribed to Queen Elizabeth]

33. On himselfe

34. Hymn to God my God in my Sicknesse ${ }^{1}$

Elegies on the Author:

35. In obitum venerabilis viri Iohannis Dome [by] Daniel Darnelly. Cc2

36. Elegie on D. D. [by] Sidney Godolphin.

37. On Dr. John Donne, late Deane of S. Paules, London [by] I. Chudleigh ${ }^{2}$.

Note: In this edition the pieces have been rearranged (see Grierson, ii. lxiii) and there are some changes in the text; they include all that had appeared in 1633 with the exception of Basse's Epitaph upon Shakespeare, and Thomas Browne's elegy on the author. Of the thirty-seven pieces that have been added twenty-nine are poens supposed to be by Donne; of these one (no. 17) appears twice and eleven are not accepted by Grierson as genuine. This edition contains therefore seventeen additional poems by Donne. The Hexasticbon ad Bibliopolam. Incerti on $\mathrm{A}_{4} b$ is also an addition.

The errata, signed Thine, $I[\mathrm{obn}] M$ [arriot], explain that the Epiflle to The Progrelfe of the Soule (on $\mathrm{A}_{5}-\mathrm{A} 6$ ) should have been printed before the poem at p. 30I. There seems, however, to have been an earlier issue in which the errata do not appear. This fact was communicated to me by Miss Henrietta C. Bartlett of New York, who had herself examined an example of this issue in the library of Mr Beverley Chew; she states that the volume, which, as far as I kuow, is unique, is in other respects identical with the ordinary issue.

Copies: BM, ULC, BLO.

Cambridge Colleges: Christ's, Magdalene (2, no portraits).

POEMS.

8०. 1639

Title: Poems, By J. D. with elegies on the authors death. [ornament between rules]

1 Printed in Walton's Liz'es, London, 1670 etc. 8". p. 60.

2 Part is printed in Walton's Life, $16 ; 8$ etc. 


\section{I 6

London, Printed by M. F. for John Marriot, and are to be fold at his Shop in $\mathrm{S}^{t}$ Dunftans Church-yard in Fleet-ftreet. I 639.

Collation: $\mathrm{A}-\mathrm{Z} \mathrm{Aa}-\mathrm{Dd}^{3} ; 2 \mathrm{I} 6$ leaves.

Contents: A I title; $\mathrm{A}_{2}-\mathrm{A}_{4} a$ The printer to the understanders; $\mathrm{A}_{4} 6$ Hexaftichon etc.; $A_{5}-V_{2}$ (pp. I-300) text ; $V_{3}-V_{4}$ Epiftle to The Progrefle of the Soule; V 5-Bb8 (pp. 30I-388) text; CcI-Dd8a Elegies upon the author; Dd86 blank. Frontispiece, Poems, etc.: As in the edition of 1635 .

Note: The errata have been corrected and the Epijtle to The Progreffe of the Soule has been printed in its proper place between pp. 300 and $30 \mathrm{I}$. There are a number of minor changes in the text.

Copies: BM, BLO.

Cambridge Colleges: St John's, Trinity.

Christ Church, Oxford.

Canterbury Cathedral Library.

Edmund Gosse (imperfect).

8 I POEMS.

8.. $\quad 1649$

Title: Poems, By J. D. with elegies on the authors death. [ornament between rules]

London Printed by M.F. for John Marriot, and are to be fold at his thop in $\mathrm{S}^{t}$ Dunftans Church-yard in Fleet-ftreet. $\quad 1649$.

Collation: $\mathrm{A}^{4} \mathrm{~B}-\mathrm{Z} \mathrm{Aa}-\mathrm{Cc}^{8} ; 204$ leaves.

Contents: A I blank; $\mathrm{A}_{2}$ title; $\mathrm{A}_{3}-\mathrm{A}_{4} a$ The printer to the understanders; $\mathrm{A}_{4} b$ Hexaftichon etc.; $\mathrm{BI}-\mathrm{Aa} 8$ (pp. I-368) text ; $\mathrm{BbI}-\mathrm{Cc} 8 a$ Elegies upon the Author; Cc8b blank.

Frontispiece: As in the edition of 1635 .

Poems, eti.: As in the edition of 1635 with the addition of the following, after the Funerall Elegies, pp. 262-265:

I. Upon Mr 'Thomas Coryat's Crudities'.

2. Sonnet. The Token.

Note: Of this edition very few copies seem to have been circulated, and it is now extremely rare. Probably it was never actually published, the sheets of most of the copies being incorporated in the volume issued by the same publisher in 1650 under

1 First printed in Coryat's Crudities, 1611 ; see no. 70. 
the editorship of the younger Donne (see next entry). It contains a few unimportant changes in the text.

Copies : Library of Harvard University (examined for Prof. Grierson by Miss Mary H. Buckingham).

Library of Beverley Chew, Esq., New York (examined for me by Miss Henrietta C. Bartlett).

G. L. Keynes.

POEMS.

8०. 1650

Title: Poems, By J. D. with elegies on the authors death. To which Is added divers Copies under his own hand never before in print. [rule] London, Printed for John Marriot, and are to be fold by Richard Marriot at his fhop by Chancery lane end over againt the Inner Temple gate. I650.

Collation: $\mathrm{A}^{4} \mathrm{~B}-\mathrm{Z} \mathrm{Aa}{ }^{8} \mathrm{aa}^{8} \mathrm{bb}^{4} \mathrm{Bb}-\mathrm{Cc}^{8} ; 2 \mathrm{1} 6$ leaves.

Contents: A I blank; A2 title; $\mathrm{A}_{3}-\mathrm{A}_{4}$ a To the Right Honsurable IVilliam Lord Craven Baron of Hampled-Marfham signed Fobn Donne [jun.]; A4b Hexaftichon Bibliopolae, Hexaftichon ad Bibliopolam. Incerti, and To 'Jobn Donne by B[en] Fons [on]; $\mathrm{BI}_{-} \mathrm{bb}_{4}$ (pp. 1-392) text; $\mathrm{BbI}-\mathrm{Cc} 8 a$ Elegies upon the Author; Cc8b blank.

Frontispiece: As in the edition of 1635 .

Poems, etc.: As in the edition of 1649 , with the addition of the following on the extra leaves, aa I-bb4 (pp. 369-392):

I. Newes from the very Countrey

2. Amiciffimo, \& meritiffimo Ben. Jonson. In Vulponem²

3. Aevum fortiti fumus...

4. Catalogus Librorum

5. In Sacram Anchoram Pifcatoris [by] G. Herbert ${ }^{3}$

6. To Mr George Herbert, with one of my Seal, of the Anchor and Christ

7. A fheafe of Snakes ufed heretofore to be my Seal, the Creft of our poore Family ${ }^{4}$

8. Ut primum per literas...

9. Tranflated out of Gazæus, Vota Amico facta. fol. 160.

1 First printed in Overburie's Characters, 1615 ; see no. 73.

2 First printed in Ben Jonson's Volpone, 1607 ; see no. 69.

3 Printed in Walton's Life, 1658, p. 84 . Ibid. p. 83. 
10. To Lucy, Countefle Of Bedford, with M. Donnes Satyres [by] Ben. Jon[son] 11. To John Donne [by] Ben. Jon[son]

12. [No title] (The heavens rejoyce in motion; why should I) [Elegy XVII. Variety. 1669]

13. [No title] (He that cannot chufe but love) [Self-love. Chambers]

Note: The sheets $\mathrm{B}-\mathrm{Aa}$ and $\mathrm{Bb}-\mathrm{Cc}$ were probably those of the preceding entry or at least were printed from the same type, but the first quire of four leaves was changed; in addition to the alterations on the title-page the younger Donne's dedication to Lord Craven was substituted for The printer to the understanders, and a third poem, by Ben Jonson, was added on $\mathrm{A}_{4} b$. Furthermore, the additional sheets $\mathrm{aa}, \mathrm{bb}$ were inserted after $\mathrm{Aa} 8$, or, sometimes, in error, after $\mathrm{Cc}_{\mathrm{c}} 8$, so that this volume is very variously composed.

Copies: BM.

Emmanuel College, Cambridge (sheets $\mathrm{A}$, aa, and bb only).

Christ Church, Oxford.

Canterbury Cathedral Library.

G. L. Keynes.

83 POEMS.

8. 1654

Title: Poems, By J. D. with elegies on the authors death. To which Is added divers Copies under his own hand never before in Print. [rule] London, Printed by J. Flether, and are to be fold by John Sweeting, at the Angel in Popeshead-Alley. I 654.

Collation, Contents, Frontispiece, Poems, etc.: As in the edition of 1650 .

Note: A reissue of the last edition with cancel title-page.

Copies: BM, BLO.

Cambridge Colleges: Gonville and Caius, Jesus (no portrait), Pembroke, St John's. Christ Church, Oxford.

Edmund Gosse (no portrait); G. L. Keynes.

84 POEMS.

8. $\quad 1669$

Title: Poems, \&c. by John Donne, late Dean of St. Pauls. With elegies on the authors death. To which is added Divers Copies under his own hand, Never before Printed. [double rule]

In the Savoy, Printed by T. N. for Henry Herringman, at the fign of the Anchor, in the lower-walk of the New-Exchange. I 669.

Collation: $\mathrm{A}^{4} \mathrm{~B}-\mathrm{Z} \mathrm{Aa}-\mathrm{Dd}^{8} ; 2 \mathrm{I} 2$ leaves. 
Contents: A I blank; A2 title; $\mathrm{A}_{3}-\mathrm{A}_{4} a$ dedication to Lord Craven; $\mathrm{A}_{4} b$ Hexaftichon etc. ; BI-Dd7 (pp. I-4I4) text ; Dd8 blank.

Poems, etc. : As in the edition of 1650 with the addition of the following:

1. Break of day, stanza 1 [spurious; probably by John Dowland]

PAGE

2. Elegie XIIII, 11. 5-44, 57-66, and 83-94

3. Elegie XVIII [Love's Progrels. MS.]'

4. To his Miftrels going to bed [Elegy XIX. Going to bed. MS.]

5. Satyre VI (To Sir Nicholas Smyth) [spurious; probably by Sir John Roe] I 38

Note: Printed by Thomas Newcomb (1649-168I). There are numerous changes in the text of this edition. Hazlitt states that pp. 95-98, containing the additional elegies, were suppressed, but I have not yet seen a copy in which this was the case. This edition does not, as is sometimes stated ${ }^{2}$, contain a portrait. Pp. I 2 I, I23, 22 I are numbered $22 \mathrm{I}, 2 \mathrm{I} 3,29 \mathrm{I}$, but with these exceptions the pagination is correct up to p. 304 (U8b); it then becomes very erratic, and the remaining quires are numbered as follows: sign. $X$ is paginated $307-322$; sign. $Y, 321-336$; sign. $\%$, $377-392$; and sign. Aa-Dd, 353-414.

Copies: BM.

Cambridge Colleges : King's, St John's, Trinity.

Oxford Colleges: All Souls, Christ Church, Merton.

Cosmo Gordon; Edmund Gosse; G. L. Keynes (2).

HUYGHENS'S KORENBLOEMEN.

$4^{\circ} \cdot \quad 1672$

Title: Koren-bloemen. Nederlandfche gedichten Van Constantin Huygens

Ridder,...Tweede druck...t'Amstelredam,... 672.

Translations: Pt. Ir. pp. 533-537 Uyt Engelfch Dicht Van Doctor John Donne

1. De Vloy [1633, no. 127$]$

2. De verfchijningh [1633, no. 98]

3. Toovery door een' Schildery [1633, no. 96]

4. Den Hof te Twichnam [1633, no. I I 8 ]

5. Liedt $[1633$, no. 102]

6. De dry-dobbele geck [1633, no. 109]

7. Schreyens aficheit $[1633$, no. 125]

8. De Droom [1633, no. 124]

9. De Verftellingh $\left[16_{33}\right.$, no. $\left.3^{8}\right]$

1 Printed in Wit and Drollery, London, 1661. 8. p. 237.

2 This mistake appears to hate been originated by Lowndes. 
Io. Aen fijn Lief [1633, part of no. 43]

II. De Vervoeringh [1633, no. I3I]

I 2. De Bloeflem [1633, no. 1 36]

I3. V rouwen ttandvaftigheit [ 1633 , no. I03]

I4. Affcheit, met verbod van treuren [1633, no. Ioo]

15. De opgaende Son [1633, no. 105]

16. Dageraet [ 1633 , no. I 15$]$

I7. Godheit de Minne [1633, no. I 32]

I 8. De Dood-gift [ [633, no. I I 2]

I9. Goede Vrydagh. Rijdende Weftwaert [1633, no. 92]

Note: The translations are preceded by one leaf Tot den leser, and two poems, Aen Tefelfchade and Aen ein' fchoone Weduwer. Huyghens explains in the note Tot den leser that "Charles I having heard of his intention to translate Dr Donne, 'declared he did not believe that anyone could acquit himself of that task with credit" (Grierson, ii. Ixxvii). This is also referred to by Morhof in his Polybistor (see no. I09) where he writes: "Quorum [Pocmata] aliquot in Linguam Belgicam vertit Constantius Hugonius a Carolo secundo Rege sollicitatus, qui inimitabilem Germanis et Belgis hujus viri stylum putabat." For Huyghens's opinion of Donne expressed in a letter to Hooft in 1630 see Grierson (loc. cit.). The translations are also referred to in M. Llewellyn's Men-Miracles, 1646 , in a passage the last two lines of which run :

Thus we climbe downwards, and advance as much As He that turn'd Donne's Poems into Dutch.

(J. B. to my Ingenious Friend Captaine LL.)

86 POEMS. I $2^{\circ}: 1719$

Title: Poems on feveral occafions. Written by the Reverend John Donne, D.D. Late Dean of St. Paul's. With Elegies on the Author's Death. To this Edition is added, Some Account of the Life of the Author. [double rule]

London: Printed for J. Tonfon, and Sold by W. Taylor at the Ship in Pater-nofter-Row. 1719.

Collation: $\mathrm{A}-\mathrm{Q}^{12} \mathrm{R} \mathrm{S}^{2} ; \mathrm{I} 96$ leaves.

Contents: A 1 title; $\mathrm{A}_{2}-\mathrm{A}_{3}$ dedication to Lord Craven; $\mathrm{A}_{4}-\mathrm{A}_{9}$ a Some account $O f$ the life of Dr. Fohn Donne; Agb Hexaftichon etc.; A Io-A I 2 contents; BI-Sia (pp. I-365) text; $\mathrm{S}_{1} b-\mathrm{S}_{2}$ Books Printed for Facob Tonfon.

Poems, etc. : As in the edition of 1669 with the omission of Satyre VI (addition no. 5, I669). 
Note: 'The account of Donne's life is abridged from Walton.

Copies: BM, ULC.

Trinity College, Cambridge.

Cosmo Gordon; G. L. Keynes; C. Sayle.

87 POPE'S WORKS.

8.. 1735

The Works of Alexander Pope, Efq.; vol. I1...London : Printed for L. Gulliver, I735. $8^{\circ}$.

Poems : pp. 131-16I. Satires of Dr. John Donne [the second and fourth, vervified by $A$. Pope, with the original versions on the left-hand pages].

88 POEMS.

12. $\quad 1779$

The Poetical Works of Dr. John Donne,...In three volumes. With the life of the author...Edinburg: at the Apollo Prefs, by the Martins. Anno I 779. [Bell's Edition of the Poets of Great Britain, Vols. 23-25.] I $2^{\circ}$. Vol. I. pp. cvi + I09-I65. Vol. II. pp. i68. Vol. 11. pp. 192.

Frontispiece : to vol. 1. Portrait of Donne engraved by Cook (after the engraving by Lombart).

89. POEMS ED. ANDERSON.

8. 1793

A Complete Edition of the Poets of Great Britain. Volume the Fourth London :... and...Edinburgh. [I793] [Ed. by R. Anderson] $8^{\circ}$.

Pp. I-ro7. The Poetical Works of Dr. John Donne, with short life.

90 TWO POEMS ED. WALDRON.

$4^{\circ} \cdot 1802$

The Shakspearean miscellany :...Printed chiefly from Manuscripts...by'

F. G. Waldron,...London :... I $802.44^{\circ}$.

Poems: Among Miscellaneous Poetry.

Pp. I-5. Two Elegies by Dr. Donne

I. (Till I have peace with thee warre other men) [Love's War]

2. (Is death so great a gamester that he throws)

Note: The first is also printed by Waldron in his Collection of Miscellanrous Poctry, I802, and, later, by Simeon (see no. 97). The second is by William Browne. J. D. 
9 I POEMS ED. CHALMERS. 8o. 1810

The works of the English poets,...including the series edited,...by Dr. Samuel Johnson :...The additional lives by Alexander Chalmers, F.S.A. In twenty-one volumes. Vol. v....London :... 8 10. $8^{\circ}$.

Pp. 116-218. Poems of John Donne, with life by Chalmers.

92 SELECTED POEMS ED. CAMPBELL. 8०. 1819 Specimens of the British Poets; with biographical and critical notices,... By Thomas Campbell. In seven volumes. Vol. ir....London: John Murray,... I 8 I $9 . \quad 8^{\circ}$.

Pp. 73-79. Four poems by Donne, with biographical notice.

93 SELECTED POEMS ED. SANFORD. I $2^{\circ} . \quad \times 8 x 9$

The work of the British poets. With lives of the authors, by Ezekiel Sanford. Vol. Iv....Philadelphia:... I 8 I 9. I $2^{\circ}$.

Pp. 133-195. Select Poems of Donne, with life by Sanford.

94 POEMS ED. SOUTHEY.

8o. 1831

Select works of the British poets,... with biographical sketches by Robert Southey Esqr. Ll.D. London... I 83 I. $8^{\circ}$.

Pp. 714-731. Poems of John Donne, with life by Southey.

95 SELECTIONS. I $2^{\circ} . \quad 1840$

Selections from the Works of John Donne, D.D.... Oxford: D. A. Talboys. I $840 . \quad$ I $2^{\circ}$. pp. vi (numbered viii) +280 .

Note: This consists chiefly of prose extracts, with a selection from the poems at the end.

96 POEMS.

8o. $\quad 1855$

The Poetical Works of Dr. John Donne, with a memoir. Boston : Little, Brown and Company... m.Dccc.lv. $8^{\circ}$. pp. xxii $+43 \mathrm{I}$.

Frontispiece: Portrait of Donne, drawn and engraved by S. A. Schoff (after the engraving by Merian). 
UNPUBLISHED POEMS ED. SIMEON.

Miscellanies of the Philobiblon Society. Vol. 111... London :...1856-7.

Poems: Unpublished Poems of Donne, $3^{1} \mathrm{pp}$., with a prefatory note by Sir John Simeon, Bart.

Note: Simeon prints here seventeen poems and three epigrams, all of which are spurious or doubtful except one ('Till I have peace with thee, war other men), which had already been printed by Waldron (see no. 90).

POEMS ED. GROSART.

8. $\quad 18-2$

The Fuller Worthies Library. The complete poems of John Donne, I.1). Dean of St. Pauls. For the first time fully collated with the original and early editions and MSS. and enlarged with hitherto unprinted and inedited poems from MSS. etc. and portraits, facsimiles, and other illustrations in the quarto form. Edited with preface, essay on life and writings, and notes, by the Rev. Alexander B. Grosart,... In two volumes. Vol. I. [II.] Printed for private circulation. I $872.8^{\circ}$. Vol. 1. pp. $x i v+278+[2]$. Vol. Ir. pp. $[i i]+1 v i+358$.

Illustrations: I. Vol. I. Frontispiece. A bust of Donne in an oval $5.5^{\circ} \times 4.2 \mathrm{~cm}$, "Engraved by W. J. Alais from a miniature painted in 1610 by Isaac Oliver, in the possession of Mr. Samuel Addington."

-2. Vol. II. Frontispiece. A reproduction of the engraving by Marshall.

3. Vol. II. Facing p. ix. Reproductions of Droeshout's engraving, of Hollar's engraving of the effigy in St Paul's, and of Donne's autograph and seals.

Note: A number of poems were printed here for the first time from MSS., but none of them are accepted by Grierson as genuine. 100 copies were printed on large paper $\left(4^{\circ}\right)$.

POEMS ED. LOWELL.

8․ $\quad 1895$

The Poems of John Donne from the text of the edition of 1633 revised by James Russell Lowell with the various readings of the other editions of the seventeenth century, and with a preface, an introduction, and notes by Charles Eliot Norton. Volume 1. [11.] New York: The Grolier Club, I 895. 8. Vol. I. pp. xxxviii $+[i i]+253+[5]$. V'ol. 11. pp. $x+[i i]+282+[8]$. 
Frontispices: Portraits of Donne etched by S. J. Ferris (after the engravings by Marshall and Lombart).

Note: 380 copies on hand-made paper, and 3 on vellum.

IOO POEMS ED. CHAMBERS.

8.. 1896

The Poems of John Donne. Edited by E. K. Chambers. With an Introduction by George Saintsbury. Vol. I. [11.] London: Lawrence EF Bullen... I 896. [The Muses' Library] 8\%. Vol. I. pp. [ii] $+\mathrm{lii}+25^{\circ}$. Vol. Ir. pp. $x i+326+[2]$.

Note: 100 copies were printed on large paper and contain a photogravure frontispiece after the portrait of Donne ascribed to Cornclius Janssen.

IOI POEMS ED. CHAMBERS.

8o. n. d.

The Muses' Library. Poems of John Donne. Edited by E. K. Chambers. With an Introduction by George Saintsbury. Vol. I. [II.] London: George Routledge $E$ Sons, Limited. New York: E. P. Dutton E Co. [n. d.] $8^{\circ}$. Vol. 1. pp. lii +252 . Vol. II. pp. ix +326 .

IO2 SELECTED POEMS.

8o. 1904

The Orinda Booklets V. John Domne: Selected Poems. Henry King : Elegies, etc. Izaak Walton : Verse-Remains. J. R. Tutin, Cottingham near Hull. I904. Limited to I000 copies. $8^{\circ}$. pp. $63+[\mathrm{I}]$.

IO3 LOVE POEMS ED. NORTON.

$12^{\circ} .1905$

The Love Poems of John Donne selected and edited by Charles Eliot

Norton. Boston: Houghton, Mifflin \& Company. MDccccv. I $2^{\circ}$. pp. $\mathrm{xii}+[\mathrm{ii}]+85+[\mathrm{I}]$.

Note : 535 copies printed at the Riverside Press, Cambridge, Mass.

IO4 SELECTED POEMS.

$4^{\circ} .1905$

Poems of John Donne selected from his songs, sonnets, elegies, letters, satires, and divine poems...The Marion Press, Jamaica, Queensborough, New-York. I905. $4^{\circ}$. pp. xiii $+[i i i]+$ I $33+[3]$.

Frontispicce: Portrait of Donne engraved on wood by Henry Wolf (after the painting in the Deanery of St Paul's).

Note: 100 copies printed on hand-made paper. There is a short introduction by Mr Frank L. Babbott, for whom the volume was printed. 


\section{Collected Poems $\quad$ I 25}

5 POEMS ED. GRIERSON.

89. 1912

The Poems of John Donne. Edited from the old editions and numerous manuscripts with introductions $\mathcal{E}^{\circ}$ commentary by Herbert J. C. Grierson M.A. Chalmers Professor of English Literature in the University of Aberdeen. Vol. I. The text of the Poems with Appendices [Vol. rr. Introduction and Commentary] Oxford: At the Clarendon Press. I9I2. $8^{\circ}$. Vol. I. pp. xxiv $+474+[2]$. Vol. Ir. pp. cliii + $[i i i]+276$. 
WALTON'S LIFE OF DONNE 



\section{WALTON'S LIFE OF DONNE}

\section{Bibliographical Preface}

Walton's Life of Donne, though written with an extraordinary grace and spontaneity, is not to be relied upon for accuracy of detail, in spite of the fact that the author declared in his note $\mathcal{T}_{0}$ the reader in the edition of 1658: "My desire is to inform and assure you, that shall become my Reader, that in that part of this following discourse, which is onely narration, I either speak my own knowledge, or from the testimony of such as dare do anything rather than speak an untruth." The Life appeared in its first form in the prefatory matter to the 80 Sermons, I640, which was edited by the younger Donne. Though considerable additions were made in later issues, this original form of the Life remained, except in detail, unaltered. The first separate issue of the Life was published in I 658 and this contained, as Walton says in the dedication, "fewer blemishes and more ornaments than when 'twas first made publique." The dedication was addressed to Sir Robert Holt, grandson of John King, Bishop of London, and nephew of Henry King, Bishop of Chichester, friend and executor of Donne, who warmly commended Walton's Life of Donne in a letter printed at the beginning of the 1670 edition of the Lives. The chief additions made to the Life in 1658 are noted under the entry following.

In 1670 Walton included the Life of Donne in the well-known volume of Lives ${ }^{1}$, which passed through several editions in the seventecnth century

1 The Lives of Dr. John Donne, etc...W'ritten by Isanc Walton...London, Printed by Tho. Newcomb for Richard Marriott... I670. $8^{\circ}$. Contains portrait by Lombart.

J. D. 


\section{30 Bibliography of Fobn Donne}

and has been so many times reprinted since; I have made no attempt to deal with the bibliography of this volume. The actual account of Donne's life underwent very little change in this edition, but the Epistle Dedicatory and the note $\mathcal{T}_{0}$ the reader were omitted; instead of these there was inserted an Introduction consisting of the first paragraphs of the Life and a passage from To the reader. The letters printed at the end of the edition of 1658 were omitted, but part of one of them and an extract from a new one were incorporated in the text (see no. 61). There were also added "An hymn to God, my God, in my sickness. March 23, I630," and Walton's "Elegy on Dr. Donne. April 7, I632." I have not seen copies of the second and third editions of the Lives, but the fourth edition, published in 1675 , contains an important addition in the form of a long account of Donne's vision of his wife seen while he was in Paris in I6 12, together with the verses entitled "A Valediction forbidding mourning" (Poems, I633, no. I00), which he had given her at parting.

An edition of the Lives was edited with important annotations by Thomas Zouch in $176^{1}$. Further annotations, useful though sometimes rather prolix, were added by T. E. Tomlins to an edition of the Life of Donne published in 1852 , which is the only separate reprint of this Life known to me and is therefore described under entry no. I07.

1 The Lives of Dr. John Donne, etc. By Isaac Walton. With notes and the Life of the Author. By Thomas Zouch M.A. York. 1796, $4^{\circ}$. and $1807,8^{\circ}$. 


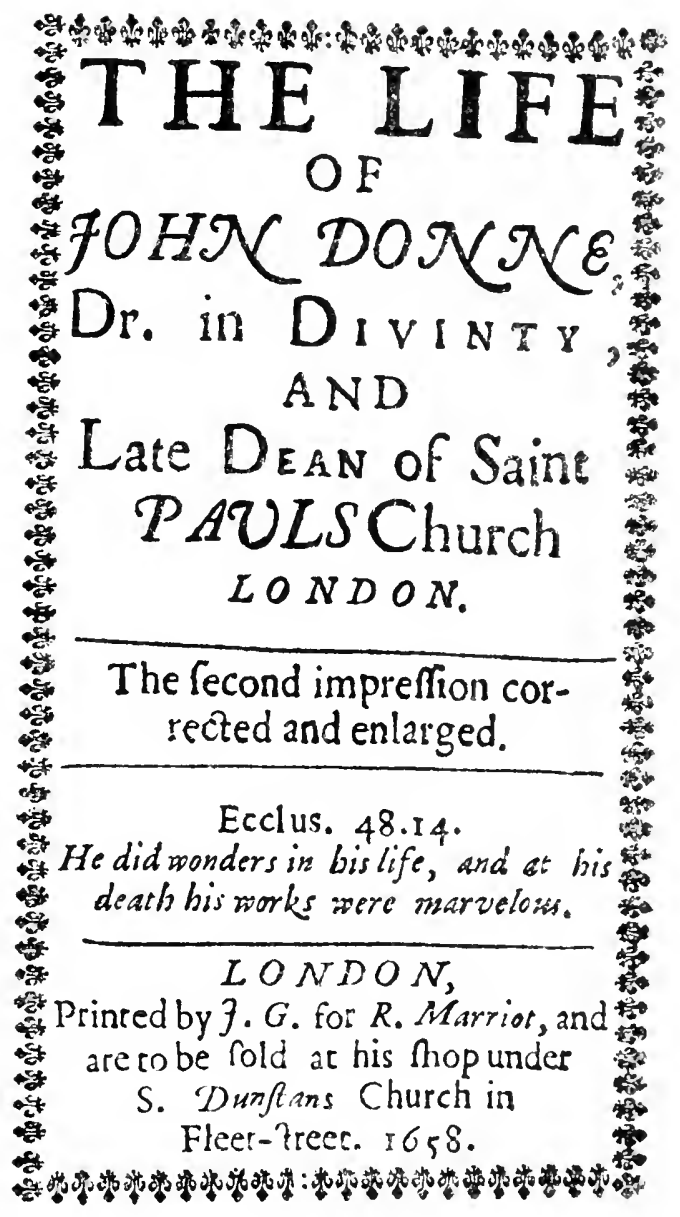

Title-page of no. 106. 
Title (within ornamental border): The life of John Donne, Dr. in Divinity, and Late Dean of Saint Pauls Church London. [rule] The fecond impreffion corrected and enlarged. [rule]

$$
\text { Ecclus. 48. } 14 .
$$

He did wonders in his life, and at his death his works were marvelous.

[rule]

London, Printed by J. G. for R. Marriot, and are to be fold at his thop under S. Dunftans Church in Fleet-1treet. $\quad$ $65^{8}$.

Collation: $\mathrm{A}-\mathrm{G}^{12} ; 84$ leaves.

Contents : Ar blank; A2 title; A3-A9a dedication To my Noble $\mathcal{F}_{3}$ honoured Friend Sir Robert Holt of Afton, in the County of WVarwick, Baronet signed Ifaac WValton; Agb blank; A Io To the Reader signed $I$. W.; A II-FII $b$ (pp. I-122) The life of Fohn Donne signed $I . W$.; FI I $b-G_{1} a$ (pp. 122-145) four letters from Donne; Gi 1 a-Gi2 (pp. 145-148) An Epitaph written by Dr. Corbet, Bi/hop of Oxford, on his friend Dr. Donne, and To the Memory of my ever desired Dr. Donne. An Elegy by H. King. B.C.

Frontispiece: Inserted between $A_{1}$ and A2. A bust of Donne within an oval as in the frontispiece to 80 Sermons, 1640 (no. 29), but without any of the surrounding design; it is printed from the same plate, which has not been retouched, though it shews signs of wear.

Note: Printed by John Grismond II (1639-1666). This edition, which is now very rare, is a reprint of the Life, which had been printed at the beginning of 80 Sermons, 1640, but it contains, besides several alterations, the following important additions: i. An account of Donne's marriage (pp. 15-18); ii. An account of Morton's attempt to persuade Donne to take orders (pp. 24-32); iii. Part of Chudleigh's Funeral Elegie (pp. 48-49); iv. Donne's grief at his wife's death (pp. 52-55); v. An account of the friendship of Henry King, Bishop of Chichester, and his proffered benefaction (pp. 67-72); vi. A relation of Donne's pleasure at hearing his Hymn sung; his seal; an enumeration of his friends; George Herbert and the lines that passed between them (pp. 77-85); vii. Donne's bequests (pp. 90-92); viii. An account of the making of the portrait of Donne in his shroud and of the stone effigy in St Paul's; ix. Four letters from Donne are printed together at the end (see no. 58).

Copies: BM, BLO.

Trinity College, Cambridge (no portrait).

G. L. Keynes. 
The Life of John Donne, D.D. Late Dean of St Paul's Church, London. By Izaak Walton. With some original notes, by An Antiquary. London: Published by Henry Kent Causton,...[1852]. (The Contemplative Man's Library for the Thinking Few) $8^{\circ}$. pp. iv +164. Note: The annotations are by Thomas Edlyne Tomlins, an antiquary well known at that period (see $N$. and $Q$., Ser. 10. vi. pp. 228 and $33^{8}$ ) ; they include nine letters from the Loseley MSS., which had not previously been printed (see no. 64). This edition is scarce. 


$$
\text { . }
$$




\section{BIOGRAPHY AND CRITICISM}





\section{BIOGRAPHY AND CRITICISM}

[This list makes no pretence of being complete; the life by Walton is dealt with in the preceding section. Further critical matter will be found in the various recent editions of the poems, etc.]

Theatrum Poetarum, or a compleat collection of the poets,... By Edward Phillips...London... M.DC.Lxxv. I $2^{\circ}$.

pp. 106-7. A short account of Donne.

9 Danielis Georgi Morhofi Polyhistor Literarius Philosophicus et Practicus...

Editio secunda, priori multo correctior. Lubecae... M Dccxiv

Tome 1. p. 994 (Lib. vi. Cap. iv. § 18). A short account of Donne, mentioning his Poems, Devotions, and Biatbanatos. Quoted in full by Zouch in his edition of Walton's Lives. (40. 1796.) See also pp. $4^{1}$ and 120 of the present work.

The Lives of the Most Eminent English Poets. By Samuel Johnson. London. I $779.8^{\circ}$.

Vol. I. pp. I- 100. Life of Cowley (with references to Donne).

Memoirs of the Loves of the Poets. By Mrs. Amna Murphy Jameson. London. I $83 \mathrm{I}$.

Vol. 11. pp. 94-109. The Story of Dr. Donne and his Wife.

2 Lives of Eminent and Illustrious Englishmen. By G. G. Cunningham. 1836.

Vol. 111. p. 242. John Donne.

J. D. 
I 3 Lowe's Edinburgh Magazine. Vol. I. I 846.

pp. 228-236. Gallery of Poets: No. I. John Donne.

I 4 Celebrated Friendships. By Mrs. K. B. Thompson. London. I86I. Vol. I. pp. 297 ff. Magdalen Herbert and Dr. Donne.

I 5 The Leisure Hour. Vol. xir. I 864. pp. 555-558. Dr. Donne (biographical sketch).

I 6 The classic preachers of the English Church. Lectures delivered at St. James' Church in 1877 . With an introduction By John Edward Kempe, M.A....London :... I $877.8^{\circ}$.

pp. I-26. Donne, the poet-preacher. By J. B. Lightfoot, D.D.

I 7 The Nineteenth Century. Vol. vil. I 880.

pp. 845-863. John Donne. By W. Minto.

I 8 The Argosy. Edited by Mrs. Henry Wood. Vol. xxxir. I88I. pp. 299-305. John Donne. By Alice King.

I 9 A History of English Literature in a Series of Biographical Sketches. By W. F. Collier. London. I 890 .

pp. $168 \mathrm{ff}$. John Donne.

I 20 Gossip in a Library By Edmund Gosse London William Heinemann. I 89 I. $8^{\circ}$. pp. [xii $]+337$.

pp. 55-64. Death's Duel (an essay on).

I 2 I The New Review. Vol. Ix. I 893.

pp. 236-247. The Poetry of John Donne. By Edmund Gosse.

I 22 New Studies in Literature. Boston $\mathcal{F}^{2}$ New York. I 895.

pp. 90-120. The Poetry of John Donne. By Edward Dowden (also in the Fortnigbtly Review, N.S. vol. XLviI. p. 721 ).

I 23 Studies and Notes in Philology and Literature. Vol. v. Boston. I 896. (Harvard Univ. Studies: Child Memorial Volume.)

p. 3. 'The Text of Donne's Poems. By C. E. Norton. 
4 John Donne, sometime Dean of St. Paul's A.D. I621-1631 by Augustus Jessopp, D.D....With two portraits...London 1897 [Leaders of Religion series] $8^{\circ}$. pp. $x+[i i]+239+[\mathrm{r}]$.

15 The Quarterly Review. Vol. clxxxv. 1897.

pp. I 73 ff. Fathers of Literary Impressionism.

16 The Life and Letters of John Donne Dean of St. Pauls Now for the first time revised and collected by Edmund Gosse... With portraits, etc. In two volumes...London William Heinemann $18998^{\circ}$. Vol.. pp. xxii $+318+[2]$. Vol. is. pp. viii $+39 \mathrm{I}+[\mathrm{I}]$.

17 The Fortnightly Review. N.S. Vol. Lxvi. 1899.

pp. 734-745. John Donne. By Arthur Symons.

18 A Group of Old Authors. By Clyde Furst. Philadelphia. I 899.

Ch. I. A Gentleman of King James' Day. Dr. John Donne.

19 The National Review. Vol. xxxiv. 1899.

pp. 595-6r3. John Donne. By Leslie Stephen.

The New World. Vol. Ix. I 900.

pp. 35 ff. John Donne Poet and Preacher. By J. W. Chadwick.

II The Quarterly Review. Vol. cxcir. I900.

pp. 217-240. John Donne and his Contemporaries.

12 The Temple Bar. Vol. cxxi. 1900.

pp. 614-628. John Donne. By H. M. Sanders.

13 Notes and Queries. 9th Series. 190I.

Vol. vir. p. 183. References in early English literature to Dr. Donne.

14 Beiträgen zur Neueren Philologie. Wien und Leipzig. 1902. (Jakob) Schipper Festschrift.)

p. 400. Über den Vers bei Dr. John Donne. Von Rudolph Richter. 


\section{40 Bibliography of Fobn Donne}

I 35 Religio Laici. By Canon H. C. Beeching. London. I 902. Article on Walton's Life of Donne.

I36 A History of English Poetry. By W. J. A. Courthope. London. 1903. $8^{\circ}$. Donne.

Vol. III. ch. viii. pp. I47-I68. The School of Metaphysical Wit: John

I 37 Platonism in English Poetry of the sixteenth and seventeenth centuries. By John Smith Harrison. Columbia Univ. Press. New York. I 903.

Contains references to Donne's conceptions of Love and Woman.

I 38 Beiträge zur Kenntnis des Stils von John Donne in seinen 'Poetical Works.' Inaugural-Dissertation...vorgelegt von Wilhelm Trost aus Frankenburg ...Marburg... I 904. $8^{\circ}$. pp. [iv] $62+[2]$.

I 39 Notes and Queries. Ioth Series. I 905-6.

Vol. Iv.pp. 41, I21, 201, 302. Vol.v.pp. 301, 382. Vol. vi. p. 22. Montaigne, Webster, and Marston: Dr. Donne and Webster. By Charles Crawford.

I 40 Conversations of Ben Jonson with William Drummond of Hawthornden. Edited by Philip Sidney, F.R.Hist.S. London. I 906. $8^{\circ}$.

Important references to Donne. (First edited for the Shakespeare Society by Laing, I 842.)

I 4 I The rhetoric of John Donne's verse. By Wightman Fletcher Melton... Baltimore... I906. $8^{\circ}$. pp. viii +209 .

142 The Cambridge History of English Literature. Vol. IV. I 909.

Ch. xI. pp. 196-223. John Donne. By H. J. C. Grierson. (Bibliography, pp. 488 - 490.)

Ch. xIr. pp. 224-24I. The English Pulpit from Fisher to Donne. By the Rev. F. E. Hutchinson, M.A.

I 43 The Modern Language Review. Vol. viI. I9I2.

No. I. (Jan.). Donne's Sermons, and their Relation to his Poetry. By Evelyn M. Spearing. 
4 The Times Literary Supplement. Jan. 30, 1912.

pp. 37-38. The Poems of John Donne.

5 The Nation. Vol. xil. Feb. 1913.

pp. 825-6. John Donne, the Elizabethan. [By Rupert Brooke.]

6 Poetry and Drama. Vol. r. no. 2. June, 1913.

pp. 185-r88. John Donne. By Rupert Brooke.

7 The Modern Language Review. Vol. virr. 1913.

No. iv. (Oct.) pp. 468-483. A Chronological Arrangement of Donne' Sermons. By Evelyn M. Spearing. 

APPENDICES I-V 



\section{APPENDIX I}

\section{WORKS BY JOHN DONNE, D.C.L.}

\section{Preface}

John Donne the younger was born while his father was living at Pyrford in Surrey in 1604. He was sent to Westminster School, and in 1623 was elected a student at Christ Church, Oxford. Nothing is known of his life during the next ten years except that in I 629 his father had destined him for the Church, as appears from a passage in a letter to Mrs Cockain, in which he tries to console her for the death of her son by writing: "Since I am well content to send one son to the Church, the other to the Wars, why should I be loth to send one part of either son to heaven and the other to earth'." In I63+ he was still at Oxford and a somewhat unpleasant incident is said to have taken place there; it is related $^{*}$ that in a fit of temper he struck a small boy with his riding whip, the child afterwards dying as the result of his injuries. Donne was tried at Oxford in August I 634 for manslaughter, but he was acquitted owing to the uncertainty of the medical evidence. Possibly as the result of this incident he proceeded soon afterwards to Padua and there took the degree of D.C.L. He returned in 1637 and was incorporated a D.C.I. at Oxford on June $30,1638^{3}$. It was about the same time that he fulfilled his father's wishes by taking orders. He soon obtained preferment and on July Io, I 638 , he was presented by the King to the rectory of High

1 Tobie Matthew collection, no. 36 .

Gosec, ii. 308.

${ }^{3}$ Gosse, ii. 311.

J. D. 


\section{46 Bibliography of Fohn Donne}

Roding in Essex. On June I0, I639, he was presented to the rectory of Fulbeck in Lincolnshire, and about the same time to the rectory of Ufford, Northamptonshire, in the diocese of Lincoln ${ }^{1}$. He continued to rise in the Church and in I648 was chaplain to the Earl of Denbigh", to whom he dedicated the Fifty Sermons of I 649 . From about the year I 640 he lived in Covent Garden and he may have been incumbent of some church in that district. His petition of 166 I on behalf of the inhabitants of Covent Garden is recorded here under entry no. ${ }_{4} 8$. He died at the age of 58 in 1662 , and his will (see no. 150) was printed as a broadside in February of the same year.

Meanwhile, from the year I 640 to the time of his death, he had been shewing considerable literary activity, and it is owing to his energy that the greater portion of his father's writings has been preserved for us. There is evidence that the elder Donne had early thought of his son as his future literary executor, for he had written to a friend from Chelsea on November 25, I625: "I have revised as many of my sermons as I have kept any note of, and I have written out a great many, and hope to do more. I am already come to the number of eighty ${ }^{3}$, of which my son, who, I hope will take the same profession, or some other in the world of under-

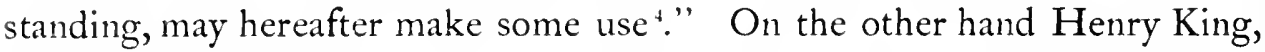
Bishop of Chichester, in a long letter written in I6 0 to Izaak Walton, which was prefixed to the Lives in 1670, states that Donne professed before several witnesses on his death-bed "that it was by my restless importunity, that he had prepared them [the sermons] for the press"; he declares also that three days before his death Donne had made him his executor and given him the sermons, his sermon notes, "and his other papers, containing an extract of near Fifteen hundred Authors." $\mathrm{He}$ further hints that the younger Donne, using Walton as a go-between, had filched these papers from his keeping, and this was, indeed, probably the case, for in his will Donne makes the following bequest: "To the

1 Gosse, ii. 3 I I. 2 Gosse, ii. 320.

${ }^{3}$ This does not refer to the 80 Sermons of $16+0$, since twenty-six of the sermons in that collection are dated later than 1625 , the year in which this letter was written. This was first pointed out by Mr F. E. Hutchinson in the Camb. Hist. of Eng. Lit. iv. 240-1.

4 Gosse, ii. 3 IO. 
Reverend Bishop of Chichester I return that Cabinet that was my Father's ...and all those Papers which are of Authors analysed by my lather.' Donne states in his preface to the XXVI Sermons of I 660 that "upon the death of my father...I was sent to by His Majesty of Blessed Memory to recollect and publish his Sermons"; this may or may not have been true.

Donne's petition of 1637 to the Archbishop of Canterbury shews that already before this he had made an attempt to gain control of those others of his father's writings which had been published without his authority. The petitioner states "that since $y^{\mathrm{e}}$ death of his Father there hath bene manie scandalous Pamflets printed, and published, under his name, which were none of his, by severall Boocksellers, withoute anie leave or Autoritie; in particuler one entitoled Juvenilia, printed for Henry Seale; another by John Marriott and William Sheares, entitoled Ignatius his Conclave, as allsoe certaine Poems by $\mathrm{y}^{\mathrm{e}}$ sayde John Marriote, of which abuses thay have bene often warned by your $\mathrm{Pe}^{\mathrm{tr}}$ and tolde that if thay desisted not, thay should be proceeded against beefore your Grace, which thay seeme soe much to slight, that thay profess soddainly to publish new impressions, verie much to the greife of your $\mathrm{Pe}^{\mathrm{tr}}$ and the discredite of $\mathrm{y}^{\mathrm{e}}$ memorie of his Father." The Archbishop granted Donne's petition by calling upon those concerned to desist from their illegal practices, but his authority was ineffectual, and it was only in I 650 that Donne acquired control of his father's poems, in which year he published an edition with a dedication to Lord Craven. In 1644 he published his father's Biathanatos, and his presentation copies of this book with the letters contained in them have already been noticed (see pp. 62-63). In I649 he issued the second volume of Fifty Sermons, and in an address to the Lords Commissioners of the Great Seal he indicates that he had not undertaken the publication of the sermons without some official reward. In a letter already quoted (p. 6.3) of about 1644 he shews that he had had these sermons ready and entered at Stationers' Hall, but that he had kept them back from far of persecution by the Commonwealth government. In 165 I he published his fither's Letters to several persons of honour, and in the same year he prepared the Essays in Divinity, which he incorporated in 1652 in the volume of Jurenilia

1 Printed in full by Grierson, ii. Ixvi. 'The petition is preserved in the Record (oflice. 


\section{Bibliography of Fobn Donne}

together with a reprint of Ignatius his Conclave. In I660 he issued the final volume of $X X V I$ Sermons, this time at his own expense. In the same year he also edited both Sir Tobie Matthew's Collection of Letters, and a collection of poems by the Earl of Pembroke and Sir Benjamin Ruddier ${ }^{1}$. His own work, entitled Donne's Satyr (no. I 49), was published in I662; it consists of somewhat obscene, though not very amusing, pleasantries.

The younger Donne's character has usually been held somewhat in contempt, and it is certain that he gives no particular sign of intellectual distinction and does not appear to have been remarkable either for honesty or for morality. Anthony a-Wood has characterised him as "an atheistical buffoon, a banterer, and a person of over free thoughts, yet valued by Charles II." The following little-known extracts may be quoted from two of his letters, which are unfortunately not dated:

"I receaued a letter from $\mathrm{y}^{\mathrm{r}} \mathrm{Lp}$. this weeke, but it was rauished from mee by a verie handsome Ladie, who after shee had taken the pleasure of readinge it, tore it and burnt it; a little more familiarity would haue giuen me a iust occasion to haue clapt her breech, and then I must haue faught with Sir Lionell the husband, for it is now cominge into fashion?."

"I hope, likewise, you haue not the feare of God before your eyes, and being ashamed of that, make Hine-head and Lob-lane your excuse ; if you haue, pray my Lord speake plaine, that if you are turned sainct, we may deliuer you up to Satan, and keepe these Angels to ourselues.".

We are now, however, prying into his private life, and we must leave him with a remembrance of the gratitude due to him for his labours on behalf of the memory of his father.

1 Poems, Written by the right honourable William Earl of Pembroke... Many of which are answered by way of Repartee, by $S^{r}$ Benjamin Ruddier, Knight. With several distinct poems... London, Printed by Matthew Inman, and are to be sold by James Magnes...r66o. $8^{\circ}$.

${ }^{2} N$. E Q.S. 3. iv. 149 .

${ }^{3}$ Ibid. 
To the Right Honorable, the Lord Chancellor, the humble Petition of Covent Garden. [I66I.] Broadside, 3I $\times 2$ I $\mathrm{cm}$.

Note: A petition for the removal of one, Dr. Babre, from a position of authority, by reason of his unjust persecutions. It is signed by Bedford Berry, St. An. Shandsis, Piazza King, Henrietta Belford, Fames Ruffel, Charles York, Bridges Bowftreet, Amen Manto, Todos Autros'. The copy described is inscribed below in a contemporary hand:

$$
\text { Authore D. Dre. Donne Fun. } 166 \mathrm{I} \text {. }
$$

John Donne the younger lived in Covent Garden.

Copy: BLO.

\section{DONNE'S SATYR.}

8.. $\mathbf{1} 662$

Title : Donne's Satyr. Containing

I. A hort Map of mundane Vanity

2. A Cabinet of Merry Conceits

3. Certain pleafant Propofitions, and Queftions, with their merry Solutions and Anfwers.

Being very Ufeful, Pleafant, and Delightful to all ; and Offenfive to none. [rule] By Jo. Donne. [ornament between rules]

London, Printed by R. W. for M. Wright, at the Kings Head in the Old-Bailey, I662.

Collation: $\mathrm{A}-\mathrm{I}^{8} ; 72$ leaves.

Contents: A1 frontispiece (a satyr); $\mathrm{A}_{2}$ title; $\mathrm{A}_{3}-\mathrm{A}_{7}$ The Epiftle Dedicatory; A8-18a (pp. I-I29) text; I8b Books printed for M. W Wright. Folding sheet inserted between $\mathrm{B} 6$ and $\mathrm{B} 7$.

Note: Printed by (?) Robert White (1639-1667).

Copy: BM.

i.e. "All the rest"; the other names are evidently fictitious, several of them being made up from the names of various streets round Covent Garden. 


\section{I $50 \quad$ Bibliography of John Donne}

Dr. Donne's Laft Will and Teftament. July 21. 1657...Printed, February 23. I662. Broadside, with black border, $39 \times 26 \mathrm{~cm}$.

Note: Donne makes Ferome, Earl of Portland, his executor, and the will was witnessed by the Earl of Marleburgh and Will. Glascocke, Noveniber 2, I66I. The following extract is of interest :

“To Mr. Isaac Walton, I give all my writings under my Father's hand, which may be of some use to his Son, if he makes him a Scholar. To the Reverend Bishop of Chichester, I return that Cabinet that was my Father's, now in my DiningRoom, and all those Papers which are of Authors Analysed by my Father ; many of which he hath already received with his Common-Place Book, which I desire may pass to Mr. W Walton's Son, as being more likely to have use for such a help, when his age shall require it."

Copies: BM, BLO.

Trinity College, Cambridge. 


\section{APPENDIX II}

\section{WORKS BY JOHN DONE}

\section{Preface}

The two dull and unimportant works by John Done called Polydoron and The Ancient History of the Septuagint have been persistently attributed to Donne, some colour being lent to this attribution by the fact that the publishers have falsely described Done on the title-page of the second edition of The History of the Septuagint as "the Learned and Reverend Dr John Done, late Dean of St. Pauls." An inquiry concerning Done, which was made in Notes and Queries (Ser. 6. vi. 4), elicited from the late Dr Augustus Jessopp the following reply: "It is one of the "curiosities of literature' that this latter volume [The History of the Septuagint] should have been attributed to the Dean of St. Paul's by every editor of Walton's Lives till the mistake was pointed out by me in 1855 . It is a trumpery production, and could never be set down to the great dean by any one at all familiar with his writings. I tried to find out something about the man Done twenty-five years ago, but I cannot lay my hands on my notes; my impression is that he was a needy schoolmaster, who was employed by the booksellers." ( $N$. E Q. Ser. 6. vi. 95, July, i 882.) A long letter from Done on alchemy is preserved in the Bodleian (Ashm. MS. $1+15$, f. 196 ). 
Title: Polydoron : or a mifcellania of Morall, Philofophicall, and Theologicall fentences. [rule] By Iohn Done. [rule and device] Printed at London by Tho. Cotes, for George Gibbes dwelling in Popes-head Alley at the figne of the Flower de Luce. I63I.

Collation: $\mathrm{A}-\mathrm{I}^{12} \mathrm{~K}^{4} ; \mathrm{I} 12$ leaves.

Contents: A I blank except for sign.; A2 title; $\mathrm{A}_{3}-\mathrm{A}_{4}$ a (both with sign. $\mathrm{A}_{4}$ ) $\mathcal{T}_{0}$ the Reader signed I. Done; A4b blank; $\mathrm{A}_{5}-\mathrm{K}_{4}$ (pp. $\left.\mathrm{I}-216\right)$ text (errata at bottom of $\left.\mathrm{K}_{+} b\right)$.

Note: Some copies have a leaf with dedication to the Earl of Dover and with signature $A_{3}$ inserted between $A_{2}$ and $A_{3}$. In the $B_{M}$ copy this appears to be printed on a sheet of two leaves together with the first leaf of $\tau_{0}$ the Reader, this sheet being inserted between $\mathrm{A}_{2}$ and $\mathrm{A}_{4}$. I am unable to explain the discrepancy. The device on the title-page of a fleur-de-lis within a border of leaves and berries is recorded as no. 415 in McKerrow's Printers' and Publishers' Devices, London, I9I3.

Copies: BM, ULC.

Emmanuel College, Cambridge.

152 POLYDORON.

12 . 1650

Title (within ornamental border): A mifcellanea of morall, theologicall, and philosophicall fentances; [rule] Worthy obfervation. [ornament between rules]

Printed for Iohn Sweeting, At the Angel in Popes-head-alley, I650.

Collation: As in no. I5I.

Contents: A I title; A2 (with sign. A3) dedication To the Rigbt Honourable Henry, Earl of Dover, Ece. signed Iobn Done; $\mathrm{A}_{3}-\mathrm{K}_{+}$as in preceding entry.

Note: This is a reissue of the preceding entry. $\mathrm{A}_{1}$ and $\mathrm{A} 2$ are both cancel leaves, consisting of a new title-page and a dedication, which had been inserted in some copies of the first issue.

Copy: BLO.

I 53 HISTORY OF THE SEPTUAGIN'T.

8.. 1633

Title (within double lines): The Auncient Hiftory of the Septuagint. Written in Greeke, by Arifteus I900. Yeares since.... Newly done 
into English [rule] By I. Done. [rule] Tempora, Tempera, Tempore. [rule]

London: Printed by N. Okes. 1633.

Collation: $\mathrm{A}-\mathrm{O}^{8} ;$ in 2 leaves.

Contents: A I blank; A2 title; A3-A6a To the Intelligent General Reader; A66-A 8 The Elenchus, or Contence of the Following Booke; $\mathrm{BI}-\mathrm{O} 8$ (pp. 1-80, 89-184, 189-219) text, pp. I- Io being headed: Certaine Pracognita.

Note: A number of pages, as noted above, are omitted from the pagination.

Copies: BM, ULC.

Edmund Gosse; G. L. Keynes.

4 HISTORY OF THE SEPTUAGIN'T.

$12^{\circ} \cdot 1685$

Title (within double lines): The ancient hiftory of the Septuagint. Written in Greek by Arifteus near two thoufand years ago... [rule] Firtt Englifh'd from the Greek, by the Learned and Reverend Dr. John Done, late Dean of St. Pauls. [rule] Now Revifed, and very much Corrected from the Original. [rule]

London, Printed for W. Henfman, and Tho. Fox, Bookfellers in Weftminfter-Hall. I 685.

Collation: $\mathrm{A}-\mathrm{I}^{12} ; 108$ leaves.

Contents: A I blank; A2 title; $\mathrm{A}_{3}-\mathrm{A}_{5} T_{0}$ the Reader; $\mathrm{A}_{6}-\mathrm{A}_{7}$ The Elenchus; A8-AI2 (pp. I-Io) Certain Pracognita; BI-Ir2 (pp. I-192) text.

Note: Done is falsely described on the title-page of this edition (see my preface).

Copies: BM, ULC.

Jesus College, Cambridge.

G. L. Keynes. 


\section{APPENDIX III}

\section{BOOKS FROM DONNE'S LIBRARY}

[I have noticed copies of the following works, which contain Donne's autograph, and presumably are from his library. Probably there are many more in existence.]

I 55 Sutcliffe, M. Subversion of Robert Parsons, his confused and worthlesse work, entituled a Treatise of Three Conversions of England. I606. $4^{\circ}$.

I 56 Ormerod, O. Picture of a Puritane, or a Relation of the Opinions, Qualities and Practices of the Anabaptists in Germany, and of the Puritans in England, and Discovery of Puritan-Papisme. 1605. $4^{\circ}$.

I 57 Answere made by one of our Brethren, a Secular Priest, now in Prison, to a Fraudulent Letter of M. George Blackwels, in commendation of the Jesuite in England. I602. $4^{\circ}$.

I 58 Articles of Peace, Entercourse, and Commerce, concluded by James I. with Philip III. of Spaine. 1605. $4^{\circ}$.

I 59 Fenton, R. Answere to William Alablaster, his Motives. I $599 . \quad 4^{\circ}$.

I60 Perkins, W. Second Part of the Reformation of a Catholic Deformed. 1607. $4^{\circ}$.

I6 1 An Answer unto Mr. Perkin's Advertisement. $4^{\circ}$.

I 62 Covell, W. Defence of R. Hooker's Ecclesiastical Politie. I603. $4^{\circ}$.

I 63 Holland, T. Panegyris D. Elizabethæ Reginæ, a Sermon in Paul's Church, 17 th. November, 1599. Oxford. I600. $4^{\circ}$.

I64 Hyll, A. Defence of the Article, Christ Descended into Hell, against one Alexander Humes. 1592. $4^{\circ}$.

[The above ten tracts are bound in one volume in original vellum; they contain Donne's signatures and numerous references in his autograph. Offered in a catalogue issued by Messrs Pickering and Chatto, I902, item I 809.] 
Gentilis, Albericus. Regales Disputationes tres. Londini Apud Thomam Vautrollierum. I605. $4^{\circ}$.

D'Aluin, Stephanus. Tractatus de Potestate Episcoporum, Abbatum, etc. Parivii, apud Franciscum Huby. $1607.4^{\circ}$.

[The two tracts above have Donne's signature at the bottom of the title-pageand an Italian inscription: "Per Rachel ho seruito \& no per Lea '," at the top. See cat. 737, issued by Mr Tregaskis, Feb. 19 13.$]$

F[reher], M. Sulpitius; sive de æquitate commentarius, etc. I608. $4^{\circ}$.

[Contains Donne's autograph. Now in the BM, 501 . e. I0 (3).]

de Vineus, Petrus. Epistolarum libri vi. Ambergæ, Apud Johannem Schönfeldium. I609. $12^{\circ}$.

[Autograph and inscription as in nos. 165-166. In the possession of Mr Everard Meynell.]

1 This is not an exact quotation, but see Genesis, xxix. 25. 


\section{APPENDIX IV}

\section{A BOOK DEDICATED TO DONNE}

I69 Title: The lawyers Philosophy : or, law brought to light. Poetized In a Diuine Rhapfodie or Contemplatiue Poem. By Roger Tifdale, Gent. Sat Serò. [device]

At London printed for I. T. and H. G. and are to bee fold at the Widdow Goffons in Pannier Alley. 1622.

Collation: $\mathrm{A}-\mathrm{C}^{8} \mathrm{D}^{4} ; 28$ leaves.

Contents: Ar blank; A2 title; $\mathrm{A}_{3}-\mathrm{A}_{5}$ The Epifle Dedicatorie To the learned and reuerend Iobn Donne, D. of Diuinitie, Deane of the Catbedrall Cburch of $S^{t}$ Paule London, Roger Tifdale wifheth peace of Conficience in this world, and the ioy of the world to come; A6 To the learned and confiderate Reader; A7-D2 The Lawyers Philosophy; $\mathrm{D}_{3} \mathrm{~T}_{0}$ the defire of my 1'suth, and bope of mine Age, my young fonne Roger; $\mathrm{D}_{4}$ blank.

Note: The device on the title-page is the same as that found on the title-pages of the two editions of Donne's Juvenilia, 1633 (nos. 43, 44).

Copies: BM.

Edmund Gosse. 


\section{APPENDIX V}

\section{ICONOGRAPHY}

[This list is only intended to be a brief guide to the iconography of John Donne.]

A. Oil Paintings :

I. Bust, full face, with bare neck and a cloak round the shoulders. Circular. diameter $58 \mathrm{~cm}$. Painted in 1631, aet. 59. Painter unknown. Now in the dining-room at the Deanery of St Paul's Cathedral.

An engraving after this portrait was made by Lombart in $165 \mathrm{I}$ (see no. 5 below). The painting is reproduced in Gosse, frontispiece to vol. ii.

2. A replica or copy of no. I. Now in the Dyce collection at the Victoria and Albert Museum, where it is ascribed to Cornelius Janssen.

B. Stone Effigy:

3. Full-size effigy of Donne in his shroud; at his feet is an urn and above his head is a marble tablet with an epitaph written by himself. Carved in Italian marble by Nicholas Stone in I63I after the portrait, which had been drawn on a board by an unnamed artist shortly before Donne's death. The effigy was originally within the choir in the south aisle of old St Paul's, and was the only monument, which was saved intact from the fire of 1666; it is now in a corresponding position in the present Cathedral. For further particulars of this effigy, see Walton's Life of Donne, I658, pp. III-II4, and Gosse, ii. 280-288.

Engravings of the effigy were made by Marshall (110. 7 below) and by Hollar (no. 9 below). Photographs of it are reproduced in Gosse, rol. ii, facing p. 280.

C. Engravings :

4. I59I. Aet. I8. Bust, three-quarter face to right, in an oval $8 .+\times 6.4 \mathrm{~cm}$. Engraved in line and stipple by Marshall after an unknown painting; line, by Walton below. Used as frontispiece to the second edition of the Poims, 1635, and to several subsequent editions (see nos. 79-83). Reproduced an frontispiece to Gosse, vol. i, as frontispiece to present work, and clsewhere. 
5. 1631. Aet. 59. Bust in an oval, $10.2 \times 8.5 \mathrm{~cm}$. Engraved in line by Lombart after no. I or 2 above. Used as frontispiece to the Letters, $165 \mathrm{I}$ and 1654 (see nos. 55, 56); also in Walton's Lives, 1670 and 1675. Reproduced in Gosse, vol. ii, facing p. 80 , and elsewhere.

6. Donne's head in a shroud, within an oval, $11 \cdot 4 \times 8.5 \mathrm{~cm}$. Engraved in line by Droeshout after the stone effigy (no. 3 above) or the original drawing on a board. Used as frontispiece to Death's Duell, I6 32 (see nos. 24-26). Copied by Skelton for Walton's Lives, ed. Zouch, 1796, etc. Reproduced in Gosse, vol. ii, facing p. 300, in present work, facing p. 27 , and elsewhere.

7. Full-length in shroud, measuring, with decorations, $9.5 \times 5 \mathrm{~cm}$. Engraved by Marshall after the effigy in St Paul's. Used as frontispiece to the fourth and fifth editions of the Devotions, I634 and 1638 (see nos. 39 and 40). Reproduced in Pickering's edition of the Devotions, 1840 (see no. $4 \mathrm{I}$ ), and facing p. 45 of present work.

8. 1614. Aet. 42. Bust, three-quarter face to right, dressed in gown and ruff, within an oval, $9 \times 6.5 \mathrm{~cm}$. Engraved in line and stipple by Merian in the centre of the frontispiece to the 80 Sermons, 1640 (see no. 29). The original painting is unknown. The portrait alone was also used as a frontispiece to Walton's Life of Donne, 1658 (see no. 106). Copied by Skelton for Walton's Lives, ed. Zouch, 1796, etc. Reproduced in Gosse, vol. ii, facing p. I44, and facing p. 33 of present work.

9. Full-length in shroud, $30 \times 10 \mathrm{~cm}$. Engraved in line by Hollar after the effigy in St Paul's for Dugdale's History of St Paul's, 1658, p. 62.

10. Bust, three-quarter face to left, dressed in gown and ruff; rectangular, $9.6 \times 7.6 \mathrm{~cm}$. Engraved in line by A. Duncan after a drawing by G. Clint, A.R.A., "from an original picture in the possession of the Revd Dr Barrett."

A plate from Effigies Poetica, London, W. Walker, 1822, $8^{\circ}$; also india paper proofs on large paper. The original picture is not known to me. Reproduced in Gosse, vol. i, facing p. 304.

II. Bust, full-face, dressed in gown and broad linen collar, in an oval, $10.6 \times 8.6 \mathrm{~cm}$. Engraved in line and stipple by W. Holl, "from the original picture by Vandyke in the possession of F. Holbrooke, Esq." Used as frontispiece to Donne's Works, ed. Alford, 1839, vol. i (see no. 33). The head closely resembles that of the two oil paintings, nos. I and 2 above; the "original picture" is perhaps to be identified with no. 2, the dress having been slightly altered in the engraving.

12. Bust in an oval, $5.5 \times 4.2 \mathrm{~cm}$. Engraved by Alais after "a miniature painted in 1610 by Isaac Oliver." Used as frontispiece to Donne's Poems, ed. Grosart, 1872 , vol. i (see no. 98). The miniature is not known to me. 


\title{
LIST OF PRINTERS AND PUBLISHERS
}

\author{
INDEX
}


. 


\section{PRINTERS AND PUBLISHERS, 1607-I7I9}

The numbers refer to the entries in the bibliggraplyy

Alsop, Bernard 25, 26

Bedell, G. 57

Bennet, Thomas 62

Bradwood, M. 75

Burre, Walter 1

Cambridge, University Printers 27

Collins, James 11

Collins, T. 57

Cotes, Thomas 151

Creede, Thomas 73

Dawson, John 47

Dewe, Thomas 76, 77

Fawcet, Thomas 25,26

Fisher, Benjamin 24, 25, 26

Fletcher, James $30,55,56,83$

Fletcher, Miles $7,29,30,78,79,80,81$

Fox, Thomas 154

Fussell, Nicholas 27

G., H. 168

Gibbes, George 151

Gosson, Widow 168

Greene, Charles 39

Grismond, John, II 106

Harper, Thomas 24

Haviland, John 23, 28a

Hensman, William 154

Herringman, Henry 59,84

Horne, Thomas 62

Jones, Thomas $12,13,14,15,16,17,18,19$, $20,21,22,34,35,36,37,38$

Lisle, Laurence 73

Lownes, Humfrey 72
Macham, Samuel 74, 75

Magnes, James 31

Marriot, John $8,9,30.78,79,80,81.82$

Marriot, Richard 29, so, 55, 60, 61, 82, ic6

Matthewes, Augustin 15, 16, 19, 34, 36, 39 . 40, 76

Maxey, Thomas 50

Meredith, Christopher 23

Milbourne, Robert 28 a

More, Richard 4, 5, 7

Moseley, Humphrey 27, 45, 46, 48

Newcomb, Thomas $31,32,45,46,60,61, x_{4}$

Okes, Nicholas 4, 5, 153

P., M. 2sb

Purslowe, Elizabeth 43,44

Redmer, Richard 24

Royston, Richard 29, 30,40

S., W. 70

Saunders, Francis 62

Seyle, Henry 43, 44

Sheares, William 8,9

Stafford, John $28 \mathrm{~b}$

Stansby, William 1, 12, 13, 77

Stephens, Philemon 23

Sweeting, John 56, 83, 152

T., I. 168

Taylor, W. 86

Thorppe, Thomas 69

Tonson, J. 86

Villerianus, Thomas 3

White, Robert 149

Wright, M. 149 


\section{INDEX}

\section{The numbers refer to the pagination}

Aberyhatch, letters from Donne at $7 \&-80$, 114

Acts, i. 8, sermon on 22, 23

Addington, Mr Samuel, miniature in possession of 123

Adrocates' Library, Edinburgh, books in the 6,66 , so

Alais, W. J., engraving by 123,158

Alford, Henry, Donne's Morks edited by 38

All Souls College, Oxford $34,+2,54,66$, I I 3 , 119

Almanack, Bretnor's 100

Amiens, letters from Donne at $78-8 \circ, 8 s$, 114

Anderdon, J. H., MSS. in possession of 88

Anderson, R., Poems edited by 121

Andrews, Dr, latin letter to 114

Ankerum, Earl of, letter to 75

Anniversaries 93-101

Arber's Transcripts 105-106

Argosy, article in 138

Aspley, Master, licence granted by 106

Autograph, John Donne's I 54-155

B., Mr R., elegy by 112

Babbott, Mr F. L., introduction by 124

Barlowe, D., Answer to The Judgment of a Catholike Englishman 4

Barrett, Dr, portrait in possession of $15^{8}$

Bartlett, Miss H. C. $14,42, I_{1}, I_{1} 17$

Basse, William, epitaph on Shakespeare 109

Beaumont, Francis, Poems 109

Bedford, Lady, elegy to 1 i 1 letters to 75,76 , I I I verses to 108, I 18

Beeching, Canon H. C., article by I 40

Bell's edition of the Poems 12 I

Biathanatos $59-66$

Binyon, Mr Laurence 113

Biography and criticism I $35-1+1$
Bodleian Library, Oxford, books in the 6, 11 , I $5,16,21,23,24,26,28,34,35,37,44,54$, $57,65,70,80,98,100,113,115,116,118$, I $32,149,150,152$

Bohemia, Queen of, letters to $41,82,83$

Book of Ayres, Corkine's 92, 110

Booksellers, 1607-1719, see p. I6 I

Boston, Poems published at 122

Boulstred, Mrs, elegy on ${ }_{1} I_{4}$ verses to 107

Boys, John, reference to Pseudo-martyr +

Bray, William, Imprimatur signed by 45

Bretnor, Thomas, Almanack 100

British Museum, books in the 6, 11, 12, 14 , I $5,16,21,22,23,24,25,26,28,29,31,32$, $34,35,37,42,44,45,54,56,57,65,66,70$, So, $81,84,85,98,100,113,115,116,118$, $119,121,132,149,150,152,153,155,156$

Brogden, James, Illustrations of the Liturgy $3 \mathbf{I}$

Brooke, Basil, verses to 1 o 8

Brooke, Christopher, rerses to 107,108

Brooke, Rupert, articles by $14 \mathrm{I}$

Brooke, Samuel, verses to 108

Brown, Thomas, Imprimatur signed by 33

Browne, Thomas, elegy by i 11

Browne, Sir T., elegy ascribed to I I I

Browne, William, poem by i 21

Brussels, letter from Donne at 77

Brydges, Sir G., letter to 77,78

Buckingham, Duke of, dedication to 2 I letters to $4 \mathbf{1}, 8_{1}, 8_{2}, 8_{7}, 88$

Cabala 81

Cambridge, Six sermons printed at 29

Cambridge History of English Literature 140

Cainden Society 87

Campbell, Thomas, Poems edited by 122

Canterbury, Archbishop of, letter to $8_{3}$

Canterbury Cathedral library i 6, I 18

Carew, Lady, verses to 108 
Carew, Sir Lucius, elegy by 112

Carew, Sir Nicholas, letter to 88

Carew, Thomas, elegy by 112

Carey, Carie, see Carew

Carleton, Sir Dudley, letter to 87

Carlile, Lucy, Countess of, dedication to 82

Carlile, Lord, letter from $\delta_{3}$

Carre, see Ker

Carter, The Rt Rev. Edward, letter to, from John Donne, jun. 62

Causton, H. K., Walton's Lifi published by 133

Chadwick, J. W., article by 139

Chalmers, Alexander, Poems edited by 122

Chambers, E. K., Poems edited by 124

Characters, Overbury's 92

Charles I, first sermon preached to 24

Charles II, dedications to 33, 36

Charles, Prince of Wales, dedication to 42

Chelsea, Sermon of commemoration preached at 26

Chelsea, letter from Donne at $s \&$

Chew, Mr Beverley, library of 42 , I I5, I17

Chilsey, see Chelsea

Christ Church, Oxford 31, 34, 35, $44,57,66$, 70,80 , I $13,116,118$, I I 9

Christ's College, Cambridge $34,35,37,66$, I 13, I I 5

Chudleigh, I, elegy by 115

Clare College, Cambridge 66, 1 i 3

Clarendon Press, Poems published by $\mathrm{I} \geq 5$

Clint, G., portrait by 158

Cockain, Mrs, letters to 80,84

Collier, W. F., biographical sketch by 138

Cologne, letter from Donne at $8_{4}$

Compleat Angler, Walton's 109

Conclave Ignati $7-16$

Constable, Henry, pocm by is 5

Contemplative Man's Library 133

Conway, Secretary, letter to 88

Cook, engraving by 121

Corbet, Dr, elegy by 111,132

Corkine, William, Book of Ayres 92

Cornelius, Lucius, Monarchia Solipsorum 16

Corpus Christi College, Cambridge 80,113

Corpus Christi College, Oxford 6, 15,44, 54, 66,113

Coryat's Crudities, verses on $91-9^{2}$, I 16

Cotton, Robert, letters to $87-88$

Courthope, W. J., essay by 140

Covent Garden, petition of 149

Crashaw, Richard, verses by 85

Craven, Lord, dedication to 117

Crawford, Charles, articles by 140

Crudities, Coryat's $91-92,116$

Cunningham, G. G., life by 137
Daniel, device representing 34

Danvers, Lady, Sermon of Commemoration of $2 i s$

Darnelly, Daniel, elegy by 115

Davison, Francis, verses by 109

Death's Duell 27-29

Denby, Basil, Earl of, dedication to

Devotions 39-46

Doncaster, Lord, letters from $8_{3}$ verses to 108

Done, John, works by $151-153$

Donne, John, D.C.L. $1+5-150$

Biathanatos edited by $6 z-65$

Essays in Dirinity edited by 69-7

Ignutius his Conclave edited by 9, $54-56$ Juvenilia edited by $50,51,54-5^{-1}$

Letters edited by $73-7+$

letters from $62-63$

Poems edited by 106, 117

Sermons edited by 19

Tobie Matthew collection edited b: -j. 82,86

Truenty-six sermons published by $3_{2}-3^{3}$

Dorset, Earl of, letter to, with Derotions + 1

Doser, Earl of, decication to 152

Dowden, Edward, article by $13 \mathrm{~S}$ iibrary of $\mathrm{s}, 105$

Dowland, John, verses by 1 I 9

Droeshout, Martin, engraving by z8, 158

Drummond of Hawthornden, Corrererstions reith Ben Jonson 140

Drury, Elizabeth 95-101

Drury House, letter from Donne at $s .8$

Drury, Sir Robert, letter to 77

Dum premor, attollor, motto on derice 37

Duncan, A., engraving by $15 \mathrm{~S}$

Dunch, Mrs Bridget, dedieation to $7+$

Dunne, Mr S. G. 62

Dutch, translations into $+1,106,119-120$

Dyce collection, portrait in 157

Ecclesiastes, xii. 1, sermon on (Sapientia C\%mi tans) 31

Eulinburgh Magazine, article in 138

Effigies Poeticae, portrait in 158

Egerton, Sir Thomas, letters to 87

Eighty Sermons $33-3+$

Elizabeth, Queen, verses ascribed to 115

Ellesmerc, lord, library of $9^{6}$

Emmanuel College, Cambridere 6, 24, 32 , it, $35,54,65,118,152$

Encinila 22

Epigrams, Ben Jonson's 56

Epigrams, Donne's 50

Essays in Divinity 50, 67-70

Estienne, copy of derice used by 54 
F., Sir G., letter to 76

Ferris, S. J., etching by $\mathbf{I} 24$

Fitty sermons 34

Fish, Henry C., History and Repository of Pulpit Eloquence 33

Fitzherbert, Thomas, reply to Pseudo-martyr 4

Five sermons upon speciall occasions 25

Fleete, letters from Donne with the 87

Fortnightly Revieal, article in 138,139

Foure sermons upon speciall occasions 24

Fuller Worthies Library 123

Furst, Clyde, essay by 139

Gammon, James, engraving by $8 z$

Garet, Garrard, see Gerrard

Genesis, i. 26, two sermons on 31

Gerrard, George, letters to $7+-81,86$, I3 4

Gerrard, Mrs Martha, letter to 75

Gherard, see Gerrard

Godolphin, Sidney, elegy by 115

Gonville and Caius College, Cambridge 6, I 3 , I I 8

Goodere, see Goodyer

Goodyer, Sir Henry, letters to $75-81,86$, 88 , II I

$$
\text { verses to } 108
$$

Gordon, Mr Cosmo, library of $119, \quad 121$

Gosse, Mr Edmund, article by 138 essay on Death's Duel ${ }_{13} \mathrm{~S}$

library of $6,15,21,23,24,25,26,28$, $34,35,37,4+, 54,57,65,70$, So, 84 , $85,98,113,116,118,119,153,156$

Life and Letters edited by 139

Gossip in a Library, by Edmund Gosse 138

Grierson, Prof. H. J. C., essay by 1 to Letters, projected edition of 73 Poems edited by 125

Grolier Club Catalogue +9 Poems published by 123

Grosart, Dr A. B., his copy of Biathanatos $6 \hat{j}$ Poems edited by 123

Grove, Robert, Papismus Regiae Potestatis Eversor 16

Grymes, The Lady, letter to 78, 114

Gryphius, copy of device used by 29

$\mathrm{H}$., F., letter to 78

H., G., letter to 78

Haines, $\mathrm{Mr} 88$

Hall, Joseph 95

Hamilton, Marquess, verses to 109

Hanau, Conclave Ignati printed at 12

Harbert, Lord Philip, see Herbert

Harington, Sir John, letter to 76

Harrison, J. S., references by $1+0$
Harvard University, library of 117

Hastings, George, letter to 76

Hay, Lord, letters to $8_{3}, 8_{4}$

Heber Library Catalogue 63

Henry, Prince of Wales, elegy on 92, 109

Herbert, Edward, Lord, of Cherbury, letter to 75

MS. of Biathanatos presented to 62 verses to ro 8

Herbert, George, commemorations of the Lady

Danvers by 26

latin verses by II 7

letters written by 84

verses to I I 7

Walton's Life of $8_{4}-85$

Herbert, Sir Henry, Juvenilia licensed by 49 , 52

Pocms licensed by $105-106$

Herbert, Magdalen, letters to 85

verses to $\mathrm{I} 08$

Herbert, Philip, Lord, dedication to 65

Hilliard, Nicholas, portrait by 1 I 3

History of the Septuagint 152-153

Hodgson's, books sold at 98

Hoe Library 98, 100

Holbrooke, F., portrait in possession of 38,158

Holl, W., engraving by 38,158

Hollar, Wenceslaus, engraving by 158

Holme, Mr Strachan 96

Holt, Sir Robert, dedication to 132

Hosea, ii. 19, sermon on 31

Huntingdon, Countess of, verses to 108, I14

Hutchinson, Rev. F. E., article by $1 \neq 0$

Huth Library 98

Huyghens, Sir Constantine, Biathanatos presented to 63 translations by $+1,106,119-120$

Hyde, Edward, elegy by 28 , iा I

Iconography of Donne 157-158

Ignatius his Conclave $7-16,56$

Isaiah, l. I, sermon on 25

Italian inscription used by Donne 155

Jackson, Thomas, Dean of Peterborough, sermons by 32

James I, dedication to 3,25

Jameson, Mrs A. M., article by 137

Janssen, Cornelius, portrait ascribed to 157

Jessopp, Dr Augustus, Essays in Divinity edited by 70

Life by 139

note on John Done 150

Jesuits, apology for $11-16$ preface addressed to 6 
Jesus College, Cambridge $26,28,31,54,118$, 153

John, v. 22, sermon on 31

viii. 15 , sermon on $3 \mathrm{I}$

x. 22, sermon on (Encania) 23

John Rylands Library, Manchester 5+, 66, I 3

Johnson, Samuel, English poets 122

Lives of the Poets 137

Jonson, Ben, Conversations with Drummond of

Hawthornden 1 to

letter from $8_{3}$

lines by $55-57,117$, II 8

Underwoods i i 1

verses to 9I, I1 4,117

Volpone 91

H'orks 92

Judges, $r .20$, sermon on $2 \mathrm{I}$

$\mathrm{xx}$. 15 , sermon on $2 \mathrm{:}$

Juvenilia $+7-57$

Keeble, Richard, address to 35

Ker, Sir Robert, letters to $+1,75-80,83$

MS. of Biathanatos presented to 62

proofs of Deriotions sent to +1

Keynes, Mr G. L., library of $6,22,23,25$, $29,31,34,35,38,+4,54,56,66,70,80,84$, 100, II 3, I 18, II $9,132,153$

Keynes, Mr J. M., library of $34,35,66,80$

King, Alice, article by i 38

King, Henry, elegy by $28,111,132$

King's College, Cambridge $14,34,35,66,119$

Kingsmell, Lady, Biathanatos presented to 62 letters to $75,8 \mathbf{1}, 82$

Kinsmoll, The Rt Hon. the, see Kingsmell, Lady

L., $\mathrm{Mr} \mathrm{T}$., verses to 108

Lachryme Lachrymarum, Sylvester's 92

Lawyer's Philosophy, Tisdale's 156

Lee, $\mathrm{Mr}$, letter to, from John Donne, jun. 62

Leile, John, address to 35

Leisure Hour, article in ${ }_{1} 38$

Letters, Donne's 7i-88

Letters to several persons of honour $74-80$

Library, books from Donne's 154-155

Lightfoot, Dr J. B., article by 138

Lincoln Cathedral Library 28, 3:, 34, 44, 54, $66,1 \times 3$

Lincoln's Inn, sermon preached at 22

Llewellyn, M., Men-Miracles 120

Lombart, Pieter, engraving by $7+, 158$

Loseley MSS., letters from 86-88

Lothersley, see Loseley

Lowell, J. R., Poems edited by 123
Loyola, Ignatius it

Lucy, Sir Thomas, letters to 75,77

McKerrow's Printers' and Publishers Devices $29,3+, 37,54,152$

Macleane, Douglas, Famous Sirmous by English Preachers it

Maestricht, letter from Donne at 87

Magdalene College, Cambridge 6, 66, 80, 115

Marckham, J., Biathanatios presented to 63

Marckham, Lady, elegy on 107

Marion Press, Poems printed by $12+$

Marshall, William, engrarings by $+5,113$, I $57-158$

Marten, Sir Henry, letter to 88

Natthew, xxi. 6+, sermon on 31

Natthew, Sir Tobic, Collection of letters 73 , $82-8+, 86$

letter to $s_{+}$

Mayne, Jasper, D.D. $50,5+$

Mayne, Mr, elegy by $1: 2$

Melton, W. F., essay by 1 to

Merian, M., engraving by 33, 158

Merrill, C. S., Letters edited by 88

Merton, Mr Wilfred, MSS. in possession of 19,105

Merton College, Oxford $23,26,31,34,35$, 66,119

Meynell, Mr Everard, book offered by 155

Micham, letters from Domne at 75-80

Milbourne, William, sermons published by $; 2$

Minto, W., article by 1,38

Modern Language Reviere, article in $\mathrm{I}+\mathrm{I}$

Montgomery, Countess of, letter to 75

Moore, Rev. Charles, a refutation of Biathammos by 63

More, Sir George, letters to $76,86-87$

Nore, Sir Robert, letters to $87-88$

Morhof, D. G., Poly'isior +1, 120,137

Moseley, Humphrey, advertises Efigrams 50

Mother, Donne's, letter to \&3

Nation, article in $\mathrm{i}+1$

National Revieri, article in 139

New College, Oxford 6, 3t, 35

$N_{i}$ ee Revipat, article in 1,8

Nere Horld, article in 139

Newport, Francis, Lord, dedication to is

Ninetrent/s Cesturr, article in 138

Norton, C. E., article by 1 is Pooms annotated by 1:3

Notes amet Quaries, articles in 139. 1.t

Oliver, Isaac, miniature by $123,15^{8}$

Overbury, Sir Thomas, cikaraters 92 
Oxford, Devotions published at 46

MSS. preserved at $32,51,62,75,88,151$

Poems published at 125

Selections published at 122

Palatine, Count, verses on 108

Paradoxes, Problems, Essays 54-57

Paris, letters from Donne at $76,78,79$

Parker, Samuel, Imprimatur signed by $8_{5}$

Parsons, see Persons

Pearson, Mr John, library of 98

Peckham, letter from Donne at 77

Pembroke and Ruddier, Poems by 114,148

Pembroke College, Cambridge $22,23,24,25$, $29,31,45$, I I 8

Walton's copies of sermons in 20

Pembroke, Earl of, poems by 114

Pepys library 66, 119

Persons, Robert, The Judgment of a Catholike Englishman 4

2 Peter, iii. I 3 , sermon on 26

Peterborough Cathedral Library I5, 34

Peterhouse, Cambridge $3+$

Phillips, Edward, Theatrum Poetarum 137

Pickering, William, Devotions published by 46

Pickering and Chatto, books offered by 37 , $15+$

Poems, Collected 103-125

Poems, MSS. of 105

Poetry and Drama, article in 141

Polyitoron 152

Polyhistor, Morhof's 41, 120, 137

Pope, Alexander, Work's I 21

Porter, Endymion, epitaph by 112

Printers, 1607-1719, see p. 161

Printers' and Publishers' Devices, McKerrow's

$29,34,37,54,152$

Psalm xi. 3 , sermon on 24

lxviii. 20, sermon on (Deatb's duell) 28

Pseudo-martyr $\quad 1-6$

Publishers, 1607-1719, see p. 161

Puttick and Simpson's, letters sold at 73

Pyrford, letters from Donne at 78

Quarterly Review, articles in $\mathbf{I} 39$

Queens' College, Cambridge 6

Raleigh, Sir Walter, problem concerning $5^{1}$

Riche, Mrs Essex, verses to 108

Richter, Rudolph, essay by 139

Riverside Press, Poems printed by 124

Rochester, Lord, letters to 79,83

Roe, Sir John, poems by 114,119

Roe, Sir Thomas, letters to $75,78,88$

verses to $\mathbf{I} 14$
Rushworth, John, Imprimatur signed by 65

St Catharine's College, Cambridge 66

St John's College, Cambridge 6, 23, 24, 26, $28,34,45,54,65,80,113,116,118,119$

St John's College, Oxíord 6, 66, 113

St Paul's Cathedral, effigy in 157

Deanery, letters from Donne at 88

portrait at 157

Saintsbury, George, introduction by ' 124

Salisbury Cathedral library $6,16,34,80$

Salisbury, Countess of, verses to 108

Sanders, H. M., article by 139

Sanford, Ezekiel, Poems edited by 122

Sapientia Clamitans 31

Satyr, Donile's I 49

Savoy, letter from Donne at his lodging in the 86,88

Sayle, Mr C., library of 121

Schoff, S. A., engraving by 122

Sermons, Donne's 17-38

Shakespeare, epitaph on 109

Shakespearean miscellany, ed. Waldron I 21

Simeon, Sir John, poems printed by 123

Simpson, Rev. S., MS. in possession of 88

Simson, G., device used by 34

Six sermons upon severall oicasions $29-3 \mathbf{1}$

Skelton, engraving by 158

Sinyth, Sir Nicholas, verses to 119

Somerset, Earl of, letters to 79,83

Sotheby's, books sold at 98

Southey, Robert, Poems edited by 122

Spa, letter from Donne at 79

Spanish, Donne's use of $6,77,113$

Spearing, Miss E. M., articles by 140, 141 note by 19

Star Chamber, Board of the 49

Stationers' Hall registers $105-106$

Stephen, Sir Leslie, article by 139

Stone, Nicholas, effigy by 157

Strand, letters from Donne at his lodging in the 75,76

Suicide, $A$ full enquiry into the subject of; by Rev. Charles Moore $6_{3}$

Suicide, Donne's essay on 59-66

Sylvester, Joshua, Lachryme Lachrymarum 92

Symons, Arthur, article by 139

Talboys, D. A., Devotions published by ${ }_{4} 6$ Selections published by 122

Temple Bar, article in 139

Theatrum Poetarum 137

Thompson, Mrs K. B., article by 138

Three sermons upon speciall occasions 23 


\section{Index}

Tilman, Mr, verses to 1 I 5

Times Literary Supplement, article in 141

Tisdale, Roger, dedication to Donne 156

Tomlins, T. E., Walton's Life edited by 133

Tregaskis, Mr, books offered by 155

Trinity College, Cambridge $6,23,24,28,31$, $34,42,45,54,56,66,70,80,1 I_{3}$, I 16 , I $19,121,132$, I 50

Trost, Wilhelm, essay by i to

Tupling, John, Essavs in Divinity published by 70

Tutin, J. R., Selected Poems published by 124 Twenty-six sermons $35-38$

Underwoods, Ben Jonson's i I I

University Library, Cambridge, books in the $6,12,14,15,22,23,25,26,31,32,34,35$, $37,42,44,54,65,84,85,86,113,115,121$, 152,153

Valentine, Henry, elegy by i I

Vandyke, portrait attributed to 38,158

Victoria and Albert Museum, portrait at 157

Virginian Plantation, sermon preached to Honourable Company of the 22,23

Volpone, Ben Jonson's 9 I

Waldron, F. G., poems printed by 12 I Walton, Canon Izaak, autograph of 80
Walton, Izaak, autograph of $20,29,31,3+, 80$ Compleat Angler 109

elegy by in

Lite of Donne $33,+6, \quad 127-133$

Life of Herbert $8_{4}-8_{5}$

verses by 113

verses to $8_{3}$

Warner, Rebecca, Epistolury Curiositics 109

White, R., engraving by ' 5

White, Mr IV. A., library of it

White, Mrs Bridret, letters to 75

Whitehall, sermon preached at 25

Whitlock, Bolstred, address to 35

Will, Donne's I 50

Wilson, Arthur, clegy by i 12

Wistome crying out to Sinners (Sifientia Clami tans) 32

W'it and Drollery I I 9

Wolf, Henry, wood engraving by 124

Woodforde, Samuel, verses by $\$ 5$

Woodward, Rowland, Pseudo-marty presented to 6 verses to 108

Woodward, Thomas, verses to 108

Worcester Cathedral library 34, 35. 37

Wotton, Sir Henry, letters to 76,77 verses to $107,10 \mathrm{~S}$

Zouch, Thomas, Walton's Live's edited by i;0 


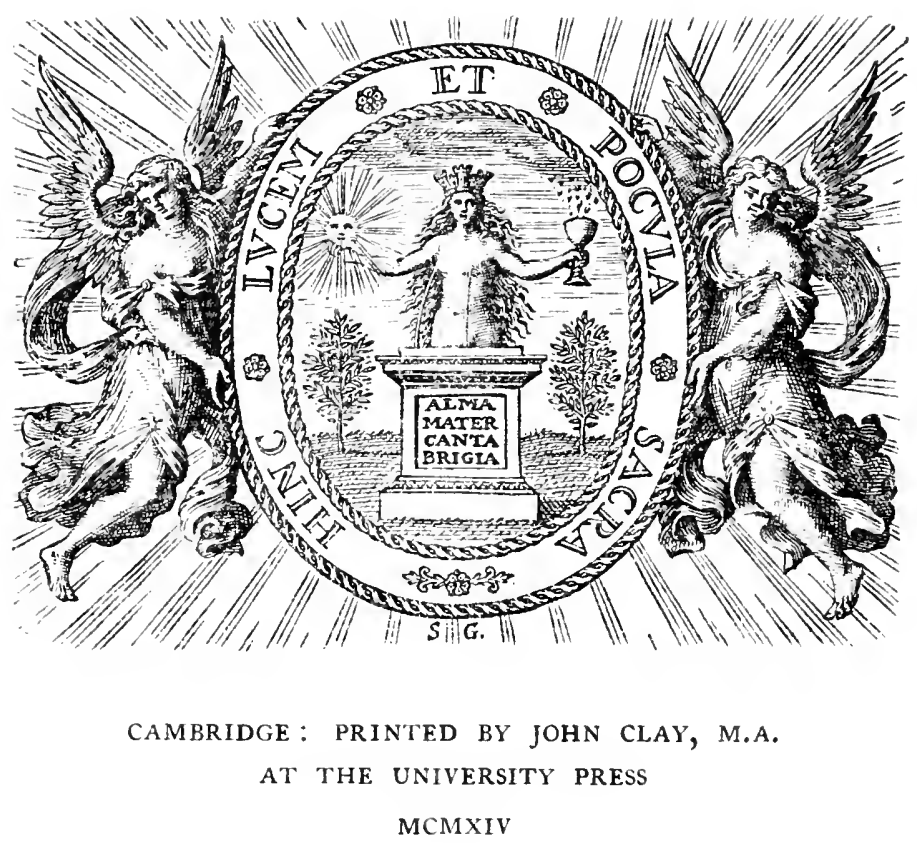





. 
AA $001168299 \quad 4$ 
